\title{
EFFECTS OF AGRICULTURAL LAND-MANAGEMENT PRACTICES ON WATER QUALITY IN NORTHEASTERN GUILFORD COUNTY, NORTH CAROLINA, 1985-90
}

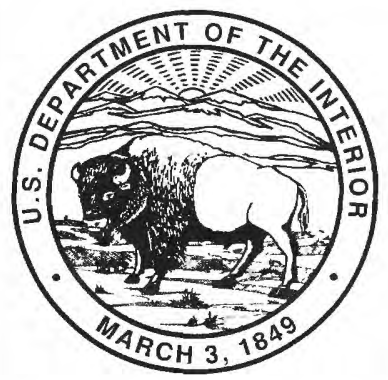

U.S. GEOLOGICAL SURVEY WATER-SUPPLY PAPER 2435

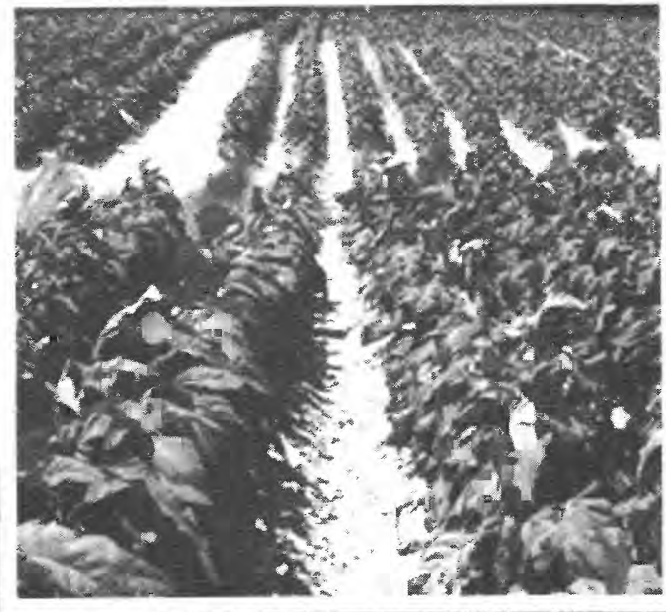

Prepared in cooperation with the GUILFORD COUNTY SOIL AND WATER CONSERYATION DISTRICT 
Cover Photograph. Tobacco field in Guilford County, N.C., farmed by using the standard land-management practice of tillage without regard to land contours. 


\section{Effects of Agricultural Land-Management Practices on Water Quality in Northeastern Guilford County, North Carolina, 1985-90}

\section{By DOUGLAS A. HARNED}

Prepared in cooperation with the Guilford County

Soil and Water Conservation District 


\title{
U.S. DEPARTMENT OF THE INTERIOR BRUCE BABBITT, Secretary
}

\author{
U.S. GEOLOGICAL SURVEY \\ GORDON P. EATON, Director
}

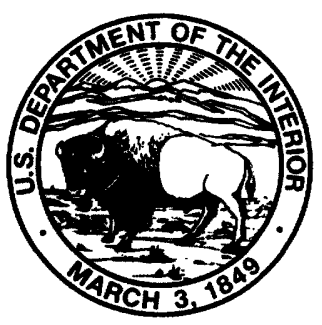

Any use of trade, product, or firm names in this publication is for descriptive purposes only and does not imply endorsement by the U.S. Government.

Printed in the Eastern Region, Reston, Va.

For sale by the U.S. Geological Survey Information Services Box 25286, Federal Center Denver, CO 80225

\section{Library of Congress Cataloging in Publication Data}

Harned, Douglas.

Effects of agricultural land-management practices on water quality in northeastern Guilford County, North Carolina, 1985-90 / by Douglas A. Harned.

p. $\quad \mathrm{cm}$. - (U.S. Geological Survey water-supply paper ; 2435)

"Prepared in cooperation with the Guilford County Soil and Water Conservation District."

Includes bibliographical references.

Supt. of Docs. no.: 119.13:2435

1. Agricultural pollution-North Carolina-Guilford County. 2. Water qualityNorth Carolina-Guilford County. I. Guilford County Soil and Water Conservation District (N.C.) II. Title. III. Series. TD428.A37H37 1995 


\section{CONTENTS}

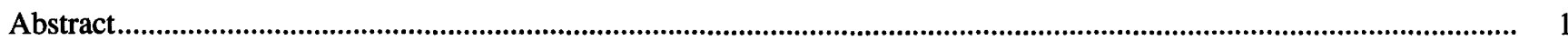

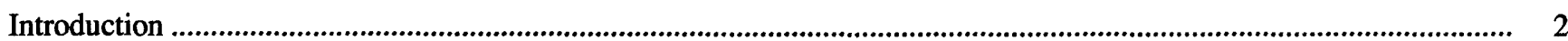

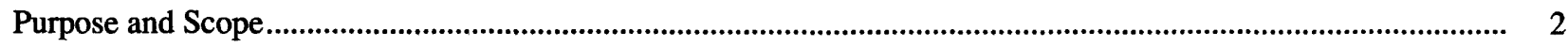

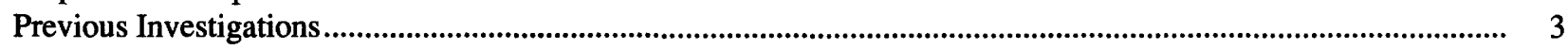

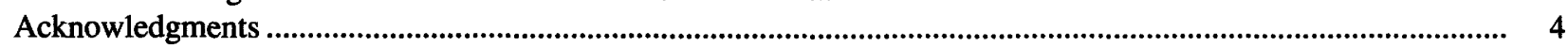

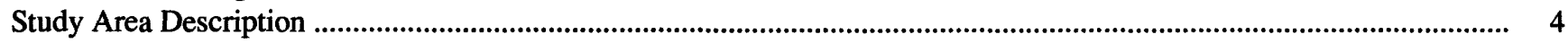

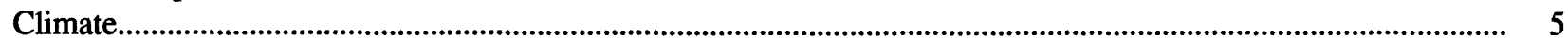

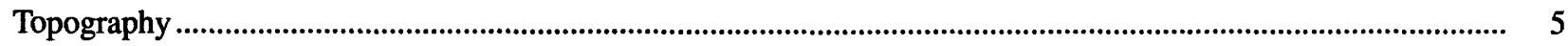

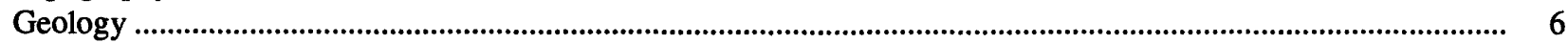

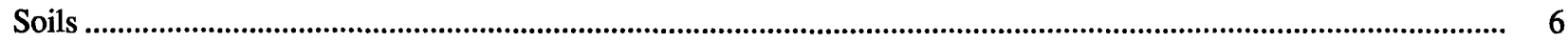

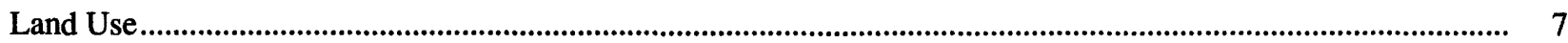

Land-Management Practices ..................................................................................................................................... 7

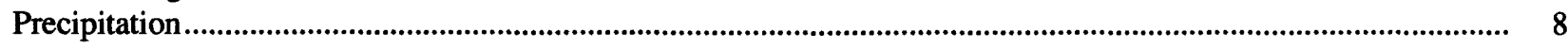

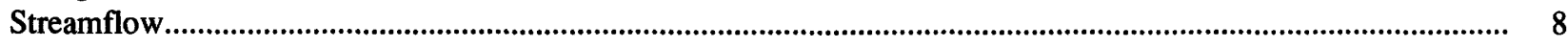

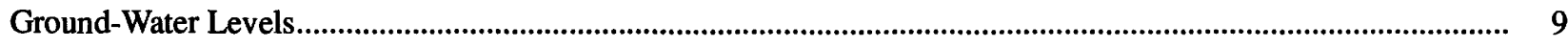

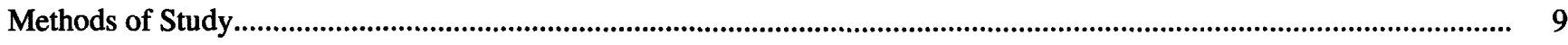

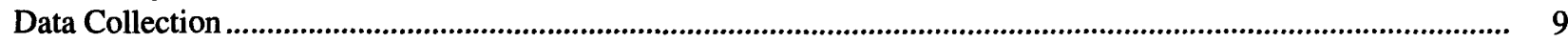

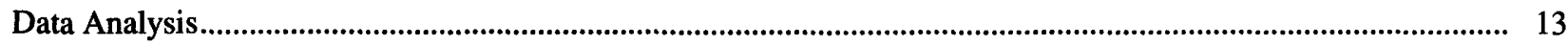

Effects of Land Use and Land-Management Practices on Streamflow ............................................................................. 14

Effects of Land Use and Land-Management Practices on Water Quality .......................................................................... 15

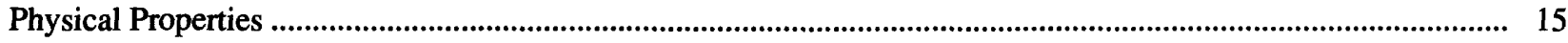

$\mathrm{pH}$

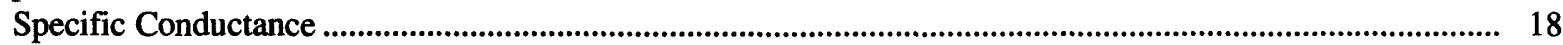

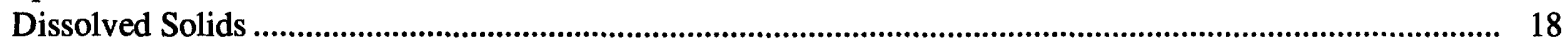

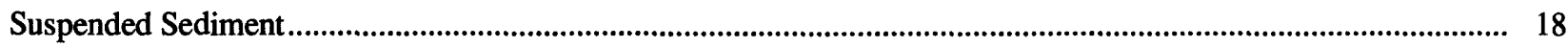

Suspended-Sediment Concentrations .................................................................................................. 19

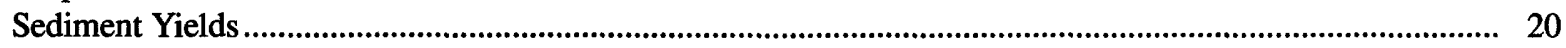

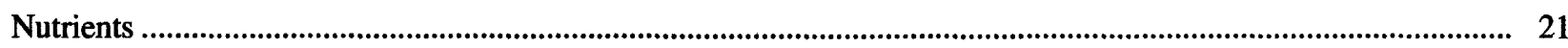

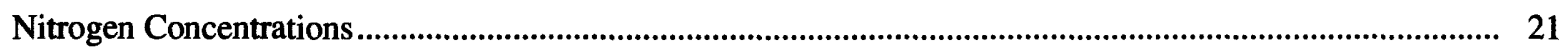

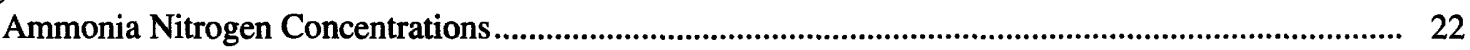

Total Ammonia and Organic Nitrogen Concentrations .............................................................. 22

Total Nitrite Plus Nitrate Concentrations ........................................................................................ 27

Total Nitrogen Concentrations................................................................................................................. 28

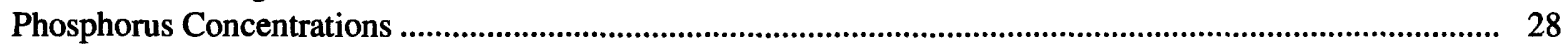

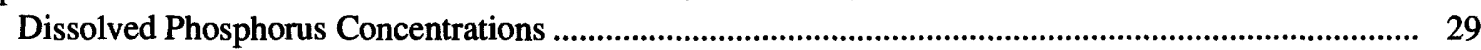

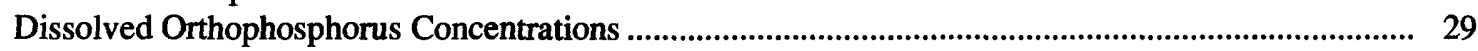

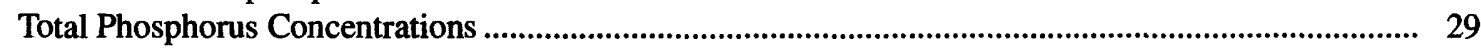

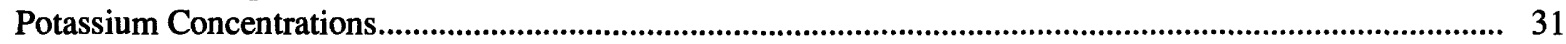

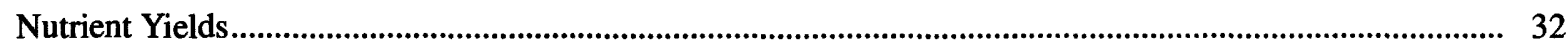

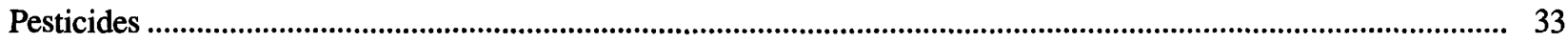

Pesticide Concentrations in Surface Water.......................................................................................... 33

Pesticide Concentrations in Ground Water and Soil in the Row-Crop Basins .............................................. 34

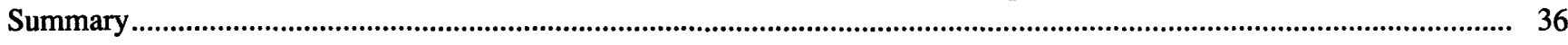

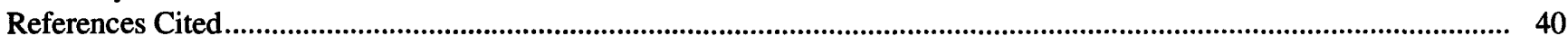




\section{APPENDIXES}

1. Log of farming activities at the row-crop basins, 1984-90, Guilford County, North Carolina .

2A-F. Log of chemical and fertilizer applications at the row-crop basins in Guilford County, North Carolina in-

2A. 1985

2B. 1986

2C. 1987

2D. 1988

2E. 1989

2F. 1990

3. Probability levels for the Wilcoxon ranked sum test comparisons between distributions of physical water-quality properties measured in surface water at the four study basins and precipitation at station 1

4-7. Probability levels for the Wilcoxon ranked sum test comparisons between distributions of nutrients measured in-

4. Surface water at the four study basins and precipitation at station 1

5. Ground water and soil water at the two row-crop basins

6. Surface water at the two row-crop basins and nutrients measured in ground water and soil water at the two row-crop basins

7. Soil-water samples from lysimeters at 3-, 6-, and 9-foot depths at the two row-crop basins

8-18. Pesticide concentrations in-

8. Surface water at the forested basin

9. Surface water at the mixed land-use basin

10. Surface water at the standard land-management practices basin

11. Surface water at the conservation land-management practices basin

12. Ground water from well 101 and soil samples nearby, conservation land-management practices basin.......

13. Soil samples at well 103 , conservation land-management practices basin

14. Soil samples at well 201 , standard land-management practices basin

15. Soil samples at well 206 , standard land-management practices basin

16. Soil water at a depth of 6 feet and soil at well 208, standard land-management practices basin

17. Ground water from well 107 , conservation land-management practices basin.

18. Ground water from well 209 , standard land-management practices basin

19-21. Probability levels for the Wilcoxon ranked sum test comparisons between distributions of pesticide concentrations measured in-

19. Surface water at the four study basins and soil at 3-, 6-, and 9-inch depths at the two row-crop basins.......

20. Surface water and soil at all depths at the two row-crop basins.

21. Soil at 3-, 6-, and 9-inch depths at the two row-crop basins

\section{FIGURES}

1. Map showing location of study basins in the Piedmont of North Carolina

2. Graph showing mean seasonal precipitation at the two precipitation stations and mean seasonal streamflow during nongrowing and growing seasons at the four study basins.

3, 4. Maps showing-

3. Potentiometric surface on August 15, 1986, and March 31, 1986, at the two row-crop basins

4. Land-surface altitudes and locations of wells, stream gages, precipitation stations, and intermittent streams in the row-crop basins

5. Hydrogeologic sections $A-A^{\prime}$ at the standard land-management practices basin and $B-B^{\prime}$ at the conservation land-management practices basin

6. Box plots showing summary of $\mathrm{A}, \mathrm{pH} ; \mathrm{B}$, specific conductance; C, dissolved-solids concentrations; and $\mathrm{D}$, suspended-sediment concentrations in surface and ground water and in precipitation. 
7-9. Graphs showing-

7. Yields of suspended sediment in surface water at the four study basins.

8. Distribution of fertilizer and lime applications, by month, at the two row-crop basins

9. Percentage of fertilizer and lime applications at the standard land-management practices basin, at the conservation land-management practices basin, and at both basins.

10-14. Box plots showing summary of-

10. A and B, total ammonia nitrogen concentrations and, $\mathrm{C}$ and $\mathrm{D}$, total ammonia and organic nitrogen concentrations in surface water, soil water, and ground water and in precipitation.

11. A and B, total nitrite plus nitrate concentrations and, C and D, total nitrogen concentrations in surface water, soil water, and ground water and in precipitation.

12. A, dissolved phosphorus concentrations and, $B$ and $C$, dissolved orthophosphorus concentrations in surface water, soil water, and ground water and in precipitation

13. Total phosphorus concentrations in surface water, soil water, and ground water and in precipitation ............ 31

14. Total potassium concentrations in surface water at the four study basins.................................................... 32

15-20. Graphs showing-

15. Yields of total nitrogen in surface water at the four study basins

16. Yields of total phosphorus in surface water at the four study basins

17. Distribution of principal pesticide applications, by month, at the two row-crop basins.....

18. Percentage of pesticide applications at the standard land-management practices basin, at the conservation land-management practices basin, and at both basins

19. Percentage of surface-water samples with detectable concentrations of monitored pesticides in the four study basins

20. Percentage of surface-water, soil, and ground-water samples with detectable concentrations of the pesticides acephate, ethoprop, metalaxyl, diphenamid, isopropalin, fenamiphos, flumetralin, and napropamide in the two row-crop basins

\section{TABLES}

1. Study basin characteristics, Guilford County, North Carolina.

2. Approximate percentage of major land uses in the North Carolina Piedmont, the Haw River basin, and the mixed land-use Candy Creek study basin

3. Percentage, by year, of land use and crop type for the mixed land-use basin.

4. Streamflow characteristics at the four study basins .

5. Summary of data-collection frequencies at the four study basins.

6. Summary of well-construction characteristics

7-9. Summary statistics for-

7. Physical water-quality properties of surface water in the four study basins and of precipitation at station 1

8. Specific conductance and $\mathrm{pH}$ in samples collected from wells 209 and 107 in the row-crop basins

9. Suspended sediment in surface water at the four study basins

10. Yields of total suspended sediment and nutrients in surface water at the four study basins.

11-13. Summary of analyses of the major plant nutrients in-

11. Surface-water and precipitation samples collected from the four study basins.

12. Ground-water samples collected from wells and soil-water samples collected from lysimeters in the row-crop basins....

13. Soil-water samples collected from lysimeters at 3-, 6-, and 9-foot depths in the row-crop basins

Summary of the number of surface-water samples with detectable concentrations of monitored pesticides in the four study basins

5. Summary of the number of soil and ground-water samples with detectable concentrations of monitored pesticides in the two row-crop basins 
CONVERSION FACTORS, VERTICAL DATUM, AND TEMPERATURE

\begin{tabular}{rcl}
\hline Multiply & By & To obtain \\
\hline inch (in.) & Length & \\
foot (ft) & 25.4 & millimeter \\
mile (mi) & 0.3048 & meter \\
& 1.609 & kilometer \\
\hline acre & Area & \\
& 4,047 & square meter \\
& 0.4047 & hectare \\
square mile (mi $\left.{ }^{2}\right)$ & 2.590 & square kilometer \\
\hline & Volume & liter \\
\hline pint (pt) & 0.4732 & liter \\
quart (qt) & 0.9464 & liter \\
gallon (gal) & 3.785 & kilogram \\
\hline & Mass & megagram \\
\hline pound, avoirdupois (lb) & 0.4536 & kilogram per hectare \\
\hline ton, short $(2,000 ~ l b)$ & 0.9072 & cubic meter per second \\
\hline
\end{tabular}

Sea level: In this report "sea level" refers to the National Geodetic Vertical Datum of 1929

(NGVD)_a geodetic datum derived from a general adjustment of the first-order level nets of both the United States and Canada, formerly called Sea Level Datum of 1929.

Temperature: In this report temperature is given in degrees Celsius $\left({ }^{\circ} \mathrm{C}\right)$, which can be converted to degrees Fahrenheit $\left({ }^{\circ} \mathrm{F}\right)$ by the following equation:

$$
{ }^{\circ} \mathrm{F}=1.8\left({ }^{\circ} \mathrm{C}\right)+32
$$




\title{
Effects of Agricultural Land-Management Practices on Water Quality in Northeastern Guilford County, North Carolina, 1985-90
}

\author{
By Douglas A. Harned
}

\section{Abstract}

The effects of selected agricultural landmanagement practices on water quality were assessed in a comparative study of four small basins in the Piedmont province of North Carolina. Agricultural practices, such as tillage and applications of fertilizer and pesticides, are major sources of sediment, nutrients, and pesticides in surface water, and of nutrients and pesticides in ground water.

The four study basins included two adjacent row-crop fields, a mixed land-use basin, and a forested basin. One of the row-crop fields ( 7.4 acres) was farmed by using conservation landmanagement (CLM) practices, which included strip cropping, contour plowing, field borders, and grassed waterways. The other row-crop field (4.8 acres) was farmed by using standard landmanagement (SLM) practices, which included continuous cropping, straight-row plowing without regard to land topography, and poorly maintained waterways. The mixed land-use basin ( 665 acres) was monitored to compare water quality in surface water as SLM practices were converted to CLM practices during the project. The forested basin (44 acres) provided background surfacewater hydrologic and chemical-quality conditions.

Surface-water flow was reduced by 18 percent by CLM practices compared to surface-water flow from the SLM practices basin. The thickness of the unsaturated zone in the row-crop basins ranged from a few feet to 25 feet. Areas with thick unsaturated zones have a greater capacity to inter- cept and store nutrients and pesticides than do areas with thinner zones.

Sediment concentrations and yields for the SLM practices basin were considerably higher than those for the other basins. The median sediment concentration in surface water for the SLM basin was 3.4 times that of the CLM basin, 8.2 times that of the mixed land-use basin, and 38.4 times that of the forested basin. The total sediment yield for the SLM basin was 2.3 times that observed for the CLM basin, 14.1 times that observed for the mixed land-use basin, and 19.5 times the yield observed for the forested basin.

Nutrient concentrations in surface water from the row-crop and mixed land-use basins were higher than those measured in the forested basin and in precipitation collected near the rowcrop basins. The SLM basin generally had the highest concentrations of total nitrogen, nitrite plus nitrate, total phosphorus (equivalent to the mixed land-use basin), and potassium.

Nutrient concentrations in soil water and ground water were less than concentrations in surface water for the row-crop basins. Nutrient concentrations generally were least slightly below the root zone (3-foot depth) and in ground water.

Differences in nutrient yields among basins had patterns similar to those observed for nutrient concentrations. The total nitrogen yield for the SLM basin was 1.2 times the yield for the CLM basin, 1.9 times the yield for the mixed land-use basin, and 4.2 times the yield for the forested basin. The total phosphorus yield for the SLM basin was 1.7 times the yield for the CLM basin, 
3.3 times the yield for the mixed land-use basin, and 7.8 times the yield for the forested basin.

No significant differences in pesticide concentrations in surface water were identified between those measured in the SLM basin and those measured in the CLM basin. Significantly higher pesticide concentrations were observed at the row-crop basins compared with those observed at the mixed land-use basin probably because sampling sites for the row-crop basins were closer to the pesticide sources. No pesticides were detected in the forested basin.

Comparisons of pesticide concentrations in soil from the two row-crop basins indicated some differences. Concentrations of the soil pesticides isopropalin and flumetralin were higher in the SLM basin than in the CLM basin.

The surface-water quality of the mixed land-use basin generally was less affected by agricultural nonpoint sources than that of the smaller row-crop basins. This probably reflects the effects of 13 small farm ponds in the mixed land-use basin that served as sediment, nutrient, and pesticide traps.

\section{INTRODUCTION}

Agricultural practices such as land tillage or fertilizer and pesticide application are major sources of sediment, nutrients, and pesticides in surface water and of nutrients and pesticides in ground water. The extent, however, to which agricultural practices serve as nonpoint sources of contamination is largely a function of how the agricultural land is managed.

Farmers can use land-management practices to reduce erosion, increase soil moisture, and reduce the transport of farm chemicals and fertilizer in surface water from fields. These methods, generally referred to as CLM practices, include development of grassed waterways and field borders, strip cropping, contour plowing, and crop rotation. In contrast, when traditional or SLM practices are used, waterways commonly are poorly maintained, crop production generally is continuous and without rotation, and the rows are plowed straight without regard to slope or topography.

In 1984, the U.S. Geological Survey (USGS), in cooperation with the Guilford County Soil and Water
Conservation District, began a 6-year study of four small basins in the Piedmont province of North Carolina to better define how agricultural landmanagement practices affect water quality. The Piedmont physiographic province extends from New Jersey through Alabama and is characterized by clayey soils, rolling topography, and abundant rainfall. Study basins were selected in the Piedmont because of the highly erosive nature of the soils and the ongoing local effort to implement CLM practices on farmland in the area. The basins (fig. 1) include the Brooks Lake tributary basin ( 44 acres), referred to in this report as the forested basin; the Candy Creek basin (665 acres), referred to as the mixed land-use basin; the Smith Branch upper tributary basin (4.8 acres), referred to as the SLM practices basin; and the Smith Branch lower tributary basin (7.4 acres), referred to as the CLM practices basin. The two Smith Branch tributary basins are row-crop fields and together are referred to as the row-crop basins in this report. Results of this study are applicable to similar agricultural lands throughout the Piedmont physiographic region of the southeastern United States.

\section{Purpose and Scope}

This report describes the effects of different agricultural land-management practices on surfaceand ground-water quality in four small basins in northeastern Guilford County in the Piedmont of North Carolina. The surface-water data examined include discharge and nutrient, sediment, and pesticide concentrations in surface-water samples collected at four surface-water gaging stations, including one station in a forested basin, one in an area of mixed agricultural land use, one in a row-crop basin using SLM practices, and one in a row-crop basin using CLM practices.

Ground-water data examined include water levels and nutrient concentrations in ground-water samples collected from 18 wells in the row crop basins and nutrient concentrations in soil-water samples collected from 39 lysimeters installed in the unsaturated zone of the row-crop basins. Selected pesticides data for water samples from two wells and for soil samples from the row-crop basins also were examined. Chemical quality of precipitation was sampled at a site near the rowcrop basins. In addition, a log of agricultural activities recorded by the farmer for the row-crop basins was examined for this report. 


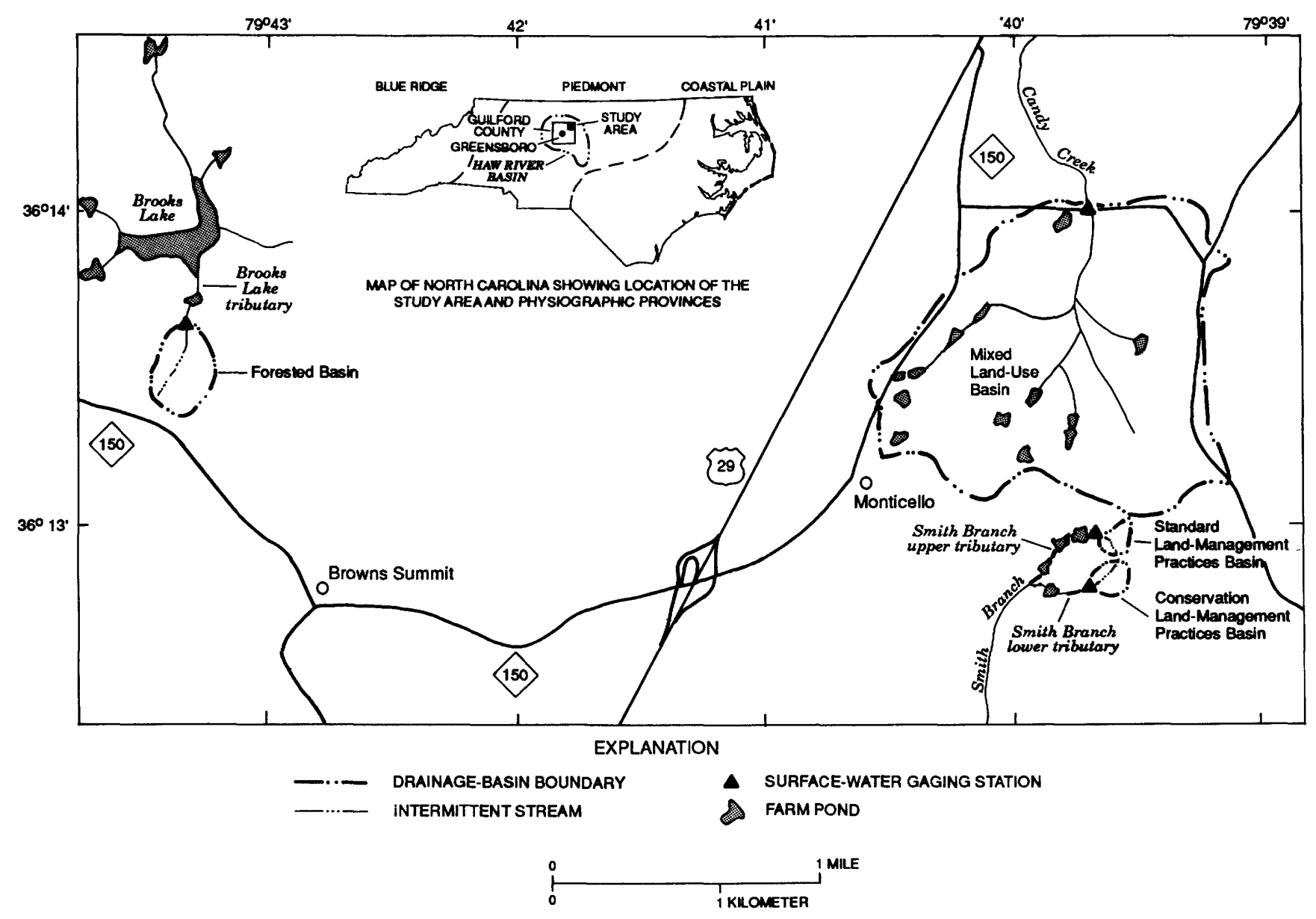

Figure 1. Location of study basins in the Piedmont of North Carolina.

The study design allowed comparisons of water quality among the four basins. The station in the forested basin served as a background station, where water quality is virtually unaffected by landmanagement practices. The row-crop basins were compared to detect any differences in water quality between SLM and CLM practices. The mixed land-use basin showed water-quality conditions for an area of larger scale.

The water-quality properties and constituents examined include streamflow, specific conductance, and $\mathrm{pH}$ and concentrations of potassium, nitrite plus nitrate nitrogen, ammonia and organic nitrogen, total nitrogen, total and dissolved phosphorus, orthophosphorus, and suspended sediment. Pesticides analyzed include acephate, ethoprop, metalaxyl, diphenamid, isopropalin, fenamiphos, flumetralin, and napropamide.

Data were collected from April 1985 through September 1990 . Surface-water quality data were collected quarterly and during selected storms. Ground- water samples for nutrient analyses were collected quarterly from two wells, and soil-water samples for nutrient analyses were collected weekly in the spring of each year from lysimeters. Ground-water and soil samples for pesticide analyses were collected biannually and during selected storms. Precipitation samples were collected five times per year.

\section{Previous Investigations}

Selected data and some of the results of this study have been published previously in two reports by Hill (1989 and 1991). In 1989, Hill published a description of the study area, 1984-88 data, and preliminary results. An analysis of sediment data collected from 1984 to 1988 was published in 1991.

This study employs paired basins with similar characteristics but differing land-management practices. This approach is cited as a particularly effective means of evaluating the water-quality effects of management practices (Spooner and others, 1985; 
National Water Quality Evaluation Project, 1989). Careful monitoring of hydrologic and meteorologic processes is required to separate effects of agricultural practices on water quality from effects of natural variation (Hirsch and others, 1982; Spooner, 1990).

Spooner and others (1989) reviewed a variety of assessments of water-quality effects of differing tillage practices. These studies emphasize the importance of regional variability in cropping practices, topography, and soil types on water quality. Although the information collected was site specific, the studies generally demonstrated reduced sediment and nutrient losses from basins in which conservation tillage or other conservation management practices, as compared to standard management practices, were used. Effects of conservation practices on pesticide concentrations in surface water and ground water are more variable than effects on sediment and nutrient concentrations; some practices have been noted to increase pesticide concentrations in surface water (Sauer and Daniel, 1987), whereas other practices have been shown to decrease pesticide concentrations in ground water (Donigian and Carsel, 1987). Pesticide concentrations in surface water and particularly in ground water are affected by a variety of chemical and physical reactions in the soil zone (Smith and others, 1988).

The effects of land-management practices on water quality in the Piedmont have not been studied extensively. Lanier and Hunt (1986) described a comparative study designed to demonstrate energy savings and water-quality benefits of CLM practices for Piedmont tobacco fields in Granville County, North Carolina. The differences between a control basin and the basin with conservation practices were substantial; however, the study was limited to 2 years, and a different control basin was used in the second year, thus complicating the comparison. Atkins (1984) described a study in Wake County, North Carolina, designed to compare the effects of soybean cropping on water quality using conservation versus standard management practices. The 18-month study examined surface-water sediment and nutrient concentrations, as well as economic impacts. The comparison between the basins demonstrated large reductions in sediment and nutrient yields resulting from conservation management practices, such as no-till farming, terraces, and farm ponds.

\section{Acknowledgments}

The author gratefully acknowledges the assistance of the staff of the Guilford County Soil and Water Conservation District and extends thanks to John W. Andrews, District Conservationist, in particular, who provided data related to land treatment, land use, and pesticide and fertilizer application in the study area. Special thanks are extended to the agricultural basin land owners, Larry W. and T.R. Spencer, who were extraordinarily cooperative and tolerant during the course of the study.

The original proposal for the study was written by C.E. Simmons. Cathy Hill was the project chief for the study from 1984-88, Chuck Barnes was chief for 1988 , and the author was chief from 1989-91. Water quality and quantity data were collected by Cathy Hill from 1985-88, by Lloyd Edwards in 1988, by Gary Garrett from 1988-89, and by Jerry Rinehardt, Karl Korfmacher, and the author from 1989-90. Elise Powell provided help with data compilation.

\section{STUDY AREA DESCRIPTION}

The study area lies within the Piedmont physiographic province. The Piedmont of North Carolina (fig. 1), as described by Fenneman (1938), is part of the Piedmont province that extends from New Jersey to Alabama and lies between the Blue Ridge and Coastal Plain provinces. The Piedmont of North Carolina has an area of approximately 20,000 square miles, which covers approximately 42 percent of the State.

The study area consists of four basins - two row-crop basins, a mixed land-use basin, and a forested basin-that are about 7 miles northeast of Greensboro in Guilford County, N.C. (fig. 1). The two row-crop basins drain to intermittent tributaries to Smith Branch near Monticello, N.C. The mixed land-use basin drains to Candy Creek near Monticello. The forested basin drains to a tributary to Brooks Lake near Browns Summit, N.C. The study basins are all part of the Haw River drainage area. A ummary of the basin characteristics is given in table 1 .

The basins were selected to minimize variation in physical characteristics among sites. The two rowcrop basins, part of the same family farm, are adjacent and similar in physical characteristics, including underlying geology and soils. All four basins are 
Table 1. Study basin characteristics, Guilford County, North Carolina

[Basin locations shown in figure 1]

\begin{tabular}{|c|c|c|c|c|}
\hline $\begin{array}{c}\text { Basin size } \\
\text { (acres) }\end{array}$ & $\begin{array}{l}\text { Slope of } \\
\text { principal } \\
\text { drainage } \\
\text { (percent) }\end{array}$ & Land use & Land-management practices & Soil types ${ }^{1}$ \\
\hline $4.8 \ldots \ldots . . . .$. & 2.3 & $\begin{array}{l}\text { Agricultural: } \\
\text { tobacco and } \\
\text { fescue. }\end{array}$ & $\begin{array}{l}\text { Continuous tobacco-small grain } \\
\text { cropping, up and down the row } \\
\text { slope; poorly maintained waterways. }\end{array}$ & $\begin{array}{l}\text { CeB2-Cecil sandy clay loam, } 2 \text { to } 6 \text { percent slopes, eroded. } \\
\text { CcC-Cecil sandy loam, } 6 \text { to } 10 \text { percent slopes. }\end{array}$ \\
\hline $7.4 \ldots \ldots \ldots . . .$. & 4.6 & $\begin{array}{l}\text { Agricultural: } \\
\text { tobacco, wheat, } \\
\text { and fescue. }\end{array}$ & $\begin{array}{l}\text { Strip cropping, crop rotation, contour } \\
\text { farming, field borders, grassed } \\
\text { waterways. }\end{array}$ & CeB2-Cecil sandy clay loam, 2 to 6 percent slopes, eroded. \\
\hline \multicolumn{5}{|c|}{ Mixed land-use basin-Candy Creek, near Monticello, N.C. $(0209331325)^{2}$} \\
\hline $665 \ldots \ldots \ldots$ & 1.5 & $\begin{array}{l}\text { Mixed: cropland, } \\
\text { woodland, } \\
\text { pasture, and } \\
\text { residential. }\end{array}$ & $\begin{array}{l}\text { Primarily continuous tobacco-small } \\
\text { grain cropping, up and down the } \\
\text { row slope; grassed waterways; some } \\
\text { conservation land management. }\end{array}$ & $\begin{array}{l}\text { ApC-Appling sandy loam, } 6 \text { to } 10 \text { percent slopes. ApB- } \\
\text { Appling sandy loam, } 2 \text { to } 6 \text { percent slopes. CeBZ-Cecil } \\
\text { sandy clay loam, } 2 \text { to } 6 \text { percent slopes, eroded. CeC2- } \\
\text { Cecil-sandy clay loam, } 6 \text { to } 10 \text { percent slopes, eroded. } \\
\text { CfB-Cecil-Urban land complex, } 2 \text { to } 10 \text { percent slopes. } \\
\text { Ch-Chewacla sandy loam. VaB-Vance sandy loam, } 2 \text { to } 6 \\
\text { percent slopes. VaC-Vance sandy loam, } 6 \text { to } 10 \text { percent } \\
\text { slopes. }\end{array}$ \\
\hline \multicolumn{5}{|c|}{ Forested basin-Brooks Lake tributary, near Browns Summit, N.C. $(0209330990)^{2}$} \\
\hline $44 \ldots \ldots \ldots . .$. & 4.1 & $\begin{array}{l}\text { Forested ( } 85 \text { per- } \\
\text { cent) and brush } \\
\text { (15 percent })\end{array}$ & Generally undisturbed. & $\begin{array}{l}\text { ApB-Appling sandy loam, } 2 \text { to } 6 \text { percent slopes. ApC- } \\
\text { Appling sandy loam, } 6 \text { to } 10 \text { percent slopes. MaE- } \\
\text { Madison sandy loam, } 15 \text { to } 35 \text { percent slopes. MaC- } \\
\text { Madison sandy loam, } 6 \text { to } 10 \text { percent slopes. }\end{array}$ \\
\hline
\end{tabular}

${ }^{1}$ U.S. Department of Agriculture, 1977.

${ }^{2}$ U.S. Geological Survey downstream order identification number.

within a 4-mile radius and have similar climatological and soil characteristics.

\section{Climate}

The North Carolina Piedmont lies within a humid, subtropical climate region. Mean annual temperatures range from 14 to $16^{\circ} \mathrm{C}$; January is generally the coldest month, and July is the hottest month (Eder and others, 1983). The growing season, which is defined as that period without damaging frosts, generally lasts from mid-April to the end of October, an average of about 200 days.

The average annual precipitation in the Piedmont of North Carolina ranges from 42 to 60 inches. Generally, the greatest monthly precipitation occurs during the summer months, and the least precipitation occurs in October or November. Although rainfall is heaviest in the summer, evaporation and transpiration losses also are greatest then; consequently, there is little ground-water recharge during this season.
Precipitation during the period of study was representative of the range of natural conditions. The average annual precipitation at the National Oceanic and Atmospheric Administration station at the Greensboro Regional Airport (1931-90) was 42.5 inches (National Oceanic and Atmospheric Administration, 1990). During the period of the study (198590 ), the average annual precipitation was 40.7 inches, and the annual precipitation ranged from 29.67 inches in 1986 to 50.64 inches in 1989.

\section{Topography}

The Piedmont consists of low, rounded hills and long, rolling northeast-trending ridges with as much as a few hundred feet of local relief. Land-surface altitudes increase from about 150 feet above sea level along the eastern boundary of the Piedmont to 1,900 feet along the western boundary at the foot of the Blue Ridge Mountains. 
The land-surface altitudes of the two row-crop basins range from approximately 810 to 835 feet above sea level. The altitudes range from 735 to 850 feet above sea level in the mixed land-use basin and from 740 to 835 feet above sea level in the forested basin.

The slope of the principal drainage for the study basins ranges from 4.6 percent for the CLM basin to 1.5 percent for the mixed land-use basin (table 1). The CLM basin slope (4.6 percent) is twice that of the SLM basin slope (2.3 percent).

\section{Geology}

The geology of the North Carolina Piedmont is complex; the bedrock consists of folded and fractured metamorphosed sedimentary and igneous basement rocks. Intruded into these metamorphic rocks are lesser bodies of unmetamorphosed igneous rocks. Typical bedrock lithologies include granite, gneiss, schist, quartzite, slate, and phyllite.

The study basins are underlain by intrusive rocks of the Charlotte belt and by metamorphic rocks of the Milton belt. Rocks of the forested basin are biotite gneiss and schist of the Milton belt. Bedrock in the other basins is granitic rock of the Charlotte belt.

The near-surface earth materials of the Piedmont consist of a three-stage system that, from top to bottom, contains (1) a regolith zone, (2) a transition zone, and (3) underlying fractured crystalline bedrock. The uppermost layer is the regolith, which consists of an unconsolidated or semiconsolidated mixture of clay and fragmental material ranging in grain size from silt to boulders. The regolith is primarily composed of saprolite, alluvium, and soil (Daniel and Sharpless, 1983). Saprolite, the clay-rich, residual granular material derived from in-place weathering of bedrock, is the dominant deposit in this unconsolidated zone. Saprolite deposits contain principal openings between grains and differ significantly in texture and chemical composition from the parent rock, which is unweathered, crystalline rock with principal openings along fractures. Some textural features of the parent bedrock are retained within the saprolite. Remnant quartz veins, dikes, and shear zones are common in outcrops. Alluvium is unconsolidated sediment deposited by streams or erosion. Alluvium deposits are restricted to locations of current and former stream channels and river beds. Soil deposits generally are restricted to the uppermost layer of the regolith.
Sediment samples from the borings of wells constructed in the row-crop basins indicate that unconsolidated material particle size increases with depth. Surface soils (0-9 feet) were 3 percent coarse sand, 22 percent fine sand, 33 percent silt, and 42 percent clay. Sediment at a 25 - to 40 -foot depth was 3 percent coarse sand, 45 percent fine sand, 46 percent silt, and 6 percent clay. The dominant material is clay near the surface but grades into silt and fine sand at depth.

The transition zone, consisting of saprolite and partially weathered bedrock, is the zone separating unconsolidated material from unweathered bedrock. Particle sizes in this zone range from those characteristic of clay to large boulders of unweathered bedrock. The thickness of the transition zone depends on the texture and composition of the parent rock. Transitional zones are well defined in foliated metamorphic parent rock but are poorly defined in massive igneous rocks.

The uppermost part of the Piedmont crystalline bedrock contains numerous closely spaced fractures that relate to local and regional tectonic history. Few fractures occur in the Piedmont bedrock at depths greater than 400 feet (LeGrand, 1967).

\section{Soils}

Most Piedmont soils have formed largely from saprolite derived from the underlying bedrock. Some soils have developed on stream-valley alluvium. Soils are a product of their local and regional environment. Geology, geomorphology, and climate, in addition to topography, moisture, and vegetation, influence soil characteristics.

Daniels and others (1984) classified four major soil systems within the Piedmont based on the major kinds of bedrock: (1) the felsic crystalline terrains composed largely of granite, gneiss, mica gneiss, and schist, (2) the Carolina slate belt of bedded argillites, felsic volcanic rocks, and mafic volcanic rocks, (3) the Triassic basins of mudstones, sandstones, shales, and conglomerates, and (4) the mixed mafic and felsic rocks: a complex area of granites, diorites, gabbros, and other rocks.

The soils in the study basins are derived from acid crystalline parent rock (U.S. Department of Agriculture, 1977). Most deeper soil horizons are clayey, but some soils that originated from coarser grained rocks have clay-loam or loamy-sand deeper horizons. Sandy-loam soils are evident in the forested basin. The 
Table 2. Approximate percentage of major land uses in the North Carolina Piedmont, the Haw River basin, and the mixed land-use Candy Creek study basin

\begin{tabular}{lccc}
\hline Land use & $\begin{array}{c}\text { Piedmont } \\
\mathbf{1 9 7 6}\end{array}$ & $\begin{array}{c}\text { Haw River } \\
\text { basin }^{2} \mathbf{1 9 8 3}\end{array}$ & $\begin{array}{c}\text { Mixed land- } \\
\text { use basin } \\
\text { mean 1985-90 }\end{array}$ \\
\hline Cropland and pasture......... & 25 & 26 & 60 \\
Forest land ..................... & 66 & 58 & 28 \\
Urban and residential ........ & 6 & 7 & 39 \\
Reservoirs....................... & 1 & 4 & 3 \\
Other & 2 & 5 & 0 \\
\hline
\end{tabular}

${ }^{1}$ Harned, 1989.

${ }^{2}$ U.S. Department of Agriculture, 1985.

${ }^{3}$ Roads and farmsteads.

${ }^{4}$ Includes wetlands, undefined areas, small bodies of water, and streambanks.

reddish clay soils of the Cecil-Madison Associations are the predominant soil types in the study area (table 1) (U.S. Department of Agriculture, 1977). These soil types are generally well drained and have a sandy clay loam, clay loam, and clay subsoil.

\section{Land Use}

Agricultural land uses are an important component of the Piedmont landscape. An estimate of North Carolina Piedmont land use (Harned, 1989) based on 1976 land-use data (Anderson and others, 1976) indicated that cropland and pasture make up about 25 percent of the Piedmont land area (table 2). A 1983 compilation of land use for the Haw River basin (fig. 1), the 1,628-square-mile basin that includes the study area (U.S. Department of Agriculture, 1985), indicated that about 26 percent of the basin area was in cropland and pasture (table 2). The dominant crop types in the Haw River basin were corn (38 percent of cropland), tobacco (23 percent), grain (18 percent), soy beans (17 percent), and other crops (4 percent). Forest land made up about 66 percent of the North Carolina Piedmont, and urban and residential land uses accounted for 6 percent of the land area (Harned, 1989).

The land uses for the row-crop basins and the forested basin did not vary substantially during the period of study. The row-crop basins were 100 percent cropland, which consisted of tobacco, grain, and grass. The forested basin consisted of oak-maple-poplar forest (about 85 percent) and brush (15 percent) (table 1).

Land use varied in the mixed land-use basin during the period of study. Approximately 60 percent of the 665-acre mixed land-use basin was cropland
Table 3. Percentage, by year, of land use and crop type for the mixed land-use basin, Guilford County, North Carolina

\begin{tabular}{|c|c|c|c|c|c|c|}
\hline \multirow{2}{*}{ Specific type of use } & \multicolumn{6}{|c|}{ Percent } \\
\hline & 1985 & 1986 & 1987 & 1988 & 1989 & 1990 \\
\hline \multicolumn{7}{|c|}{ Land use } \\
\hline Cropland ...................... & 48 & 46 & 46 & 47 & 48 & 47 \\
\hline 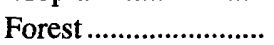 & 31 & 31 & 29 & 27 & 26 & 26 \\
\hline Pasture ......................... & 11 & 11 & 13 & 13 & 13 & 14 \\
\hline Water $^{1}$......................... & 3 & 3 & 3 & 3 & 3 & 3 \\
\hline Other $^{2}$ & 7 & 9 & 9 & 10 & 10 & 10 \\
\hline \multicolumn{7}{|c|}{ Crop type } \\
\hline Tobacco.......................... & 39 & 35 & 24 & 36 & 32 & 43 \\
\hline Grain and grass........ & 42 & 27 & 29 & 24 & 33 & 41 \\
\hline Soybeans...................... & 7 & 12 & 26 & 12 & 5 & 3 \\
\hline Other crops .............. & 6 & 7 & 9 & 4 & 5 & 3 \\
\hline 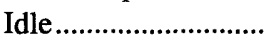 & 6 & 19 & 12 & 24 & 25 & 10 \\
\hline
\end{tabular}

Thirteen farm ponds.

${ }^{2}$ Roads and residential.

and pasture (table 2), reflecting a higher proportion of agricultural land use than in general in the Piedmont. The relative changes in land use and cropland use for the mixed land-use basin from 1985 to 1990 are presented in table 3. Pasture and residential land uses in the basin increased slightly from 1985 to 1990 , and forest land area declined. Total cropland remained about 47 percent of the total land area during the study period. Notably, there was very little corn grown in the basin. The predominant crops were tobacco and small grains.

The mixed land-use basin contained 13 small farm ponds. These ponds are generally used for irrigation, water for cattle, or esthetic or recreational purposes. Assuming this density to be typical for the North Carolina Piedmont, the Piedmont contains approximately 200,000 small farm ponds. These ponds probably have a significant effect on downstream water quality.

\section{Land-Management Practices}

The amount of nonpoint-source contamination produced on agricultural land is partly a function of agricultural land-management practices. Soil erosion and nonpoint-source contamination can be reduced with CLM practices (U.S. Environmental Protection Agency, 1985; Harper, 1987). CLM practices are defined as agricultural operations directed toward reducing nonpoint-source contamination by sediment, nutrients, pesticides, and bacteria (North Carolina Department of Environment, Health, and Natural 
Resources, 1989). These practices include the principal resource management systems recommended for the Haw River basin (U.S. Department of Agriculture, 1985): conservation cropping systems, strip cropping, conservation tillage, contour plowing, field borders, grassed waterways, and terraces or diversions. CLM practices are contrasted with what are referred to in this report as SLM practices. These typically include continuous cropping, straight-row plowing without regard to land topography and slope, and poorly maintained waterways. The paired row-crop basins in this study served as the primary comparison of SLM and CLM practices.

The mixed land-use basin included areas farmed by using SLM and CLM practices. During the period of study, an active program to convert from SLM practices to CLM practices was underway. In 1988, farming practices on 61 acres ( 9.2 percent) of the 665 -acre basin were converted to CLM practices (John W. Andrews, Guilford County Soil and Water Conservation District, oral commun., 1991), and farming practices on an additional 60 acres ( 9.0 percent) were converted to meet land-management requirements of the 1985 Farm Bill (Scaling, 1988). Those requirements, however, were not as comprehensive as the full CLM practices designed to maximize soil conservation. Overall, less than one-third of the cropland in the mixed land-use basin was farmed by using conservation practices in 1988 .

\section{Precipitation}

Precipitation differences between basins complicate the determination of basin differences in streamflow and water quality. Mean seasonal precipitation at the two precipitation stations in the study area, along with mean seasonal streamflow in inches per unit area at the four basins, is shown in figure 2. The difference in precipitation between the two stations measured during the nongrowing season (October-April) was statistically significant (Wilcoxon signed rank test on monthly precipitation; $p=0.03$ ). The mean seasonal precipitation measured at the CLM basin was about 10 percent lower than that measured at the SLM basin for the nongrowing season (fig. 2). This indicates that part of the difference between concentrations of sediment, nutrients, and pesticides in water in the two row-crop basins could be due to different amounts of precipitation that fell on the two basins during the nongrowing season. Precipi-

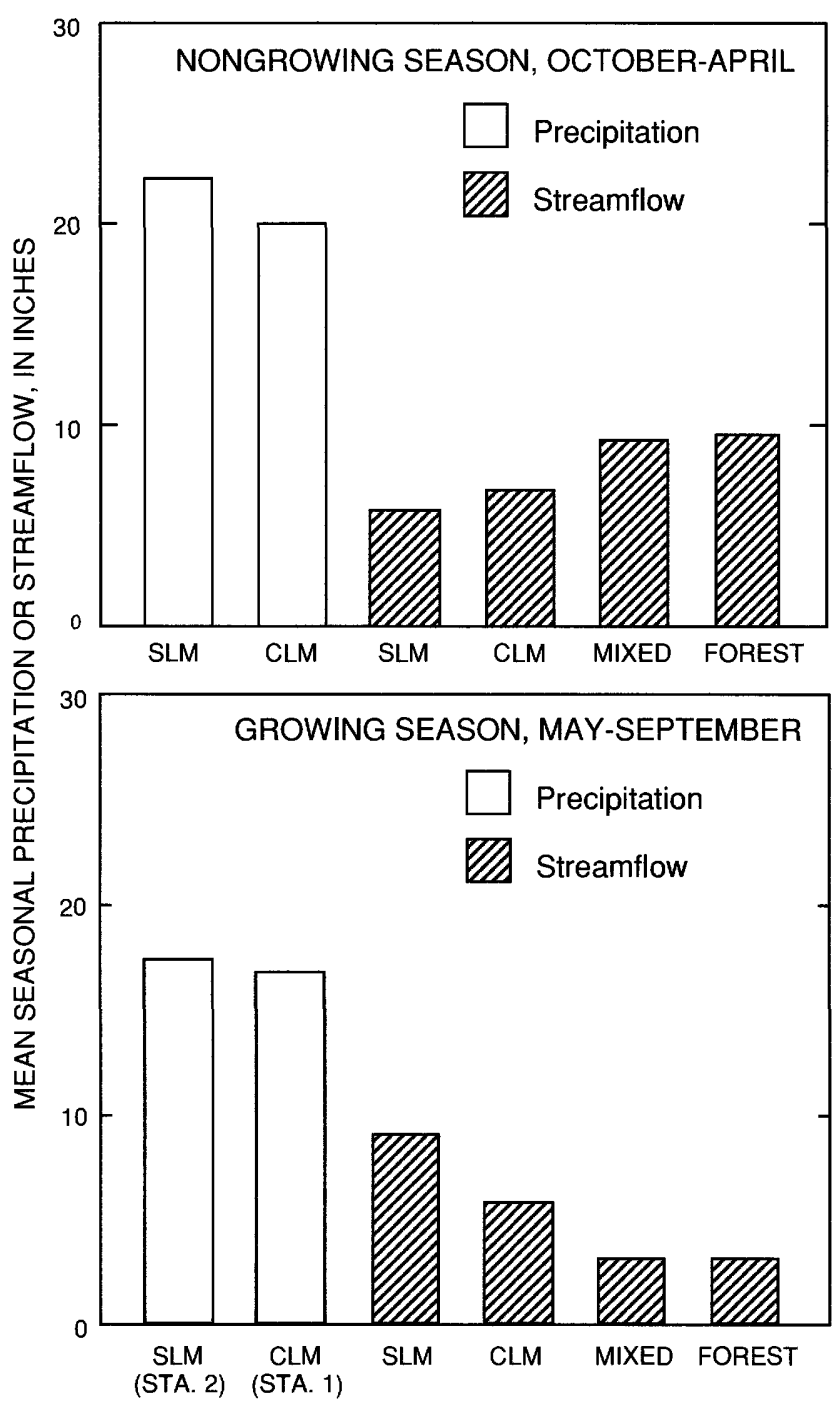

Figure 2. Mean seasonal precipitation at the two precipitation stations and mean seasonal streamflow during nongrowing and growing seasons at the four study basins, 1985-90, Guilford County, North Carolina. SLM, standard land-management practices basin; CLM, conservation landmanagement practices basin; MIXED, mixed land-use basin, FOREST, forested basin; (STA. 2), precipitation station and number.

tation measured during the growing seasons near the CLM basin (station 1) was also slightly less (approximately 4 percent) than that measured at the SLM basin (station 2; fig. 2). However, this difference in precipitation was not statistically significant.

\section{Streamflow}

Discharge at the four basins for the study period differed in part because of land-management practices and land use. Flow in the stream draining the mixed 
Table 4. Streamflow characteristics at the four study basins in Guilford County, North Carolina, 1985-90

[USGS, U.S. Geological Survey; $\mathrm{ft}^{3} / \mathrm{s}$, cubic foot per second; in., inch]

\begin{tabular}{|c|c|c|c|c|c|c|c|}
\hline USGS station & $\begin{array}{c}\text { Mean annual } \\
\text { discharge } \\
\left(f^{3} / \mathbf{s}\right)\end{array}$ & $\begin{array}{l}\text { Mean annual } \\
\text { discharge (in. p } \\
\text { er unit area) }\end{array}$ & $\begin{array}{l}\text { Minimum daliy } \\
\text { discharge } \\
\left(\mathrm{ft}^{3} / \mathbf{s}\right)\end{array}$ & \multicolumn{3}{|c|}{$\begin{array}{l}\text { Discharge at indicated } \\
\text { percentile }\left(\mathrm{ft}^{3} / \mathrm{s}\right)\end{array}$} & $\begin{array}{c}\text { Minimum daily } \\
\text { discharge } \\
\left(f^{3} / s\right)\end{array}$ \\
\hline $\begin{array}{l}\text { Standard land-management practices } \\
\text { basin-Smith Branch upper tributary. }\end{array}$ & 0.01 & 14.81 & 0 & 0 & 0 & 0.01 & 0.7 \\
\hline $\begin{array}{l}\text { Conservation land-management practices } \\
\text { basin-Smith Branch lower tributary. }\end{array}$ & .01 & 12.51 & 0 & 0 & 0 & .01 & 1.8 \\
\hline
\end{tabular}

land-use basin, which had the greatest drainage area, was continuous, and the maximum daily flow at the gaging station was approximately 10 times that of the stream draining the forested basin and 50 times those of streams draining the two row-crop basins. The flow pattern at the mixed land-use basin and at the forested basin indicates a particularly dry period from April 1987 through February 1989. The streamflow record for the mixed land-use site indicates a comparatively wet period from March 1989 through October 1990. The pattern of dry and wet periods was not as apparent at the row-crop basins, in part, because the basins were irrigated during dry periods. Although a complete record of irrigation was not collected at the two rowcrop basins, the farmer's log indicates that both basins were irrigated with equivalent amounts of water.

A summary of daily value streamflow statistics for the four stations in the study basins (table 4) indicates that the row-crop basins have ephemeral drainages that flow only during and briefly after rain storms and following some periods of irrigation. Streams draining the mixed land-use basin and the forested basin flowed continuously during the period of study. Low flows at these two sites are sustained by groundwater discharge.

\section{Ground-Water Levels}

Potentiometric-surface maps for the two rowcrop basins (fig. 3), one for a period of low water levels (August 15, 1986) and one for a period of high water levels (March 31, 1986), show that water-level contours generally follow land-surface altitude contours (fig. 4) in the western two-thirds of both basins, and ground water generally flows westward. However, regional ground-water flow patterns and water-level data indicate the presence of a ground-water flow divide through the basins. Ground water east of this divide flows to the east. Seasonal differences in the water-level contours do not appreciably alter the apparent ground-water flow patterns in the two rowcrop basins.

The unsaturated zone is important with respect to the recharge and movement of nutrients and pesticides to the ground-water system in the row-crop basins. The depth to the water table at well 101, in particular, is only a few feet, whereas the depth to water at the eastern margins of both row-crop basins can be more than 25 feet (well 202) (fig. 5). The areas with thick unsaturated zones have a greater capacity to intercept and store nutrients and pesticides than the areas with thinner zones. The thick unsaturated zones of the eastern margins of the basins, therefore, could have stored nutrients and pesticides applied prior to the 1985-90 study and served as sources to the ground-water system.

\section{METHODS OF STUDY}

The methods of study included surface-water and ground-water data collection, precipitation measurement and sampling, soil sampling, and maintenance of a record of farming activities. Data analysis involved statistical summaries and comparisons of the data collected.

\section{Data Collection}

Data collected during this study included stage and discharge data at the four gaging stations; groundwater level data; precipitation data; and chemicalquality data at the surface-water stations, selected ground-water sites, and the precipitation stations (Hill, 1989). Data were collected from 4 surface-water recorders for gage height; 4 automatic water samplers 

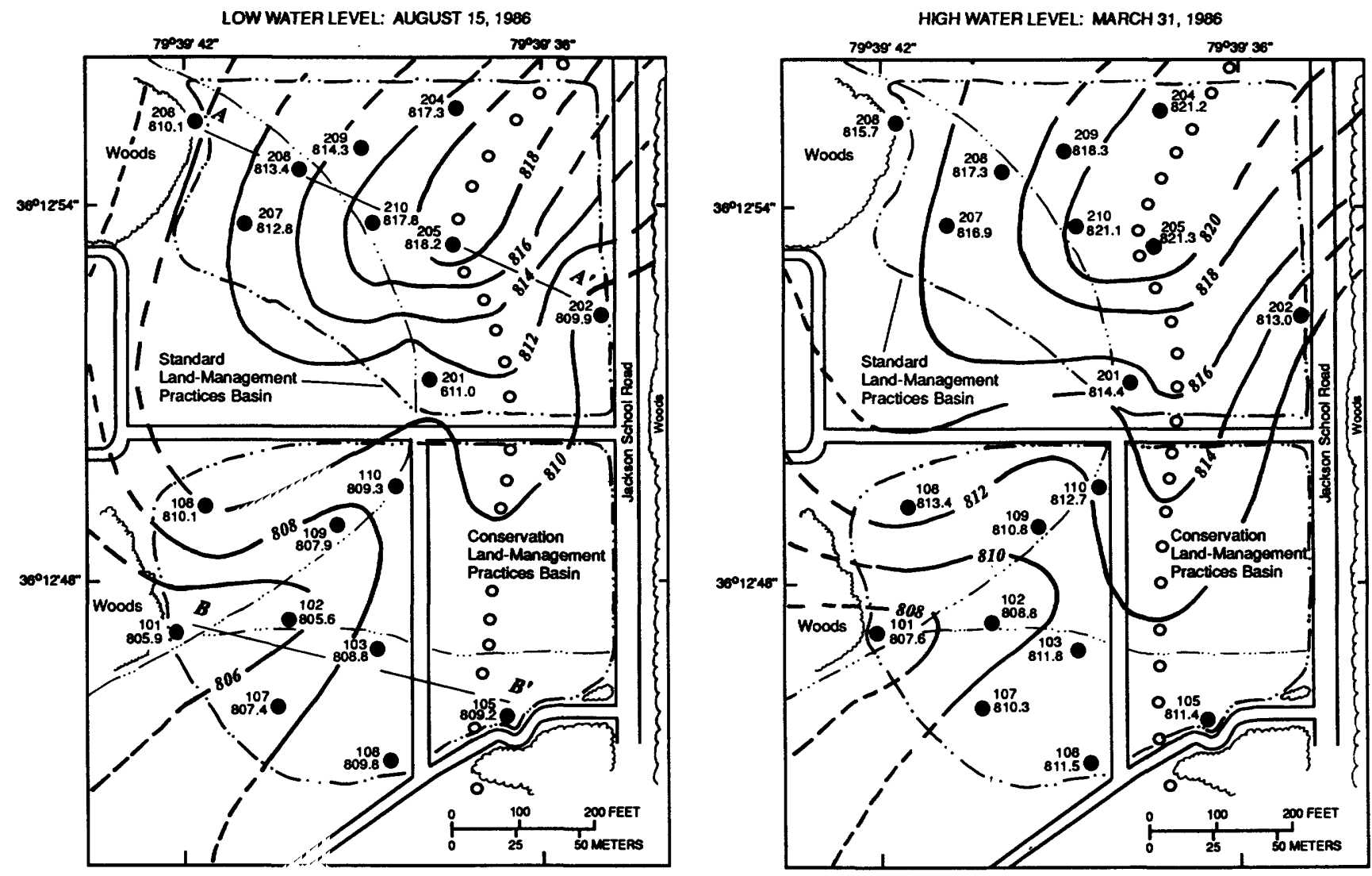

EXPLANATION
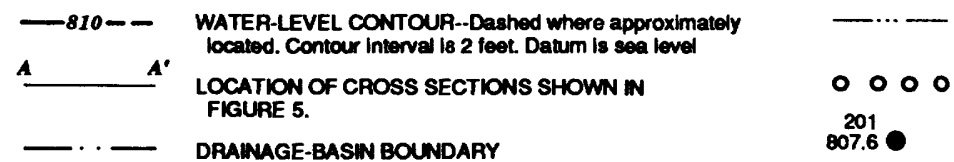

WTERMITENT STREAM

○ 0 O 0 ground-water divide

201
807.6

OBSERVATION WELL AND WELL NUMBEA WTTH MEASURED WATER-LEVEL ALTITUDE, W FEET ABOVE SEA LEVEL

Figure 3. Potentiometric surface on August 15, 1986, and March 31,1986 , at the two row-crop basins, Guilford County, North Carolina.

for collection of surface-water quality samples during storm events; 2 recording rain gages; 2 recording water-level recorders at wells; 18 ground-water monitoring wells for periodic ground-water levels and collection of ground-water quality samples; and 39 lysimeters for sampling soil water in the unsaturated zone. A summary of the categories and types of data collected, as well as the sampling frequency, is presented in table 5. Ground-water levels and precipitation totals were monitored only at the two row-crop basins; surface water was monitored at all four basins. Soil samples were collected only at the row-crop basins.

Precipitation was monitored at two stations, one about 400 feet east of the stream gage for the CLM basin (station 1) and the other at the northeastern border of the SLM basin (station 2) (fig. 4). A bulk precipitation sampler, adjacent to precipitation station 1 east of the CLM basin, was used to collect precipitation for analysis of specific conductance, $\mathrm{pH}$, and concentrations of total nitrogen, total organic nitrogen, total ammonia nitrogen, total ammonia and organic nitrogen, total nitrite plus nitrate, total phosphorus, and total orthophosphorus. Precipitation samples were analyzed by the USGS National Water-Quality Laboratory using methods described by Fishman and Friedman (1985).

Stream stage was monitored continuously in all four basins, and discharge measurements were made periodically to develop stage-discharge relations. At the row-crop basins, streamflow occurred only during irrigation of the basins or during and immediately following precipitation in the basins. 


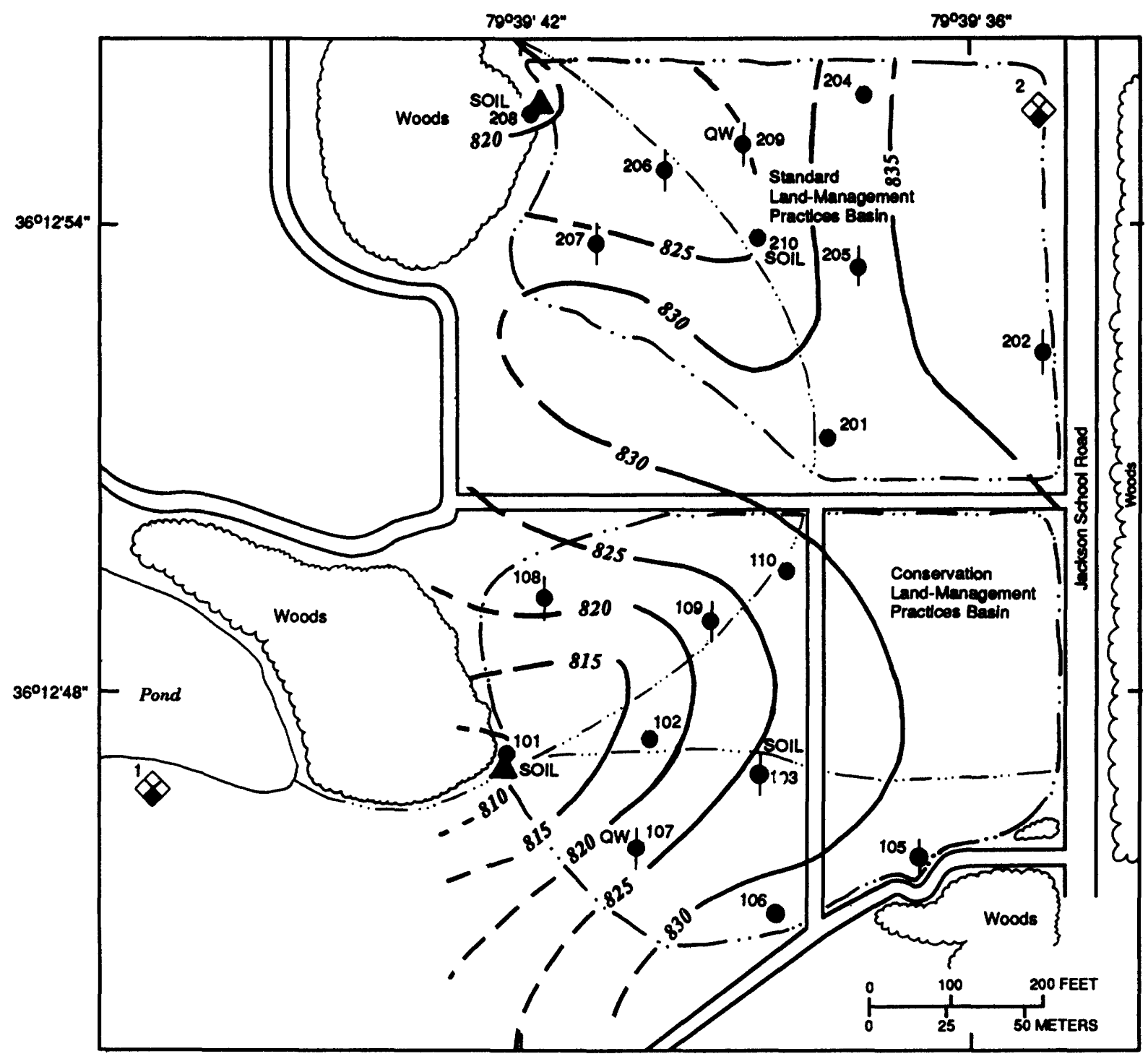

\section{EXPLANATION}
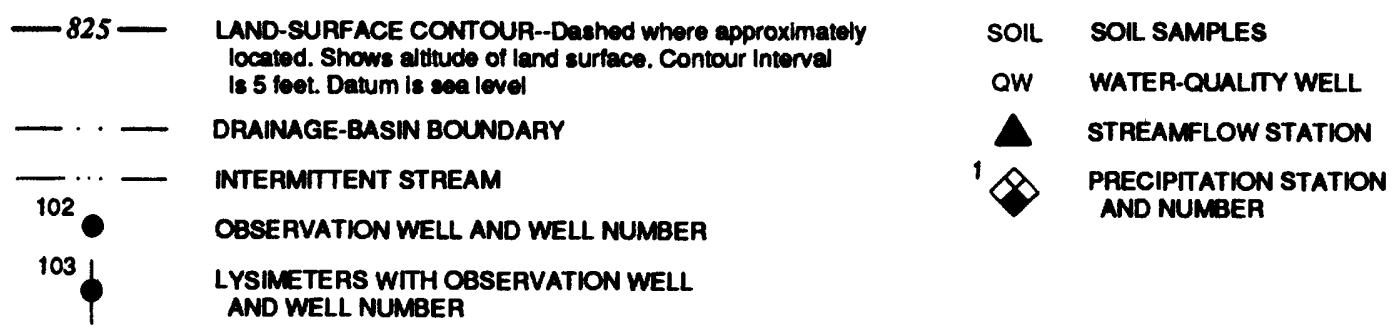

Figure 4. Land-surface altitudes and locations of wells, stream gages, precipitation stations, and intermittent streams in the row-crop basins, Guilford County, North Carolina.

Surface-water quality samples collected from the four basins were analyzed for specific conductance, $\mathrm{pH}$, and concentrations of suspended sediment, selected nutrients, and selected pesticides. Surfacewater and sediment-collection methods are described by Hill (1991). Specific conductance and $\mathrm{pH}$ were evaluated on site, and suspended-sediment concentrations were analyzed by the USGS sediment laboratory in Raleigh, N.C. The nutrients examined included total nitrogen, total organic nitrogen, total ammonia 
STANDARD LAND-MANAGEMENT PRACTICES BASIN

$\boldsymbol{A}$

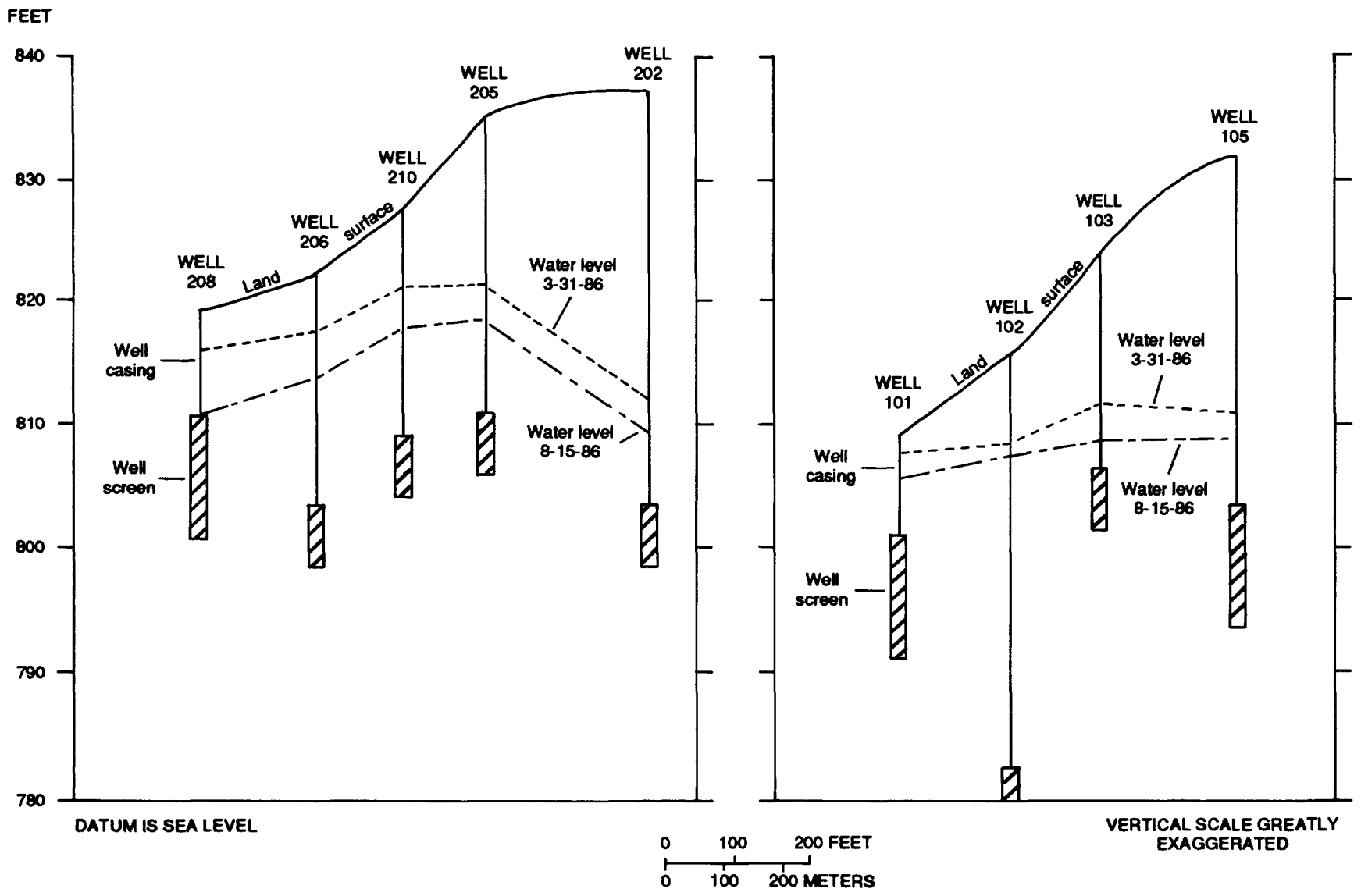

Figure 5. Hydrogeologic sections $A-A^{\prime}$ at the standard land-management practices basin and $B-B^{\prime}$ at the conservation landmanagement practices basin, Guilford County, North Carolina (lines of sections shown in fig. 3).

Table 5. Summary of data-collection frequencies at the four study basins, 1985-90, Guilford County, North Carolina [Basin locations shown in figure 1; SLM, standard land-management practices; CLM, conservation land-management practices]

\begin{tabular}{|c|c|c|}
\hline Data category & Data type & Sampling or measurement frequencies \\
\hline \multirow[t]{2}{*}{ Surface water ............... } & Stream stage & $\begin{array}{l}\text { 5-minute intervals at the SLM and CLM basins; } 15 \text {-minute intervals at } \\
\text { the mixed land-use and forested basins. }\end{array}$ \\
\hline & Discharge & Periodic (to establish stage-discharge relation). \\
\hline \multirow[t]{2}{*}{ Ground water ............... } & Ground-water levels & $\begin{array}{l}\text { Hourly from wells } 101 \text { and } 208 \text {; monthly at } 16 \text { wells in the SLM and } \\
\text { CLM basins. }\end{array}$ \\
\hline & Nutrients & Quarterly from wells 107 and 209. \\
\hline Soil water ........................ & Nutrients & $\begin{array}{l}\text { Weekly in the spring of each year from } 39 \text { lysimeters in the SLM and } \\
\text { CLM basins. }\end{array}$ \\
\hline \multirow[t]{2}{*}{ Precipitation................. } & Accumulation & 5-minute intervals. \\
\hline & Nutrients & 5 times per year at precipitation station 1 only. \\
\hline 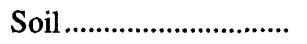 & Pesticides & Biannually at the SLM and CLM basins. \\
\hline Farming activities ....... & $\begin{array}{l}\text { Agricultural practices and chemical } \\
\text { applications. }\end{array}$ & Weekly at the SLM and CLM basins. \\
\hline
\end{tabular}


Table 6. Summary of well-construction characteristics

[USGS, U.S. Geological Survey; LSD, land-surface datum; WLM, water-level measurement; QWS, water-quality sampling]

\begin{tabular}{|c|c|c|c|c|c|c|c|c|}
\hline \multirow{2}{*}{$\begin{array}{l}\text { Well number } \\
\text { (fig. 4) }\end{array}$} & \multirow[b]{2}{*}{ USGS slte number } & \multirow{2}{*}{$\begin{array}{l}\text { Altitude of LSD } \\
\text { (feet above } \\
\text { sea level) }\end{array}$} & \multirow{2}{*}{$\begin{array}{l}\text { Depth } \\
\text { (feet) }\end{array}$} & \multicolumn{2}{|c|}{ Casing } & \multicolumn{2}{|c|}{ Screen } & \multirow[b]{2}{*}{ Well use } \\
\hline & & & & $\begin{array}{l}\text { Diameter } \\
\text { (Inches) }\end{array}$ & $\begin{array}{l}\text { Depth } \\
\text { (feet) }\end{array}$ & $\begin{array}{l}\text { From } \\
\text { (feet) }\end{array}$ & $\begin{array}{c}\text { To } \\
\text { (feet) }\end{array}$ & \\
\hline \multicolumn{9}{|c|}{ Conservation land-management practices basin } \\
\hline${ }^{1} 101$ & 361248079394201 & 809.5 & 18.5 & 4 & 8.5 & 8.5 & 18.5 & WLM \\
\hline 102 & 361248079394101 & 816.1 & 35.5 & 2 & 33.5 & 33.5 & 35.5 & WLM \\
\hline 103 & 361248079393901 & 824.7 & 23.5 & 2 & 18.5 & 18.5 & 23.5 & WLM \\
\hline 107 & 361247079394001 & 822.6 & 28.5 & 2 & 23.5 & 23.5 & 28.5 & QWS, WLM \\
\hline 108 & 361249079394201 & 821.9 & 23.5 & 2 & 18.5 & 18.5 & 23.5 & WLM \\
\hline 109 & 361249079394001 & 821.9 & 18.5 & 2 & 13.5 & 13.5 & 18.5 & WLM \\
\hline 110 & 361250079393901 & 829.8 & 28.5 & 2 & 18.5 & 18.5 & 28.5 & WLM \\
\hline 205 & 361254079393801 & 835.1 & 28.5 & 2 & 23.5 & 23.5 & 28.5 & WLM \\
\hline 206 & 361254079394001 & 822.1 & 23.5 & 2 & 18.5 & 18.5 & 23.5 & WLM \\
\hline 207 & 361253079394101 & 828.9 & 33.5 & 2 & 28.5 & 28.5 & 33.5 & WLM \\
\hline${ }^{1} 208$ & 361255079394201 & 819.3 & 18.5 & 4 & 8.5 & 8.5 & 18.5 & WLM \\
\hline 209 & 361255079394001 & 824.6 & 23.5 & 2 & 18.5 & 18.5 & 23.5 & QWS, WLM \\
\hline 210 & 361253079393901 & 827.9 & 23.5 & 2 & 18.5 & 18.5 & 23.5 & WLM \\
\hline
\end{tabular}

${ }^{1}$ Well equipped with analog-digital recorder.

nitrogen, total ammonia and organic nitrogen, total nitrite plus nitrate, total phosphorus, total orthophosphorus, and total potassium.

The pesticides analyzed were acephate, ethoprop, metalaxyl, diphenamid, isopropalin, fenamiphos, flumetralin, and napropamide. These pesticides were selected for monitoring because they represented a variety of common chemicals used in tobacco cultivation during the study. Water and soil samples collected in the study basins during 1985-88 were analyzed for these compounds by the Research Triangle Institute laboratory, Research Triangle Park, N.C., using a gas chromatograph with capillary column and a flame ionization detector. Water and soil samples collected during 1989-90 were analyzed for these pesticides at the USGS National Water-Quality Laboratory using a gas chromatograph with a capillary column and a mass spectrometer operated in the electron impact mode with single ion monitoring.

Ground-water level data, ground-water samples, and unsaturated zone water samples were collected from the two row-crop basins. Locations of the observation wells used for water-level measurements and collection of ground-water samples and locations of the lysimeters used to collect soil-water samples are shown in figure 4. A summary of well-construction characteristics for the 18 observation wells in the two row-crop basins is presented in table 6 .

Records of farming activities, including chemical and fertilizer applications and other information regarding cultivation of the tobacco and wheat crops in the two row-crop basins, were maintained by Guilford County Soil and Water Conservation District personnel. No records of farming activities were maintained for the mixed land-use or the forested basins. A summary of the logs kept on farming activities is presented in appendix 1 , and a log of chemical and fertilizer applications is presented in appendix $2 \mathrm{~A}-\mathrm{F}$.

\section{Data Analysis}

Analysis of the data collected during this study involved statistically summarizing the data, comparing concentrations and yields of sediment, nutrients, and pesticides among basins, and using regression analysis to estimate sediment and nutrient yields. Comparisons among basins with different land-management practices were based on nonparametric statistical tests and are summarized in this report by bar charts and box plots. 
Basin comparisons were based on the nonparametric Kruskall-Wallis analysis of variance to establish whether a difference existed among multiple distributions (Helsel and Hirsch, 1992). When a significant difference was identified, a Wilcoxon ranked sum test was used to determine which distributions were different. In the Wilcoxon test, data values are ranked, and the statistical comparisons are made using the sums of the ranks. Only the results for those comparisons that indicated significant differences among multiple distributions using the Kruskall-Wallis analysis were included in the appendixes giving Wilcoxon significance levels. The level of significance, or alpha level, used in hypothesis testing in this report was 0.05 . If the test probability level was less than or equal to the alpha level of 0.05 , then the hypothesis that there is no difference between distributions was rejected. To simplify the statistical terminology in this report, comparisons between concentration distributions based on the Wilcoxon test of sums of ranked values are referred to as comparisons between basin constituent concentrations.

The minimum variance unbiased estimator technique (MVUE), described by Cohn and others (1989) and by Gilroy and others (1990), was used to estimate sediment and nutrient yields. This approach uses regression analysis to model constituent-discharge relations. The MVUE technique corrects for downward bias, which occurs in yield estimates that are obtained using log-log constituent-discharge relations.

\section{EFFECTS OF LAND USE AND LAND- MANAGEMENT PRACTICES ON STREAMFLOW}

Land-management practices devised to control soil erosion also affect hydrology. For example, grassed swales designed to trap sediment in the roots and stems of plants also reduce the velocity of surfacewater flow, resulting in further sediment deposition. Contour plowing, as opposed to plowing without regard to surface slopes, reduces surface-water flow velocities, increases infiltration of surface water into the soil, and reduces soil erosion. The hydrologic effects of differing land-management practices are observable in a comparison of surface-water data among the four study basins.

A basin comparison for annual streamflow in inches per unit area removes the effect of basin size on the streamflow output and indicates a difference between the row-crop basins that probably results from land-management practices. The SLM practices basin had higher mean annual discharge (14.81 inches) per unit area than the other basins (table 4). The difference in streamflow between the SLM basin and the CLM practices basin was statistically significant (Wilcoxon signed rank test on monthly streamflow, $p=0.04)$. Discharge per unit area was similar for the CLM basin (12.51 inches), the mixed land-use basin (12.36 inches), and the forested basin (12.64 inches).

Mean seasonal streamflow from the SLM basin in the nongrowing season (October-April) was about 9 percent less $(p=0.02)$ than that observed for the CLM basin during the study, even though the SLM basin received 10 percent more precipitation than the CLM basin. The SLM basin had about 39 percent less streamflow, and the CLM basin had about 30 percent less streamflow than was observed in either the mixed land-use basin or the forested basin. These differences are statistically significant (Wilcoxon signed-rank test on monthly streamflow; probability in all cases $<0.01$ ). The difference in streamflow between the mixed land-use and the forested basins was not significant.

During the nongrowing season, the entire SLM basin was disked, and about half of the CLM basin was disked. Disking produces a rough soil surface that enhances infiltration of precipitation into the ground and decreases surface-water flow. The net result was lower streamflow for the SLM basin relative to that observed for the CLM basin and lower streamflow for both row-crop basins relative to the streamflow observed for the mixed land-use and the forested basins (fig. 2).

In the growing season (May-September), streamflow was greatest from the SLM basin, followed by the CLM basin, and the forested and mixed land-use basins. Mean seasonal streamflow for the SLM basin was 290 percent that of the mixed landuse and forested basins, and 155 percent that of the CLM basin. The difference between streamflow for the row-crop basins and the mixed land-use basin was statistically significant (Wilcoxon signed-rank test on monthly streamflow; SLM basin, $p<0.01$; CLM basin, $p=0.01$ ). The difference between streamflow for the SLM basin and the forested basin was also significant at a probability of less than 0.01 . However, the difference between streamflow for the CLM basin and streamflow for the forested basin was not significant at the 0.05 probability level. Comparisons between the 
growing season monthly streamflows for the mixed land-use basin and the forested basin indicated no significant difference, and the mean values for the period of record were the same (fig. 2). This may have resulted, in part, because of effects of the ponds in the mixed land-use basin and also because the mixed landuse basin was approximately one-quarter forested.

The comparisons demonstrate a distinct, and statistically significant, effect of reduction of streamflow during the growing season by CLM practices. This reduction is apparent despite the higher slope of the CLM basin (4.6 percent) than the slope of the SLM basin ( 2.3 percent), a condition that would favor higher surface-water flow from the CLM basin.

\section{EFFECTS OF LAND USE AND LAND- MANAGEMENT PRACTICES ON WATER QUALITY}

Comparisons of physical water-quality characteristics, sediment concentrations and yields, nutrient concentrations and yields, and selected pesticide concentrations among the study basins are described in this section to assess the effects of land use and landmanagement practices on water quality. Information on the quality of precipitation, background water quality in the Piedmont of North Carolina, and selected water-quality criteria also are provided for a frame of reference.

\section{Physical Properties}

Physical properties, including $\mathrm{pH}$, specific conductance, and dissolved-solids concentration, were measured in surface water at the four study basins. In addition, measurements for $\mathrm{pH}$ and specific conductance were made in ground-water samples from well 107 in the CLM basin and well 209 in the SLM basin and in precipitation samples from station 1 near the CLM basin. Summary statistics for physical properties are given for surface water and precipitation in table 7 , and for ground water in table 8.

\section{pH}

The $\mathrm{pH}$ of water is fundamental to the nature of chemical reactions that occur in water. In general, aquatic life requires $\mathrm{pH}$ to be within a range of 6.5 to 9 units (U.S. Environmental Protection Agency, 1986).
Low $\mathrm{pH}$ values can increase the solubility of materials toxic to aquatic life and can cause detrimental effects. A lower limit of $6.0 \mathrm{pH}$ units has been established by the North Carolina Environmental Management Commission (1979) as the criterion for waters used for fishing and recreation. A study of background conditions in forested basins in the North Carolina Piedmont reported $\mathrm{pH}$ values ranging from 5.0 to 7.5 (Caldwell, 1992).

Surface water in all four of the study basins had higher $\mathrm{pH}$ values (less acidic) than did precipitation, and $\mathrm{pH}$ values for surface waters from the mixed landuse and forested basins were higher than those of surface waters from the row-crop basins. The $\mathrm{pH}$ values of surface waters generally were higher in the CLM basin than in the SLM basin. The $\mathrm{pH}$ values of surface-water samples from the four basins and of precipitation samples from the station near the CLM basin are summarized in figure $6 \mathrm{~A}$ and table 7 . The $\mathrm{pH}$ values for surface waters in all four basins were significantly different from the $\mathrm{pH}$ of precipitation. The $\mathrm{pH}$ values for surface water in the CLM basin were significantly higher than $\mathrm{pH}$ for surface water in the SLM basin (app. 3). The $\mathrm{pH}$ values were significantly lower for surface water in the row-crop basins than for surface water in the forested and mixed land-use basins. The $\mathrm{pH}$ values for the forested and mixed land-use basins were not significantly different. Differences in $\mathrm{pH}$ might reflect a general buffering effect produced by different lengths of flow paths as a result of land use, land management, and basin size. The SLM basin, with the shortest flow paths, had the most acidic $\mathrm{pH}$ values; the CLM basin, with longer flow paths, had less acidic $\mathrm{pH}$ values; and the mixed land-use and forested basins, with the longest flow paths, had the least acidic $\mathrm{pH}$ values. In addition, nitrification of ammonia from fertilizer added to agricultural areas has an acidifying effect on soils (Brady, 1974).

The $\mathrm{pH}$ values for ground water in the SLM basin were higher than those observed for surface water and ground water in the CLM basin. Values of $\mathrm{pH}$ were determined from ground-water samples collected from well 209 in the SLM basin and from samples collected from well 107 in the CLM basin (fig. 4). Box plots of the $\mathrm{pH}$ values for ground water are shown in figure $6 \mathrm{~A}$. The $\mathrm{pH}$ values for ground water in the SLM basin varied over a larger range and were higher than $\mathrm{pH}$ values for surface water from the basin, probably because of buffering of precipitation in the soil zone. The $\mathrm{pH}$ values for ground water in the CLM 
Table 7. Summary statistics for physical water-quality properties of surface water in the four study basins and of precipitation at station 1, 1985-90, Guilford County, North Carolina

[ft ${ }^{3} / \mathrm{s}$, cubic foot per second; $\mu \mathrm{S} / \mathrm{cm}$, microsiemens per centimeter at $25^{\circ} \mathrm{C}$; - , not calculated; $\mathrm{mg} / \mathrm{L}$, milligram per liter]

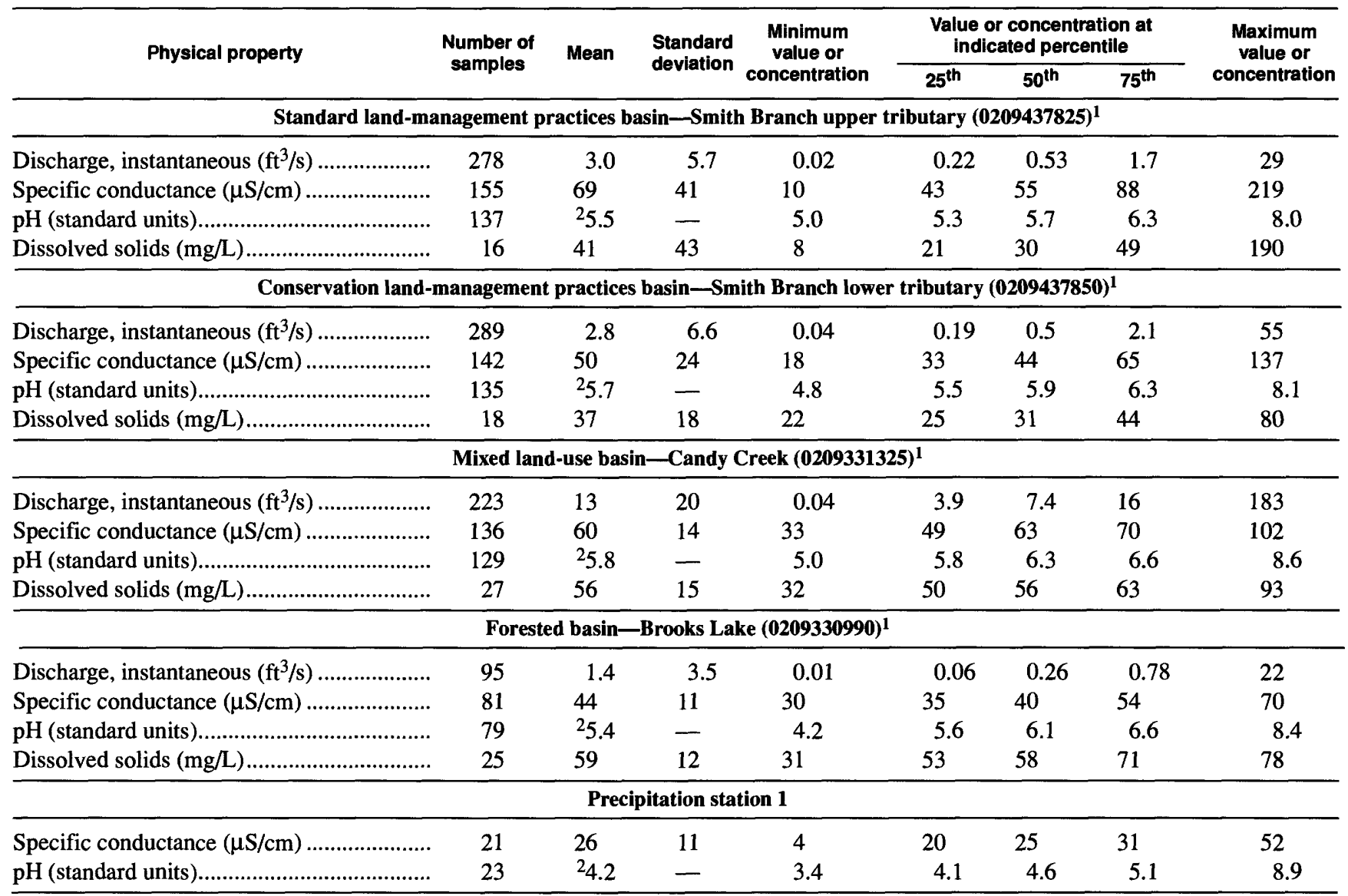

${ }^{1}$ U.S. Geological Survey downstream order identification number.

${ }^{2}$ Mean calculated by using hydrogen ion concentrations.

Table 8. Summary statistics for specific conductance and pH in samples collected from wells 209 and 107 in the row-crop basins, 1985-90, Guilford County, North Carolina

$\left[\mu \mathrm{S} / \mathrm{cm}\right.$, microsiemens per centimeter at $25^{\circ} \mathrm{C} ;-$, not calculated]

\begin{tabular}{|c|c|c|c|c|c|c|c|c|}
\hline \multirow{2}{*}{ Physical property } & \multirow{2}{*}{$\begin{array}{l}\text { Number of } \\
\text { samples }\end{array}$} & \multirow{2}{*}{ Mean } & \multirow{2}{*}{$\begin{array}{l}\text { Standard } \\
\text { deviation }\end{array}$} & \multirow{2}{*}{$\begin{array}{c}\text { Minimum value } \\
\text { or } \\
\text { concentration }\end{array}$} & \multicolumn{3}{|c|}{$\begin{array}{l}\text { Value or concentration at } \\
\text { Indicated percentile }\end{array}$} & \multirow{2}{*}{$\begin{array}{c}\text { Maximum } \\
\text { value or } \\
\text { concentration }\end{array}$} \\
\hline & & & & & $25^{\text {th }}$ & $50^{\text {th }}$ & $75^{\text {th }}$ & \\
\hline \multicolumn{9}{|c|}{ Well 209-Standard land-management practices basin-Smith Branch upper tributary $(0209437825)^{1}$} \\
\hline 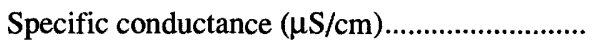 & 57 & 64 & 45 & 22 & 27 & 45 & 85 & 260 \\
\hline 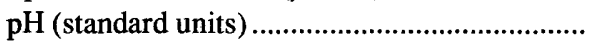 & 57 & 25.7 & - & 4.8 & 5.7 & 6.4 & 7.0 & 10.8 \\
\hline \multicolumn{9}{|c|}{ Well 107-Conservation land-management practices basin-Smith Branch lower tributary $(0209437850)^{1}$} \\
\hline 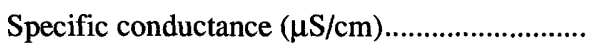 & 56 & 45 & 27 & 16 & 32 & 40 & 48 & 148 \\
\hline pH (standard units) & 55 & 25.4 & - & 4.8 & 5.3 & 5.8 & 6.5 & 8.0 \\
\hline
\end{tabular}

${ }^{1}$ U.S. Geological Survey downstream order identification number.

${ }^{2}$ Mean calculated by using hydrogen ion concentrations. 

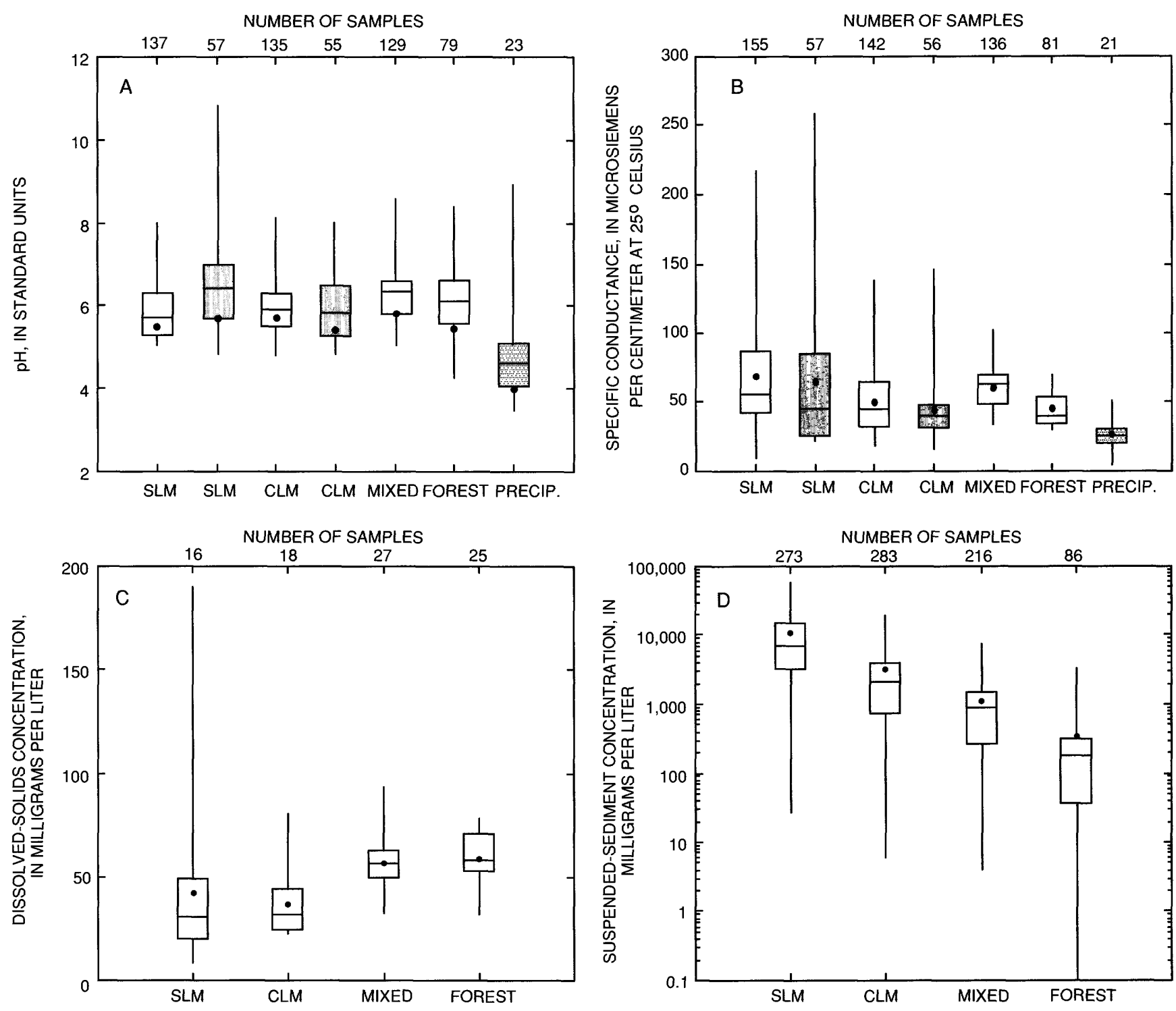

EXPLANATION
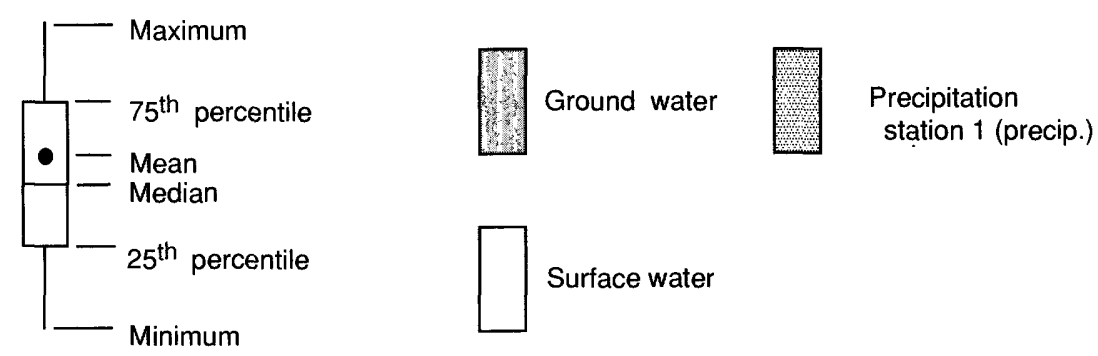

Figure 6. Summary of $\mathrm{A}, \mathrm{pH} ; \mathrm{B}$, specific conductance; $\mathrm{C}$, dissolved-solids concentrations; and $D$, suspendedsediment concentrations in surface and ground water and in SLM, standard land-management practices basin; CLM, conservation land-management practices basin; MIXED, mixed land-use basin, FOREST, forested basin. precipitation, 1985-90, Guilford County, North Carolina. 
basin varied over a larger range but were not significantly different in magnitude from $\mathrm{pH}$ values for surface water from the basin. The $\mathrm{pH}$ values for ground water were significantly higher in the SLM basin than in the CLM basin. The higher $\mathrm{pH}$ probably reflects different fertilization practices. During the study period, less nitrogen fertilizer was applied in the SLM basin than in the CLM basin. Greater ammonia nitrogen from fertilizer can result in increased nitrification and lower $\mathrm{pH}$.

\section{Specific Conductance}

Specific conductance is a measure of the ability of water to conduct an electric current and is a function of the amount of ionic material dissolved in water. In forested basins in the North Carolina Piedmont, specific conductance of surface water generally ranges from 5 to 56 microsiemens per centimeter at $25^{\circ} \mathrm{C}$ during high flows (Caldwell, 1992).

Specific conductance values for surface water generally were higher for the SLM basin than for the CLM basin and the forested basin (app. 3). Specific conductance data for the four basins and for precipitation from the station near the CLM basin are summarized in figure $6 \mathrm{~B}$ and table 7. Surface water in the SLM basin generally had the highest and most variable specific conductance values, and precipitation generally had the lowest and least variable specific conductance values. Specific conductance values for the SLM basin were not significantly different from those for the mixed land-use basin. The specific conductance values for the CLM basin were more similar to those measured in the forested basin than to those measured in the other agricultural sites.

The higher specific conductance values for the SLM basin indicate a greater amount of dissolved material in surface water from that basin than in surface water from the other basins. This could be due to greater mixing of soil materials and water in the higher energy, shorter flow-path microenvironment of the land surface of the SLM basin compared to the lower energy, longer flow-path microenvironment of the CLM basin.

No distinct effects of land-management practices on specific conductance values for ground water were observed. Box plots of specific conductance of ground-water samples collected from wells 107 and 209 are shown in figure 6B. The differences between specific conductance values for ground water and surface water were not statistically significant. Further, the differences between specific conductance values for ground water in the CLM and SLM basins were not significant.

\section{Dissolved Solids}

The amount of dissolved material, or dissolved solids, in water is environmentally important because high dissolved-solids concentrations can limit the suitability of the water for some uses, and dissolved solids play a role in the types of aquatic life that populate the waters. Concentrations of dissolved solids in surface water in the Piedmont have been reported to range from 15 to 61 milligrams per liter $(\mathrm{mg} / \mathrm{L})$ in forested basins (Caldwell, 1992).

Dissolved-solids concentrations in surface water from the row-crop basins were significantly lower than concentrations in surface water from the mixed land-use and forested basins. Dissolved-solids concentrations for surface-water samples collected from the four study basins are summarized in figure $6 \mathrm{C}$ and table 7. The SLM basin had the greatest overall variation in dissolved-solids concentrations, but these concentrations were not significantly different from those for the CLM basin (app. 3). Dissolved-solids concentrations for the mixed land-use basin were not significantly different from the concentrations for the forested basin. The generally higher dissolved-solids concentrations in the mixed land-use and forested basins could be due to longer water residence times in these basins. A longer residence time for water allows more dissolution of inorganic salts, which constitute most of the dissolved solids. Also, low flows at the mixed land-use and forested basins are sustained by ground-water discharge, which typically has higher dissolved-solids concentrations, whereas there is no ground-water contribution to streams in the row-crop basins. The greater supply of organic material, such as leaf litter, in the mixed land-use and forested basins could also contribute to the dissolved organic fraction of dissolved solids in water in those basins.

\section{Suspended Sediment}

Sediment is the solid material transported in streamflow, either in suspension or along the stream bottom. It consists primarily of the fragmental material that originates from weathering of rocks but commonly includes particles of soils and organic debris. Many nutrients, trace metals, and pesticides are readily sorbed and transported by sediment particles. 
Table 9. Summary statistics for suspended sediment in surface water at the four study basins, 1985-90, Guilford County, North Carolina

[mm, millimeter; $\mathrm{mg} / \mathrm{L}$, milligram per liter]

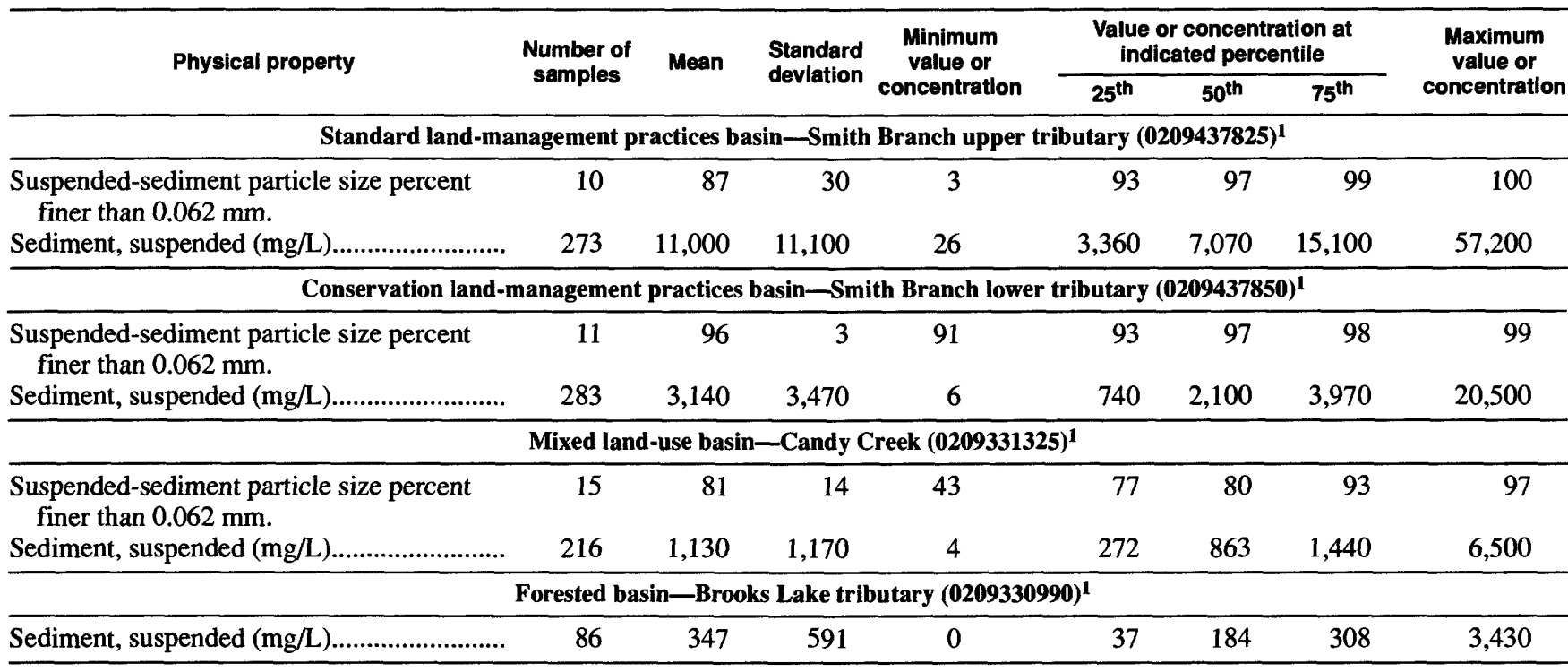

${ }^{1}$ U.S. Geological Survey downstream order identification number.

Only the suspended component of fluvial sediment transport was evaluated in this study. The bedyield component of sediment transport is generally reported to be considerably less than suspendedsediment transport. Gregory and Walling (1973) reported bed-yield values for 15 basins of generally less than 10 percent of total sediment yield.

This report presents data on suspendedsediment concentrations and estimates of suspendedsediment yields from the four study basins. Sediment concentrations are important for assessing instream effects of sediment on biota and stream aesthetics. Sediment yields are important for evaluating erosion and effects of sediment on channel and reservoir filling.

\section{Suspended-Sediment Concentrations}

Suspended-sediment concentrations in streams in 18 North Carolina forested Piedmont basins were reported by Simmons and Heath (1982) and Simmons (1988) to range from 0 to $383 \mathrm{mg} / \mathrm{L}$. In an evaluation of four additional forested sites in the area, Caldwell (1992) reported a sediment concentration range of 0 to $1,120 \mathrm{mg} / \mathrm{L}$. These studies were designed to characterize surface-water quality for undeveloped or natural conditions.

The highest median suspended-sediment concentrations in the four study basins were in the surface water of the SLM basin, which had a median concentration 3.4 times that of the CLM basin, 8.2 times that of the mixed land-use basin, and 38 times that of the forested basin (table 9). Box plots summarizing suspended-sediment concentration data collected in the four study basins are shown in figure 6D. The differences in suspended-sediment concentrations among the four study basins are statistically significant.

The surface water in the mixed land-use basin, which is predominantly agricultural, had a lower median suspended-sediment concentration than water in the row-crop basins. The lower suspended-sediment concentration in this basin could be due to the 13 small farm ponds in the basin, which function as sediment, nutrient, and pesticide traps between farm fields and receiving streams.

The suspended sediment in surface water from the SLM basin included slightly larger particle sizes than did suspended sediment in water from the CLM basin. Results of a selected number of analyses of sediment particle size are summarized in table 9. The total percent of suspended sediment finer than 0.062 millimeter for the two row-crop basins and the mixed landuse basin was evaluated in the analysis. A sediment particle size of 0.062 millimeter ( $\mathrm{phi}=4.0$ ) or finer includes silt and clay in the Wentworth (1922) size class. The larger particle size observed in the SLM basin probably results from the higher energy, higher velocity flows in that basin as compared to flows 
Table 10. Yields of total suspended sediment and nutrients in surface water at the four study basins, 1985-90, Guilford County, North Carolina

[G, growing season, May to September; NG, nongrowing season, October to April]

\begin{tabular}{|c|c|c|c|c|c|c|c|c|c|c|c|c|c|c|c|}
\hline \multirow{3}{*}{ Basin } & \multirow{2}{*}{\multicolumn{3}{|c|}{$\begin{array}{c}\text { Totai sediment yieid } \\
\text { (tons per acre per } \\
\text { year) }\end{array}$}} & \multicolumn{12}{|c|}{ Total nutrient yield (pounds per acre per year) } \\
\hline & & & & \multicolumn{3}{|c|}{ Phosphorus } & \multicolumn{3}{|c|}{$\begin{array}{l}\text { Ammonia and } \\
\text { organic nitrogen }\end{array}$} & \multicolumn{3}{|c|}{ Nitrlte pius nitrate } & \multicolumn{3}{|c|}{ Nitrogen } \\
\hline & $\mathbf{G}$ & NG & Totai & $\mathbf{G}$ & NG & Total & $\mathbf{G}$ & NG & Total & $\mathbf{G}$ & NG & Totai & $\mathbf{G}$ & NG & Totai \\
\hline $\begin{array}{l}\text { Standard land-management } \\
\text { practices. }\end{array}$ & 9.7 & 3.1 & 12.8 & 2.11 & 1.32 & 3.43 & 6.9 & 3.70 & 10.6 & 2.00 & 1.22 & 3.22 & 8.9 & 4.92 & 13.8 \\
\hline $\begin{array}{l}\text { Conservation land- } \\
\text { management practices. }\end{array}$ & 4.0 & 1.6 & 5.6 & 1.08 & .97 & 2.05 & 4.91 & 4.20 & 9.11 & 1.28 & 1.36 & 2.64 & 6.19 & 5.56 & 11.75 \\
\hline 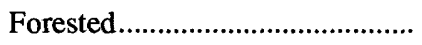 & .09 & .57 & .66 & .07 & .37 & .44 & .55 & 2.33 & 2.88 & .17 & .23 & .40 & .72 & 2.56 & 3.28 \\
\hline
\end{tabular}

observed in the CLM basin. Suspended-sediment particle sizes in surface water from the mixed land-use basin were larger than those observed in the row-crop basins. This result was expected because Candy Creek, in the mixed land-use basin, is a larger, higher energy stream than streams draining the row-crop basins.

\section{Sediment Yields}

Suspended-sediment yields are a direct means of assessing the effects of land-management practices on erosion. The primary purpose of CLM practices is to reduce soil erosion, which is reflected in reduced sediment yield. The yields for the row-crop basins can be put into a larger frame of reference with comparison to yields estimated for the mixed land-use and the forested basins.

An earlier analysis by Hill (1991) evaluated and compared sediment yields for the row-crop basins for June 1985 through September 1987. Hill used regression analysis to evaluate growing season and nongrowing season yields and reported mean growing season (May-September) yields of 1.2 tons per acre for the CLM basin and 7.9 tons per acre for the SLM basin. The nongrowing season (October-April) yields were 1.6 tons per acre for the CLM basin and 11.9 tons per acre for the SLM basin. Total annual yields reported by Hill were 2.7 tons per acre for the CLM basin and 20 tons per acre for the SLM basin.

Sediment yields for 18 North Carolina forested Piedmont basins were reported by Simmons and Heath (1982) and by Caldwell (1992). Sediment yields for the relatively undisturbed forested basins ranged from 0.05 to 0.14 ton per acre per year.

In a multivariate regression analysis of sediment yields from 25 rural basins in the North Carolina

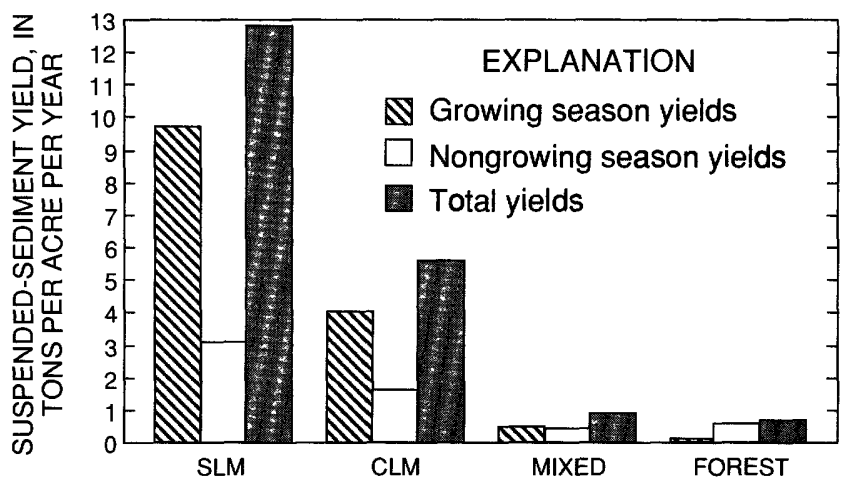

Figure 7. Yields of suspended sediment in surface water at the four study basins, 1985-90, Guilford County, North Carolina. SLM, standard land-management practices basin; CLM, conservation land-management practices basin; MIXED, mixed land-use basin, FOREST, forested basin.

Piedmont, Calvo-Alvarado (1990) developed a generalized regression equation for predicting mean annual suspended-sediment yield. The variables in the equation included basin mean elevation, drainage density, estimated mean annual gross erosion (Wischmeier and Smith, 1978), paved road density, unpaved road density, and percentage of watershed area draining to ponds. The mean suspended-sediment yield for the 25 Piedmont basins examined in the Calvo-Alvarado analysis was 0.05 ton per acre per year and ranged from 0.01 to 0.1 ton per acre per year.

Results from this $1985-90$ study indicate that the sediment yields for the SLM basin were higher than those observed for the other basins for the growing and nongrowing seasons. Suspended-sediment yields for the four study basins are listed in table 10 and shown graphically in figure 7 .

The general pattern observed in the comparison of suspended-sediment concentrations (fig. 6D) is also evident in yield comparisons. The SLM basin had the 
greatest sediment yields, followed by the CLM basin, and then the mixed land-use basin; the forested basin had the smallest sediment yields. This pattern was also evident in yields for the growing season (MaySeptember) except for a reversal of the relative rank for the mixed land-use and forested basins. The total annual sediment yield for the SLM basin was 12.7 tons per acre, which is 2.3 times the 5.6 tons per acre yield for the CLM basin, 14.1 times the 0.90 ton per acre yield for the mixed land-use basin, and 19.5 times the 0.65 ton per acre yield for the forested basin.

The observed differences between suspendedsediment yields for the two row-crop basins are evidence that CLM practices effectively reduce soil erosion. Although sediment yields for the CLM basin are higher than those observed for the mixed land-use and forested basins, they are lower than those observed for the SLM basin.

\section{Nutrients}

Nitrogen, phosphorus, and potassium are essential to plant life and are common components of fertilizer. During this study, fertilizer and lime were periodically applied to crops and grasses in the rowcrop basins. Applications to crops were made primarily in the spring and peaked in May (fig. 8). Fertilizer applications in January, February, October, and November were primarily for winter cover grasses in the waterways. In the CLM basin, most of the fertilizer was applied in March and April, whereas in the SLM basin most was applied in May and June. The number of fertilizer and lime applications in the CLM basin was 5 percent greater overall than in the SLM basin (fig. 9).

\section{Nitrogen Concentrations}

Nitrogen exists in inorganic and organic forms in natural waters. Inorganic forms of nitrogen are ammonia, nitrite, and nitrate nitrogen.

Concentrations of nitrogen in natural waters are generally transient because of oxidation of ammonia nitrogen to nitrite and nitrate by aerobic bacteria and the uptake of oxidized forms of nitrogen by plants. Weiss and others (1973) considered concentrations of total ammonia nitrogen greater than $0.5 \mathrm{mg} / \mathrm{L}$ in lakes indicative of animal or human contamination. Total nitrogen concentrations greater than $0.3 \mathrm{mg} / \mathrm{L}$ indicate the potential for nuisance growth of algae (Sawyer, 1947; Sakamoto, 1966; Vollenweider, 1971).

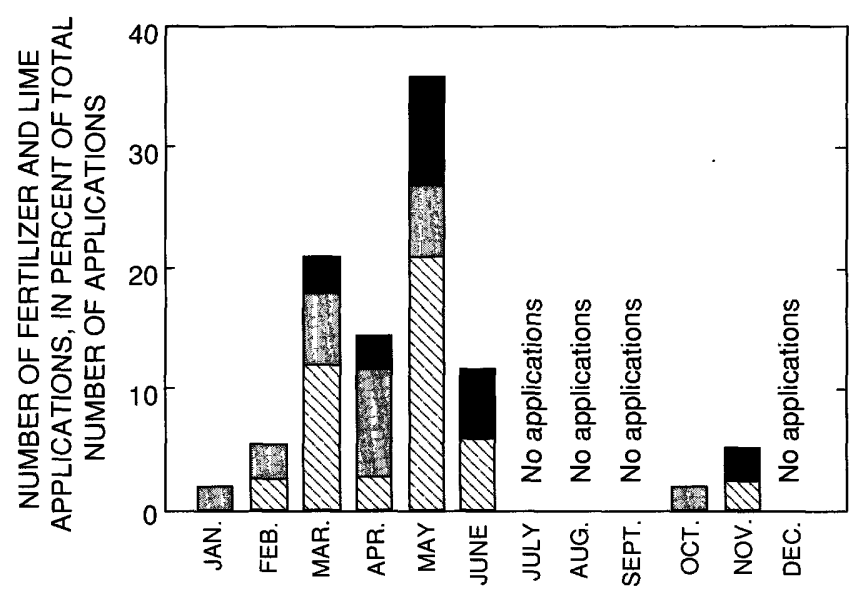

\section{EXPLANATION}

Standard land-management practices basin

D. Conservation land-management practices basin

Both basins

Figure 8. Distribution of fertilizer and lime applications, by month, at the two row-crop basins, 1985-90, Guilford County, North Carolina.

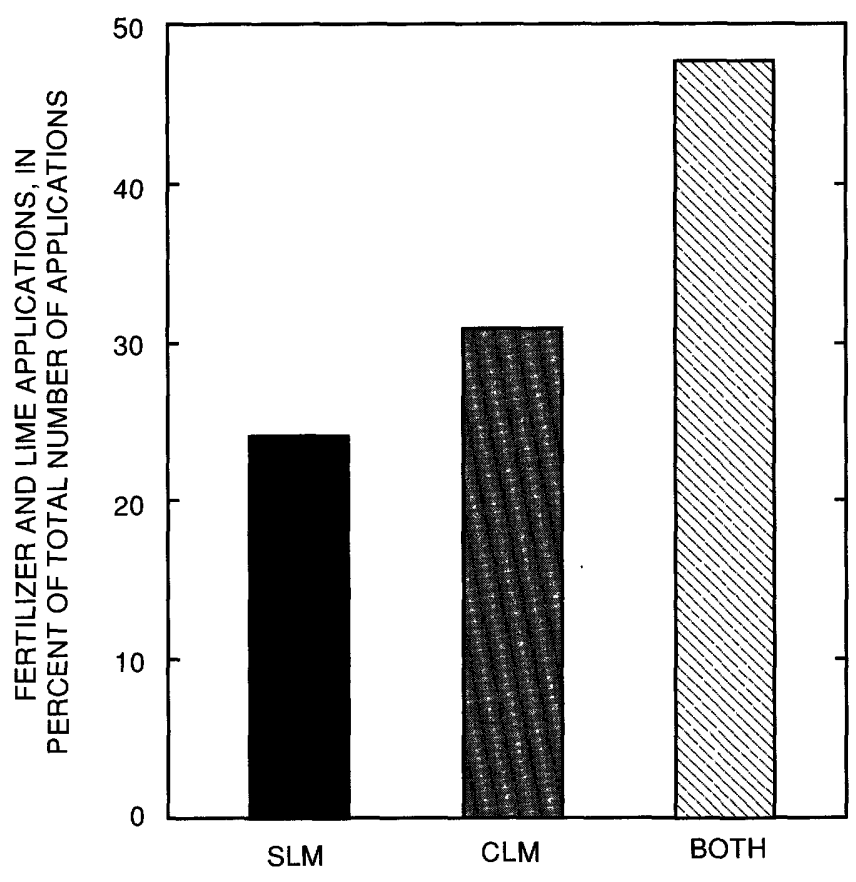

Figure 9. Percentage of fertilizer and lime applications at the standard land-management (SLM) practices basin, at the conservation land-management (CLM) practices basin, and at both (BOTH) basins, 1985-90, Guilford County, North Carolina. 
Simmons and Heath (1982) reported the ranges of nitrogen concentrations in surface water from 23 streams in forested and rural basins in the North Carolina Piedmont and Blue Ridge provinces as follows: ammonia nitrogen, $0.00-0.02 \mathrm{mg} / \mathrm{L}$; organic nitrogen, $0.02-0.69 \mathrm{mg} / \mathrm{L}$; and total nitrogen, $0.14-0.73 \mathrm{mg} / \mathrm{L}$.

Reported values for base flow, which is predominantly ground water, were as follows: ammonia nitrogen, $0.00-0.07 \mathrm{mg} / \mathrm{L}$; organic nitrogen, $0.00-0.51 \mathrm{mg} / \mathrm{L}$; and total nitrogen, $0.00-1.5 \mathrm{mg} / \mathrm{L}$.

Total ammonia nitrogen, total ammonia and organic nitrogen, and total nitrite plus nitrate nitrogen analyses were made of surface water, ground water, and soil water for the study basins and of precipitation for the station near the CLM basin. Total nitrogen as used in this report is defined as the sum of total ammonia and organic nitrogen and nitrite plus nitrate nitrogen. Nitrogen concentration statistics for surface water from the four study basins and precipitation samples from station 1 are listed in table 11. Nitrogen concentrations for soil water (unsaturated zone) and ground water (saturated zone) are summarized in table 12. Summaries of nitrogen concentrations in soil water at various depths are presented in table 13. The total number of analyses having concentrations at or below the analytical detection limit is listed in these tables. A log-probability regression procedure was used to estimate the mean and percentiles for constituents having concentrations less than the analytical detection limit. In general, concentrations of all forms of nitrogen were lower in ground water than in surface water, and a larger number of ground-water analyses had concentrations of nitrogen compounds less than the detection limit.

\section{Ammonia Nitrogen Concentrations}

Ammonia nitrogen concentrations in surface water from the CLM basin were significantly higher than those in surface water from the SLM basin, mixed land-use basin, and forested basin, and in precipitation (fig. 10A; app. 4). Ammonia nitrogen concentrations in surface water from the SLM basin were significantly higher than those in surface water from the forested basin. Ammonia nitrogen concentrations in surface water from the mixed land-use basin were significantly higher than those for the forested basin, and the ammonia nitrogen concentrations in surface water from the forested basin were significantly lower than those in precipitation.
The ammonia nitrogen concentrations in surface waters in the four basins indicate that farming activities increase concentrations of ammonia nitrogen in surface water. The CLM basin showed particularly high ammonia nitrogen levels in surface water from the basin, possibly because of higher fertilizer application rates and, in particular, nongrowing season fertilization of the grassed waterways and grass strips in this basin. Precipitation is an important source of total ammonia nitrogen in all of the study basins. High ammonia nitrogen in precipitation can be caused by emissions from the combustion of fossil fuels.

Although it seems that ammonia nitrogen concentrations increase with depth through the soil profile, concentrations in ground water are not significantly different from concentrations in soil water (app. 5 ). The lower nitrogen concentrations in shallow soils are probably due to nitrogen uptake by plants. Ammonia nitrogen concentrations in ground water and soil water were significantly lower than concentrations in surface water (app. 6). Total ammonia nitrogen concentrations in ground water, and in soil water at 3-, 6-, and 9-foot depths for the row-crop basins are shown in figure 10B. The differences in ammonia nitrogen concentrations for soil water at these different depths were not significant (app. 7).

These results indicate that although farming practices might cause some elevated ammonia nitrogen concentrations in soil, there was no demonstrable difference between the effects of different landmanagement practices on concentrations of ammonia nitrogen in soil water and ground water. Concentrations of ammonia nitrogen in ground water probably are lower than those in surface water because of nitrification in the soil zone.

\section{Total Ammonia and Organic Nitrogen Concentrations}

Ammonia and organic nitrogen concentrations in surface water from the row-crop basins and the mixed land-use basin were significantly higher than those in surface water from the forested basin and in precipitation (fig. 10C; app. 4). However, concentrations in surface water for the row-crop and mixed land-use basins were not significantly different from each other. Ammonia and organic nitrogen concentrations in surface water from the forested basin were significantly higher than those in precipitation.

These results provide evidence that farming activities increase the concentrations of ammonia and organic nitrogen in surface water, but that there is no 
Table 11. Summary of analyses of the major plant nutrients in surface-water and precipitation samples collected from the four study basins, 1985-90, Guilford County, North Carolina

[mg/L, milligram per liter; $\mathrm{N}$, nitrogen; $\mathrm{P}$, phosphorus; - , no data]

\begin{tabular}{|c|c|c|c|c|c|c|c|c|}
\hline \multirow{3}{*}{ Constituent } & \multicolumn{2}{|c|}{ Number of samples } & \multicolumn{6}{|c|}{ Concentration (mg/L) } \\
\hline & \multirow{2}{*}{ Total } & \multirow{2}{*}{$\begin{array}{l}\text { At or below } \\
\text { detection } \\
\text { iimit }\end{array}$} & \multirow{2}{*}{ Mean } & \multirow{2}{*}{ Minimum } & \multicolumn{3}{|c|}{ At indicated percentile } & \multirow{2}{*}{ Maximum } \\
\hline & & & & & $25^{\text {th }}$ & $50^{\text {th }}$ & $75^{\text {th }}$ & \\
\hline \multicolumn{9}{|c|}{ Standard land-management practices basin—Smith Branch upper tributary $(\mathbf{0 2 0 9 4 3 7 8 2 5})^{1}$} \\
\hline Total ammonia nitrogen, as $\mathrm{N}$ & 157 & 0 & 0.27 & 0.01 & 0.08 & 0.16 & 0.32 & 4.4 \\
\hline Total ammonia and organic nitrogen, as $\mathbf{N}$....... & 157 & 6 & 4.8 & .20 & .80 & 1.6 & 5.6 & 45 \\
\hline 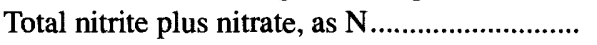 & 157 & 9 & 21.1 & .10 & 2.37 & 2.70 & ${ }^{2} 1.5$ & 7.2 \\
\hline Total nitrogen, as N & 157 & 9 & 25.9 & .30 & 21.8 & 23.3 & 26.2 & 47.8 \\
\hline Dissolved orthophosphorus, as $\mathrm{P}$ & 157 & 36 & 2.10 & .01 & ${ }^{2} .01$ & 2.04 & 2.13 & 1.6 \\
\hline 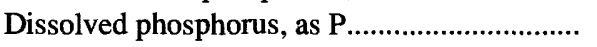 & 38 & 3 & 2.10 & .01 & ${ }^{2} .03$ & 2.10 & 2.15 & .31 \\
\hline Total phosphorus, as $\mathrm{P}$ & 139 & 3 & 1.4 & .01 & .25 & .59 & 1.2 & 10 \\
\hline Total potassium .................................................. & 55 & 0 & 10 & 3 & 7 & 9 & 12 & 25 \\
\hline \multicolumn{9}{|c|}{ Conservation land-management practices basin-Smith Branch lower tributary $(0209437850)^{1}$} \\
\hline 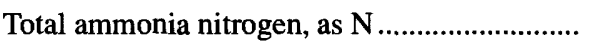 & 140 & 0 & 0.50 & 0.01 & 0.13 & 0.21 & 0.37 & 5.3 \\
\hline Total ammonia and organic nitrogen, as $\mathrm{N}$....... & 138 & 3 & 2.4 & .20 & 1.0 & 1.5 & 3.1 & 13 \\
\hline Total nitrite plus nitrate, as $\mathrm{N}$ & 140 & 9 & 2.76 & .10 & 2.26 & 2.50 & 2.90 & 4.5 \\
\hline Total nitrogen, as $\mathrm{N}$ & 138 & 9 & 23.1 & .50 & 21.5 & 22.3 & 24.1 & 14 \\
\hline 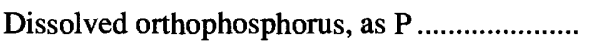 & 137 & 11 & 2.21 & .01 & 2.04 & 2.10 & 2.24 & 2.3 \\
\hline 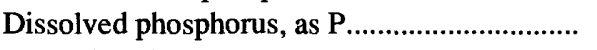 & 20 & 0 & .10 & .03 & .06 & .10 & .13 & .27 \\
\hline Total phosphorus, as $\mathrm{P}$ & 138 & 0 & .55 & .05 & .22 & .37 & .55 & 4.4 \\
\hline 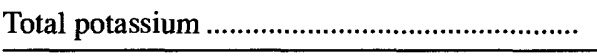 & 43 & 0 & 6.5 & .9 & 5 & 6 & 8 & 12 \\
\hline \multicolumn{9}{|c|}{ Mixed land-use basin-Candy Creek $(0209331325)^{1}$} \\
\hline 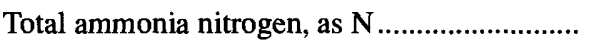 & 129 & 2 & 0.20 & 0.01 & 0.07 & 0.15 & 0.31 & 0.89 \\
\hline Total ammonia and organic nitrogen, as $\mathrm{N}$....... & 129 & 1 & 2.3 & .20 & 1.00 & 1.50 & 3.20 & 13 \\
\hline 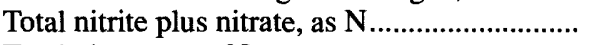 & 129 & 0 & .67 & .10 & .40 & .50 & .80 & 3.7 \\
\hline Total nitrogen, as $\mathrm{N}$ & 129 & 1 & 3.0 & .70 & 1.50 & 2.20 & 3.70 & 14 \\
\hline Dissolved orthophosphorus, as P........................ & 129 & 2 & .18 & .01 & .06 & .16 & .25 & .61 \\
\hline 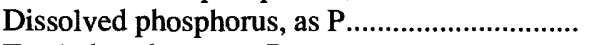 & 40 & 1 & .09 & .01 & .030 & .080 & .16 & .23 \\
\hline Total phosphorus, as $\mathrm{P}$ & 129 & 0 & .62 & .03 & .23 & .48 & .81 & 4.2 \\
\hline Total potassium & 59 & 0 & 4.9 & 1 & 3 & 5 & 6 & 13 \\
\hline \multicolumn{9}{|c|}{ Forested basin-Brooks Lake tributary $(0209330990)^{1}$} \\
\hline Total ammonia nitrogen, as $\mathrm{N}$................................. & 79 & 8 & ${ }^{2} 0.05$ & 0.01 & 20.02 & ${ }^{2} 0.04$ & 20.07 & 0.23 \\
\hline Total ammonia and organic nitrogen, as $\mathrm{N}$...... & 78 & 0 & 1.2 & .20 & .40 & .80 & 1.4 & 10 \\
\hline 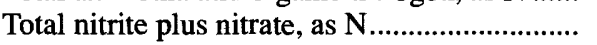 & 78 & 45 & 2.13 & .07 & 2.04 & ${ }^{2} .08$ & 2.16 & .60 \\
\hline 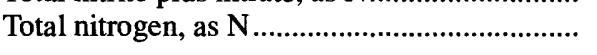 & 77 & 45 & 21.4 & .30 & 2.60 & 21.0 & 21.5 & 10 \\
\hline 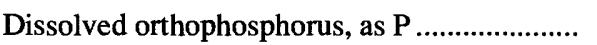 & 78 & 1 & .06 & .01 & .03 & .05 & .09 & .19 \\
\hline 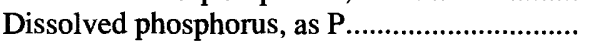 & 25 & 0 & .08 & .03 & .06 & .08 & .09 & .13 \\
\hline Total phosphorus, as $\mathrm{P}$ & 78 & 0 & .16 & .04 & .07 & .11 & .18 & 1.1 \\
\hline 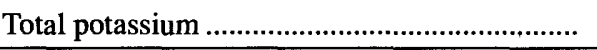 & 36 & 0 & 2.0 & .8 & 2 & 2 & 2 & 4 \\
\hline \multicolumn{9}{|c|}{ Precipitation station 1} \\
\hline Total ammonia nitrogen, as $\mathrm{N}$................................. & 28 & 0 & 0.18 & 0.02 & 0.08 & 0.14 & 0.30 & 0.53 \\
\hline Total ammonia and organic nitrogen, as $\mathrm{N}$...... & 28 & 2 & .58 & .10 & .33 & .60 & .80 & 1.1 \\
\hline 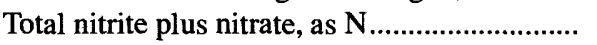 & 28 & 1 & .46 & .10 & .21 & .40 & .58 & 1.2 \\
\hline Total nitrogen, as $\mathrm{N}$ & 28 & 2 & 1.0 & .20 & .65 & 1.0 & 1.20 & 2.30 \\
\hline Dissolved orthophosphorus, as P ....................... & 28 & 10 & 2.02 & .01 & ${ }^{2} .01$ & ${ }^{2} .03$ & 2.03 & .10 \\
\hline 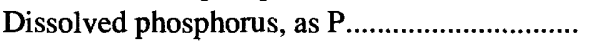 & - & - & - & - & - & - & - & - \\
\hline Total phosphorus, as $\mathrm{P}$ & 28 & 3 & .04 & .01 & .01 & .03 & .04 & .19 \\
\hline Total potassium & - & - & - & - & - & - & - & - \\
\hline
\end{tabular}

${ }^{1}$ U.S. Geological Survey downstream order identification number.

${ }^{2}$ Value is estimated by using a log-probability regression to predict the values of data below the detection limit. 
Table 12. Summary of analyses of the major plant nutrients in ground-water samples collected from wells and soil-water samples collected from lysimeters in the row-crop basins, 1985-90, Guilford County, North Carolina

[mg/L, milligram per liter; N, nitrogen; P, phosphorus; - , no data]

\begin{tabular}{|c|c|c|c|c|c|c|c|c|}
\hline \multirow{3}{*}{ Constituent } & \multicolumn{2}{|c|}{ Number of samples } & \multicolumn{6}{|c|}{ Concentration (mg/L) } \\
\hline & \multirow{2}{*}{ Total } & \multirow{2}{*}{$\begin{array}{c}\text { At or below } \\
\text { detection } \\
\text { limit }\end{array}$} & \multirow{2}{*}{ Mean } & \multirow{2}{*}{ Minimum } & \multicolumn{3}{|c|}{ At indicated percentlle } & \multirow{2}{*}{ Maximum } \\
\hline & & & & & $25^{\text {th }}$ & $50^{\text {th }}$ & $75^{\text {th }}$ & \\
\hline \multicolumn{9}{|c|}{ Standard land-management practices basin-Soil water } \\
\hline 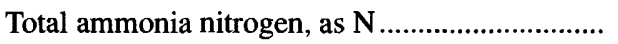 & 70 & 26 & ${ }^{1} 0.07$ & 0.01 & ${ }^{1} 0.008$ & ${ }^{1} 0.03$ & ${ }^{1} 0.07$ & 0.72 \\
\hline Total ammonia and organic nitrogen, as $\mathrm{N}$.......... & 68 & 16 & ${ }^{1} .66$ & 1.20 & 1.20 & 1.35 & .70 & 5.60 \\
\hline 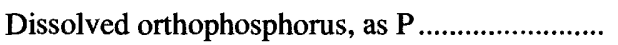 & 70 & 29 & ${ }^{1} .01$ & .001 & ${ }^{1} .002$ & 1.006 & 1.02 & .07 \\
\hline 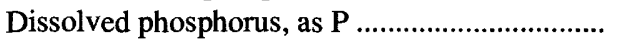 & - & - & - & - & 一 & - & - & - \\
\hline Total phosphorus, as $\mathrm{P}$ & 69 & 12 & .07 & .01 & .01 & .03 & .06 & 1.6 \\
\hline \multicolumn{9}{|c|}{ Standard land-management practices basin-Ground water } \\
\hline 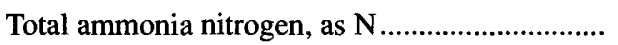 & 26 & 3 & ${ }^{1} 0.06$ & 0.01 & ${ }^{1} 0.02$ & ${ }^{1} 0.03$ & ${ }^{1} 0.07$ & 0.65 \\
\hline Dissolved orthophosphorus, as P............................ & 26 & 15 & ${ }^{1} .009$ & .01 & 1.002 & 1.006 & ${ }^{1} .01$ & .94 \\
\hline 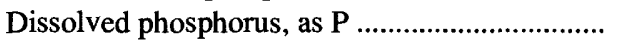 & 26 & 4 & 1.01 & .001 & ${ }^{1} .005$ & 1.01 & 1.02 & .05 \\
\hline Total phosphorus, as $\mathrm{P}$ & 26 & 5 & 1.03 & .01 & 1.009 & ${ }^{1} .02$ & ${ }^{1} .023$ & .17 \\
\hline \multicolumn{9}{|c|}{ Conservation land-management practices basin-Soil water } \\
\hline Total ammonia nitrogen, as $\mathrm{N} . . . . . . . . . . . .$. & 118 & 30 & ${ }^{1} 0.06$ & 0.01 & ${ }^{1} 0.01$ & ${ }^{1} 0.03$ & ${ }^{1} 0.07$ & ${ }^{1} 0.66$ \\
\hline Total ammonia and organic nitrogen, as $\mathbf{N}$.......... & 117 & 26 & 1.59 & .20 & 1.20 & ${ }^{1} .40$ & 1.80 & 13.4 \\
\hline Total nitrite plus nitrate, as $\mathrm{N}$ & 118 & 67 & 1.57 & .01 & 1.10 & 1.10 & 1.60 & 14.5 \\
\hline Total nitrogen, as $\mathrm{N}$ & 117 & 67 & 11.2 & .30 & 1.30 & 1.70 & ${ }^{1} 1.7$ & 15.5 \\
\hline 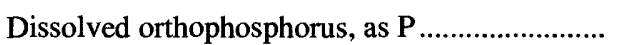 & 118 & 51 & 1.02 & .001 & 1.002 & ${ }^{1} .007$ & 1.02 & 1.55 \\
\hline 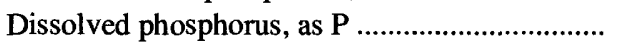 & - & - & - & - & - & - & - & - \\
\hline \multicolumn{9}{|c|}{ Conservation land-management practices basin-Ground water } \\
\hline 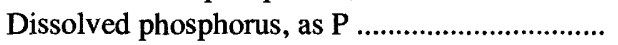 & 26 & 2 & ${ }^{1} .02$ & .001 & ${ }^{1} .003$ & 1.01 & ${ }^{1} .02$ & .14 \\
\hline Total phosphorus, as $\mathrm{P}$ & 26 & 4 & ${ }^{1} .05$ & .01 & ${ }^{1} .01$ & 1.02 & ${ }^{1} .03$ & .32 \\
\hline
\end{tabular}

${ }^{1}$ Value is estimated by using a log-probability regression to predict the values of data below the detection limit.

appreciable difference in the effects of different landmanagement practices on those concentrations. Leaf litter is probably an important source of organic nitrogen in surface water from the forested basin.

Total ammonia and organic nitrogen concentrations in soil water for the SLM basin were significantly higher than those in ground water (fig. 10D; app. 5). At both row-crop basins, the concentrations at the 3-foot depth were significantly lower than those at the 6-foot and 9-foot depths. However, the concentrations at the 6-foot depth were significantly higher than those at the 9-foot depth for the SLM basin but not significantly different from the concentrations at the 9foot depth for the CLM basin. As was observed with ammonia nitrogen concentrations, ammonia and organic nitrogen concentrations were lowest just below the root zone (3-foot depth) and in ground water. Ammonia and organic nitrogen concentrations in ground water and soil water were significantly lower than those in surface water from the row-crop basins (app. 6). 
Table 13. Summary of analyses of the major plant nutrients in soil-water samples collected from lysimeters at 3-, 6-, and 9foot depths in the row-crop basins, 1985-90, Guilford County, North Carolina

[mg/L, milligram per liter; $\mathrm{N}$, nitrogen; $\mathrm{P}$, phosphorus]

\begin{tabular}{|c|c|c|c|c|c|c|c|c|}
\hline \multirow{3}{*}{ Constituent } & \multicolumn{2}{|c|}{ Number of samples } & \multicolumn{6}{|c|}{ Concentration $(\mathrm{mg} / \mathrm{L})$} \\
\hline & \multirow{2}{*}{ Total } & \multirow{2}{*}{$\begin{array}{l}\text { At or below } \\
\text { detectlon } \\
\text { limit }\end{array}$} & \multirow{2}{*}{ Mean } & \multirow{2}{*}{ Minimum } & \multicolumn{3}{|c|}{ At indicated percentlle } & \multirow{2}{*}{ Maximum } \\
\hline & & & & & $25^{\text {th }}$ & $50^{\text {th }}$ & $75^{\text {th }}$ & \\
\hline 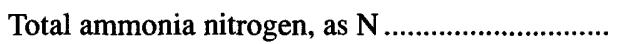 & 60 & 25 & ${ }^{1} 0.05$ & 0.01 & ${ }^{1} 0.01$ & ${ }^{1} 0.02$ & ${ }^{1} 0.06$ & 0.72 \\
\hline Total ammonia and organic nitrogen, as $\mathrm{N}$.......... & 59 & 16 & 1.56 & .20 & 1.15 & 1.30 & ${ }^{1} .63$ & 2.7 \\
\hline 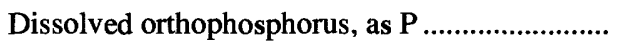 & 60 & 29 & ${ }^{1} .01$ & .001 & ${ }^{1} .002$ & 1.005 & 1.02 & .06 \\
\hline Total phosphorus, as $\mathrm{P}$ & 59 & 12 & ${ }^{1} .04$ & .01 & 1.01 & 1.03 & ${ }^{1} .05$ & .16 \\
\hline \multicolumn{9}{|c|}{ Soil water at 6-foot depth in the standard land-management practices basin } \\
\hline 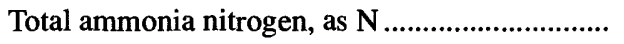 & 5 & 1 & 0.08 & 0.01 & 0.04 & 0.07 & 0.14 & 0.15 \\
\hline Total ammonia and organic nitrogen, as $\mathbf{N}$.......... & 4 & 0 & 2.1 & .70 & .73 & .95 & 4.5 & 5.6 \\
\hline Total phosphorus, as $\mathrm{P}$ & 5 & 0 & .42 & .04 & .05 & .14 & .93 & 1.6 \\
\hline \multicolumn{9}{|c|}{ Soil water at 9-foot depth in the standard land-management practices basin } \\
\hline 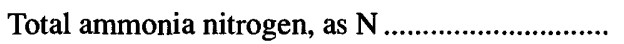 & 5 & 0 & 0.41 & 0.23 & 0.29 & 0.39 & 0.53 & 0.57 \\
\hline Total ammonia and organic nitrogen, as $\mathrm{N}$......... & 5 & 0 & .98 & .70 & .70 & 1.0 & 1.3 & 1.4 \\
\hline Total nitrite plus nitrate, as $\mathrm{N}$ & 5 & 3 & .30 & .10 & .10 & .10 & .60 & 1.1 \\
\hline Total nitrogen, as $\mathrm{N}$ & 5 & 3 & 1.3 & .80 & .95 & 1.2 & 1.7 & 1.8 \\
\hline Dissolved orthophosphorus, as P......................... & 5 & 0 & .05 & .02 & .02 & .04 & .09 & .10 \\
\hline Total phosphorus, as $\mathrm{P}$ & 5 & 0 & .13 & .05 & .08 & .12 & .18 & .21 \\
\hline \multicolumn{9}{|c|}{ Soil water at 3-foot depth in the conservation land-management practices basin } \\
\hline Total ammonia nitrogen, as $\mathrm{N}$................................. & 68 & 22 & ${ }^{10} 0.04$ & 0.01 & 10.008 & ${ }^{1} 0.02$ & 10.05 & 0.66 \\
\hline 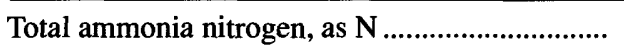 & 42 & 8 & 10.06 & 0.01 & ${ }^{1} 0.01$ & 10.04 & 10.09 & 0.21 \\
\hline Total ammonia and organic nitrogen, as $\mathrm{N}$.......... & 42 & 6 & 1.71 & .20 & 1.20 & 1.50 & 1.0 & 3.4 \\
\hline 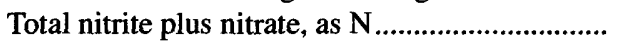 & 42 & 27 & 1.50 & .01 & 1.009 & 1.04 & 1.25 & 4.5 \\
\hline Total nitrogen, as $\mathrm{N}$ & 42 & 27 & ${ }^{1} 1.2$ & .30 & 1.30 & 1.75 & 11.5 & 5.5 \\
\hline Dissolved orthophosphorus, as P ............................ & 42 & 12 & 1.02 & .001 & 1.006 & 1.01 & 1.02 & .09 \\
\hline Total phosphorus, as $\mathrm{P}$ & 42 & 2 & .10 & .01 & $\cdot 02$ & .06 & ${ }^{1} .09$ & 1.2 \\
\hline \multicolumn{9}{|c|}{ Soil water at 9-foot depth in the conservation land-management practices basin } \\
\hline Total ammonia nitrogen, as $\mathrm{N}$............................... & 8 & 0 & 0.19 & 0.06 & 0.08 & 0.17 & 0.18 & 0.58 \\
\hline Total ammonia and organic nitrogen, as $\mathrm{N}$.......... & 8 & 0 & 1.2 & .40 & .60 & 1.1 & 1.6 & 2.6 \\
\hline Total nitrite plus nitrate, as $\mathrm{N}$ & 8 & 7 & .33 & .10 & .10 & .10 & .10 & 2.0 \\
\hline Total nitrogen, as $\mathrm{N}$ & 8 & 7 & 1.5 & .50 & .70 & 1.3 & 2.5 & 3.1 \\
\hline 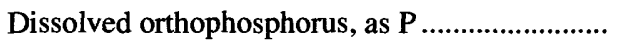 & 8 & 3 & 1.10 & .01 & ${ }^{1} .001$ & ${ }^{1} .02$ & 1.14 & .55 \\
\hline Total phosphorus, as $\mathrm{P}$ & 8 & 0 & .18 & .02 & .08 & .11 & .24 & .62 \\
\hline
\end{tabular}

\footnotetext{
${ }^{1}$ Value is estimated by using a log-probability regression to predict the values of data below the detection limit.
} 

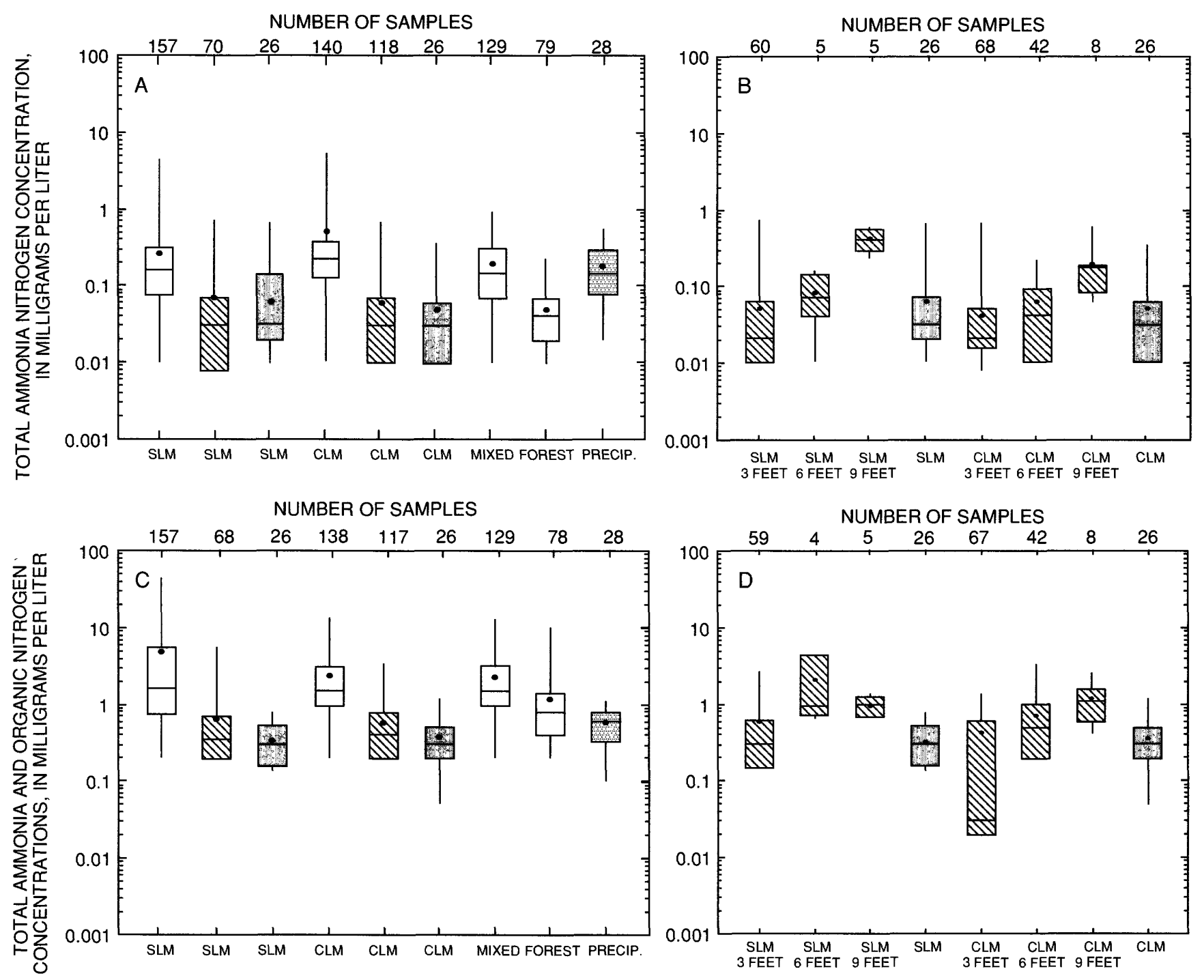

\section{EXPLANATION}
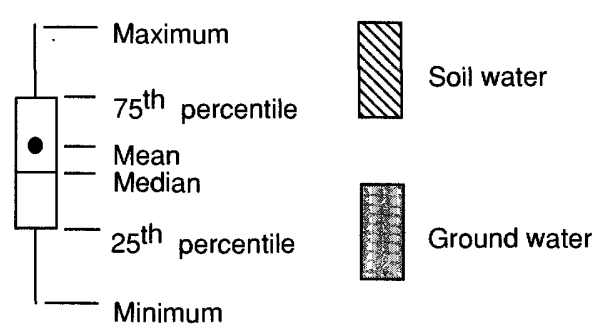

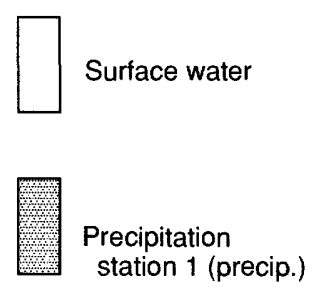

North Carolina. SLM, standard land-management practices basin; CLM, conservation land-management practices basin; MIXED, mixed land-use basin, FOREST, forested basin. Depths indicated represent feet below land surface.
These results indicate that farming practices probably cause elevated concentrations of total ammonia and organic nitrogen in soil water; however, comparative soil-water data for the forested basin were not collected. Differences in ammonia and organic nitrogen concentrations in soil water and 

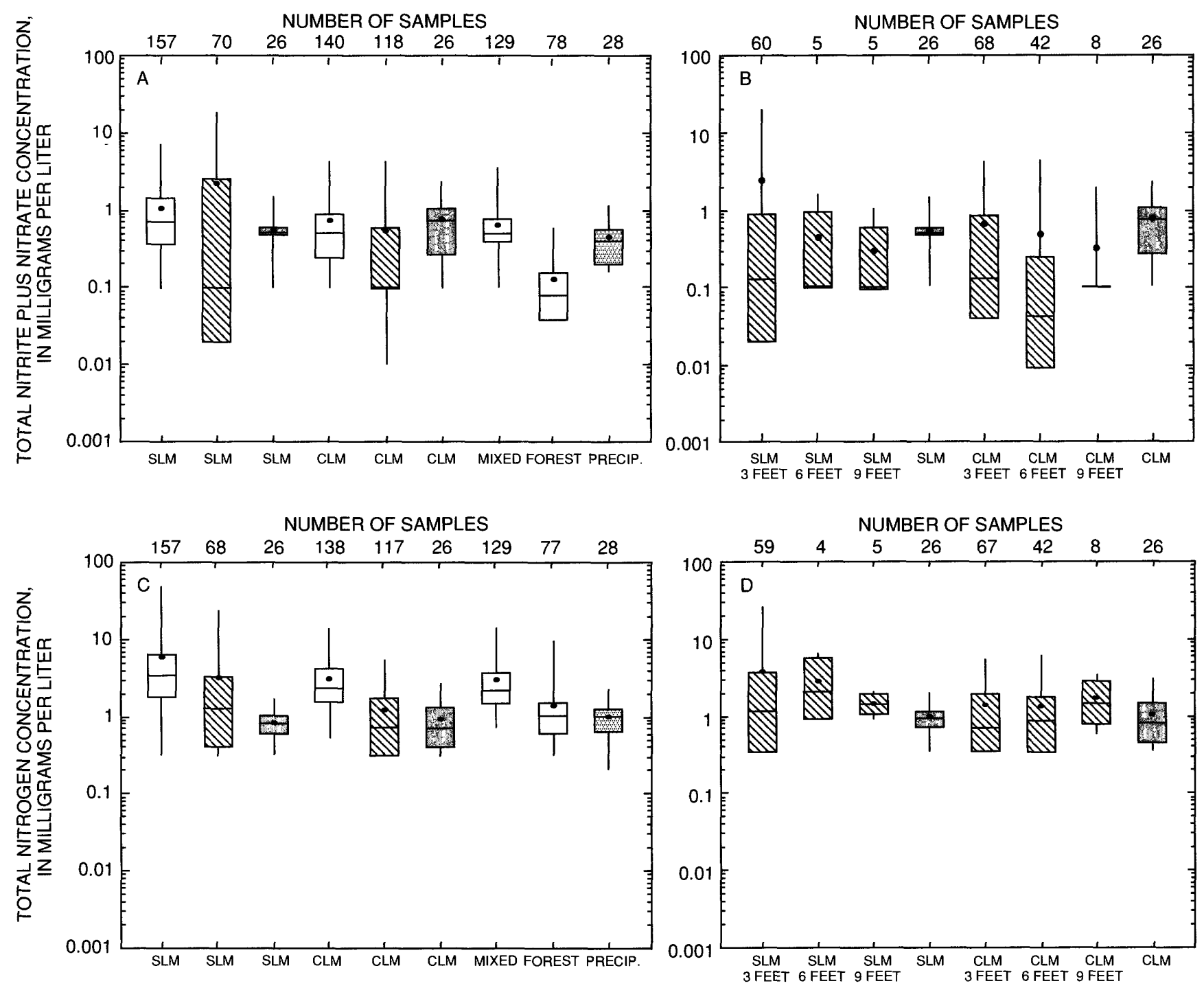

\section{EXPLANATION}

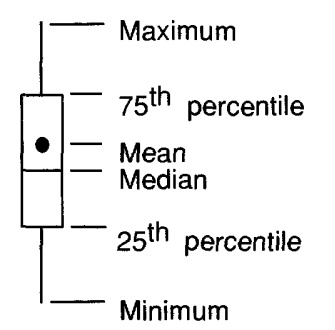

Figure 11. Summary of, $A$ and $B$, total nitrite plus nitrate concentrations and, $\mathrm{C}$ and $\mathrm{D}$, total nitrogen concentrations in surface water, soil water, and ground water and in precipitation, 1985-90, Guilford County, North Carolina.

ground water attributable to different landmanagement practices are not evident.

\section{Total Nitrite Plus Nltrate Concentrations}

Nitrite plus nitrate concentrations in surface water from the SLM basin were significantly higher
Soil water

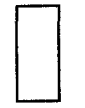
Surface water

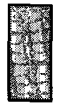

Ground water

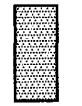

Precipitation station 1 (precip.)

SLM, standard land-management practices basin; CLM, conservation land-management practices basin; MIXED, mixed land-use basin, FOREST, forested basin. Depths indicated represent feet below land surface.

than those in surface water from all the other basins and in precipitation (fig. 11A; app. 4). Nitrite plus nitrate concentrations in surface water from the CLM basin were significantly higher than concentrations in surface water from the forested basin. Concentrations in surface water from the mixed land-use basin were 
significantly higher than those in surface water from the forested basin and in precipitation. As was observed with ammonia nitrogen, the nitrite plus nitrate concentrations in the forested basin surface water were significantly lower than those in precipitation.

These results indicate that farming activities, and SLM practices in particular, increase the concentrations of total nitrite plus nitrate in surface water. The nitrite plus nitrate concentrations were higher in the SLM basin than in the CLM basin, although the SLM basin received 14 percent fewer nitrogen fertilizer applications. In addition, the results indicate that precipitation was also an important source of total nitrite plus nitrate for surface water in the basin.

Nitrite plus nitrate concentrations in soil water and ground water in the SLM basin were significantly higher than concentrations in soil water for the CLM basin (fig. 11B). In particular, the nitrite plus nitrate concentrations at the 3-foot depth were significantly higher in the SLM basin than in the CLM basin (app. 7). Nitrite plus nitrate concentrations in ground water and soil water were significantly lower than those in surface water (app. 6).

These results demonstrate a significant difference in total nitrite plus nitrate concentrations in soil water and ground water between the SLM and CLM basins. The SLM basin had significantly higher nitrite plus nitrate concentrations in soil water and ground water than those in soil water and ground water in the CLM basin.

\section{Total Nitrogen Concentrations}

Total nitrogen concentrations were significantly higher in surface water from the SLM basin than in surface water from all the other basins, and in precipitation (fig. 11C; app. 4). Total nitrogen concentrations in surface water from the CLM basin and the mixed land-use basin were significantly higher than concentrations in surface water for the forested basin and precipitation. However, there was no significant difference between total nitrogen concentrations in the CLM and mixed land-use basins.

These results indicate that farming activities increase the concentration of total nitrogen in surface water. In this study, the basin farmed by using SLM practices had the highest mean concentration of total nitrogen in surface water.

Total nitrogen concentrations in soil water for the SLM basin were significantly higher than those in soil water and ground water in the CLM basin (fig. 11D). As observed for total nitrite plus nitrate concentrations, total nitrogen concentrations at the 3-foot depth were significantly higher in the SLM basin than in the CLM basin. Total nitrogen concentrations in ground water and soil water in the two row-crop basins were significantly lower than concentrations in surface water from these basins (app. 6).

These results indicate that total nitrogen concentrations in soil water are affected by land-management practices. The basin farmed by using SLM practices had higher total nitrogen concentrations in soil water than did the CLM basin.

The median total nitrogen concentration exceeded $0.30 \mathrm{mg} / \mathrm{L}$, which is considered by some investigators to be indicative of the potential for nuisance algal growth (Sawyer, 1947; Sakamoto, 1966; Vollenweider, 1971), in surface water at all four basins, in soil water and ground water in the two rowcrop basins, and in precipitation. Although land-use and land-management practices have a considerable effect on total nitrogen concentrations, the concentration of total nitrogen in precipitation is apparently high enough to support algal growth.

\section{Phosphorus Concentrations}

Various water-quality criteria have been cited for phosphorus concentration. The National Technical Advisory Committee (1968) recommended $0.05 \mathrm{mg} / \mathrm{L}$ total phosphorus (as $\mathrm{P}$ ) as the maximum limit for waters entering impoundments. Other sources (Sawyer, 1947; Sakamoto, 1966; and Vollenweider, 1971) have noted that total phosphorus concentrations higher than $0.01 \mathrm{mg} / \mathrm{L}$ in lakes promote nuisance algal growth. A concentration less than $0.1 \mathrm{mg} / \mathrm{L}$ is recommended by Mackenthum (1969) to prevent algal blooms in streams.

Simmons and Heath (1982) reported a range of $0.00-0.04 \mathrm{mg} / \mathrm{L}$ total phosphorus concentrations in surface water during stormflow from 23 streams in forested and rural basins in the North Carolina Piedmont and Blue Ridge provinces and $0.00-0.05 \mathrm{mg} / \mathrm{L}$ in base flow from these streams. Caldwell (1992) reported total phosphorus concentrations of $<0.01-$ $0.24 \mathrm{mg} / \mathrm{L}$ for surface water and $<0.01-0.07 \mathrm{mg} / \mathrm{L}$ for base flow from five streams in forested and rural basins of the Piedmont and Blue Ridge provinces.

Surface-water samples from the four study basins were analyzed for dissolved phosphorus, dissolved orthophosphorus, and total phosphorus 
concentrations. Soil-water and ground-water samples from the two row-crop basins and precipitation samples from station 1 near the CLM basin were analyzed for dissolved orthophosphorus and total phosphorus concentrations. Total phosphorus includes particulate and dissolved phosphorus and is the most commonly cited measure of phosphorus when effects on aquatic organisms are evaluated. Orthophosphate is the final dissociation product of the various forms of phosphorus in water.

A summary of the results of phosphorus analyses of surface-water samples from the four study basins and for precipitation samples is presented in table 11. A summary of phosphorus concentrations in soil water and ground water in the study basins is presented in table 12 , and phosphorus concentrations in soil water at depths of 3,6 , and 9 feet in the two rowcrop basins are summarized in table 13.

\section{Dissolved Phosphorus Concentrations}

Selected water samples were analyzed for dissolved phosphorus concentrations. Dissolved phosphorus concentrations for surface and ground water in the CLM and SLM basins and for surface water from the mixed land-use and forested basins are summarized in figure 12A. Although a significant difference between dissolved phosphorus concentrations in surface and ground water in the row-crop basins is indicated (app. 6), no other significant differences among dissolved phosphorus concentrations were identified.

\section{Dissolved Orthophosphorus Concentrations}

Dissolved orthophosphorus concentrations in surface water from the CLM basin were significantly higher than those in surface water from the other basins and in precipitation (fig. 12B; app. 4). Dissolved orthophosphorus concentrations in surface water from the SLM basin were significantly lower than those at the mixed land-use basin but higher than those at the forested basin and in precipitation. Concentrations of dissolved orthophosphorus in surface water from the mixed land-use basin were significantly higher than concentrations in surface water from the forested basin and in precipitation. Dissolved orthophosphorus concentrations in surface water from the forested basin were significantly higher than concentrations in precipitation.

These results indicate that farming activities, and CLM practices in particular, increase concentrations of dissolved orthophosphorus in surface water.
The results also indicate that precipitation is an important source of dissolved orthophosphorus for the basins.

Concentrations of dissolved orthophosphorus in soil water at a depth of 3 feet were significantly lower than concentrations at a depth of 9 feet for both rowcrop basins (fig. 12C; app. 7). This result is similar to that observed for total ammonia nitrogen concentrations. Dissolved orthophosphorus concentrations in ground water and soil water were significantly lower than those for surface water from the row-crop basins (app. 6).

The distribution of concentrations of dissolved orthophosphorus in soil water collected from the two row-crop basins indicates that farming activities probably caused elevated dissolved orthophosphorus concentrations in soil water. However, there were no significant differences in dissolved orthophosphorus concentrations in soil water or ground water between areas farmed using different land-management practices.

\section{Total Phosphorus Concentrations}

Total phosphorus concentrations in surface water from the SLM basin were significantly higher than those in precipitation and in surface water from other basins except the mixed land-use basin (fig. 13; app. 4). Total phosphorus concentrations in surface water from the CLM and the mixed land-use basins were significantly higher than concentrations in surface water from the forested basin and in precipitation. Concentrations of total phosphorus in surface water from the CLM basin were not significantly different from concentrations in surface water from the mixed land-use basin. This pattern of total phosphorus concentration distribution is similar to that observed for total nitrogen.

These results indicate that farming activities increase concentrations of total phosphorus in surface water. In this study, the basin farmed by using SLM practices had the highest total phosphorus concentrations in surface water. There were no significant differences among dissolved phosphorus concentrations in the four study basins. Therefore, the observed differences in total phosphorus concentrations among basins are primarily due to variation in particulate phosphorus concentrations. This variation could result from the higher sediment concentrations in the SLM basin because phosphorus is readily sorbed on sediment. However, part of the difference probably is 

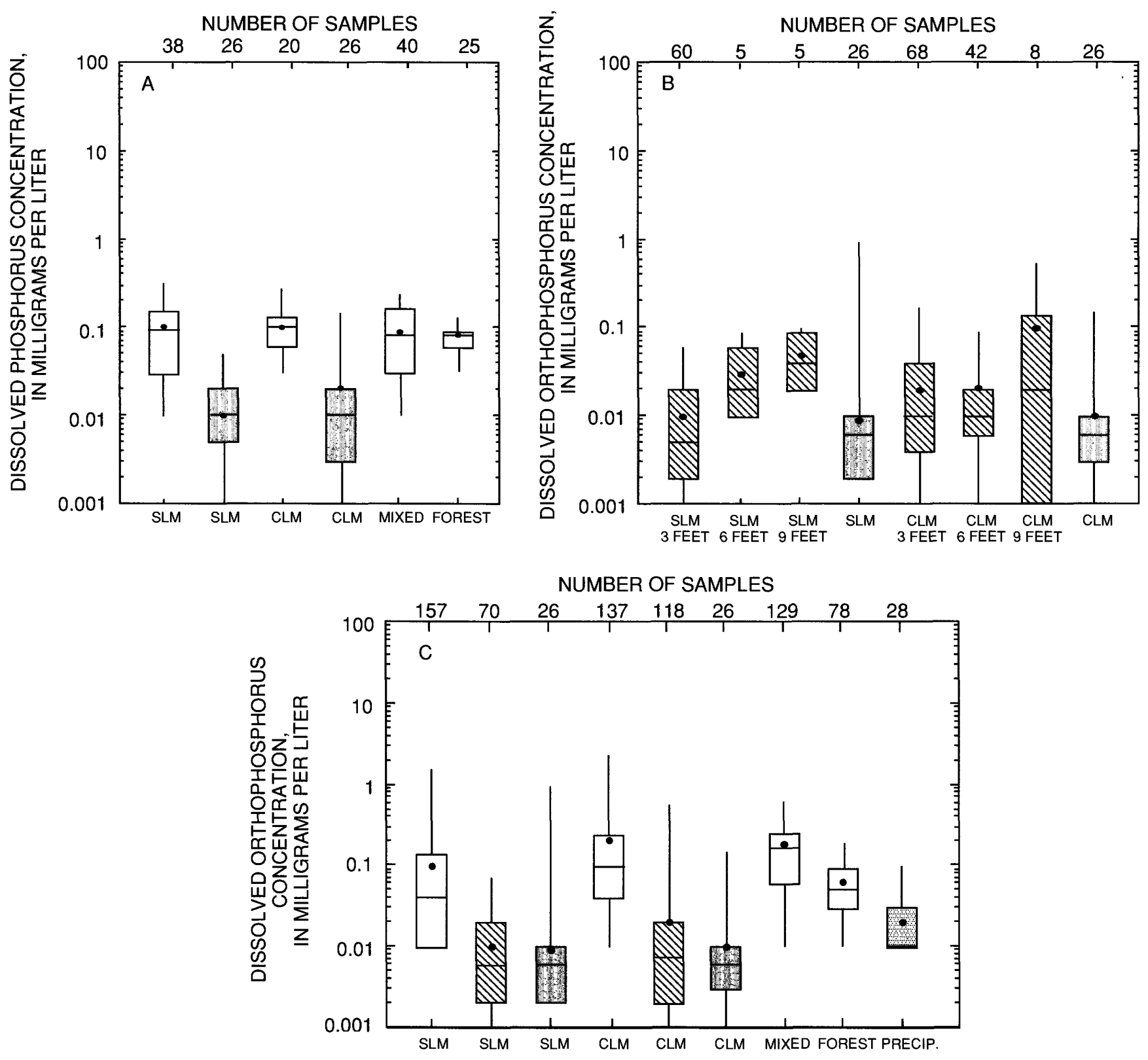

\section{EXPLANATION}

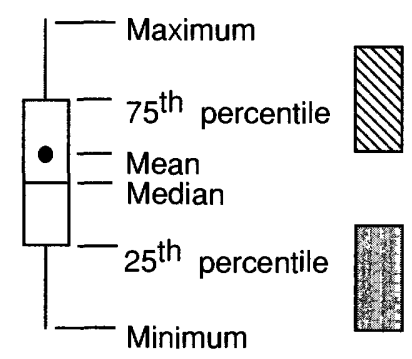

Soil water

Surface water

Ground water

Precipitation station 1 (precip.)

Figure 12. Summary of, A, dissolved phosphorus concentrations and, B and C, dissolved orthophosphorus concentrations in surface water, soil water, and ground water and in precipitation, 1985-90, Guilford County, North
Carolina. SLM, standard land-management practices basin; CLM, conservation land-management practices basin; MIXED, mixed land-use basin, FOREST, forested basin. Depths indicated represent feet below land surface. 

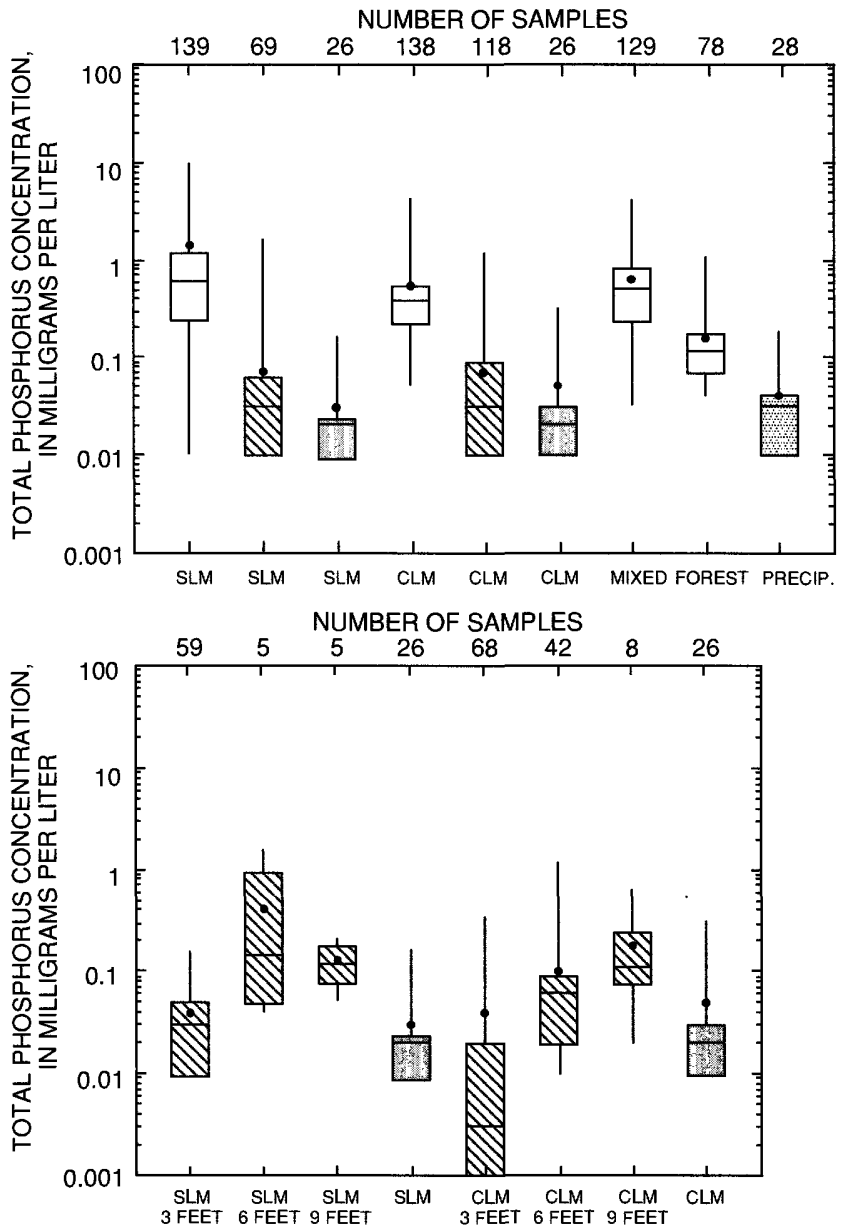

EXPLANATION
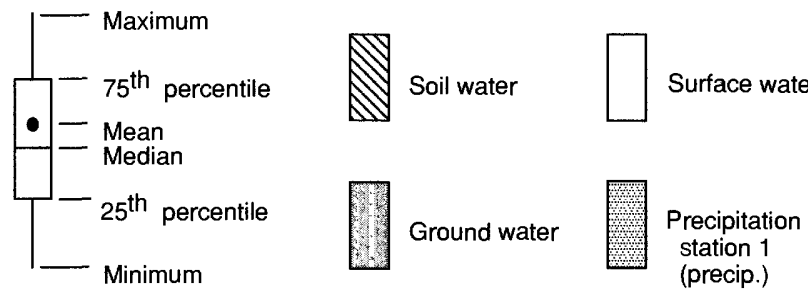

Figure 13. Summary of total phosphorus concentrations in surface water, soil water, and ground water and in precipitation, 1985-90, Guilford County, North Carolina. SLM, standard land-management practices basin; CLM, conservation land-management practices basin; MIXED, mixed land-use basin, FOREST, forested basin. Depths indicated represent feet below land surface.

because there was 19 percent less phosphorus fertilizer applied in the CLM basin than in the SLM basin during the period of study.

Total phosphorus concentrations in soil water in the CLM basin were significantly higher than concentrations in ground water (fig. 13; app. 7). At both row-crop basins, the total phosphorus concentrations in soil water at the 3-foot depth were significantly lower than those at the 6-foot and 9-foot depths. This concentration pattern is similar to that observed for total ammonia and organic nitrogen. As was observed for total ammonia nitrogen and for total amınonia and organic nitrogen, total phosphorus concentrations were lowest just below the root zone (3-foot depth) and in ground water, possibly because of nutrient uptake by plants. In the row-crop basins, total phosphorus concentrations in ground water and soil water were significantly lower than those in surface water (app. 6).

The concentrations of total phosphorus in soil water and ground water in the two row-crop basins indicate that farming can increase concentrations of total phosphorus in soil water. However, no significant differences were observed between total phosphorus concentrations in soil water and ground water in the two basins farmed by using different landmanagement practices.

The median total phosphorus concentration in surface water in all the study basins except the forested basin exceeded $0.1 \mathrm{mg} / \mathrm{L}$, which some investigators consider an indication of potential for algal growth in streams (Mackenthum, 1969). The median concentrations of total phosphorus in soil water, ground water, and precipitation in the four study basins did not exceed $0.1 \mathrm{mg} / \mathrm{L}$.

\section{Potassium Concentrations}

Potassium is an abundant element, commonly occurring in silicate-mineral rocks or in clay, that is essential to plant growth. Potassium is depleted from agricultural soil with crop removal, however, and is a common component of most commercial fertilizers. Potassium concentrations in most natural freshwater streams generally are in the range of a few milligrams per liter or less. Simmons and Heath (1982) reported a range of $0.1-1.8 \mathrm{mg} / \mathrm{L}$ of total potassium in surface water during stormflow and $0.2-1.9 \mathrm{mg} / \mathrm{L}$ of total potassium in base flow from 23 streams in forested and rural basins in the North Carolina Piedmont and Blue Ridge provinces. Caldwell (1992) reported total potassium concentrations of $0.40-2.0 \mathrm{mg} / \mathrm{L}$ for surface water from five stations in forested and rural basins in the Piedmont and Blue Ridge provinces.

Analyses for total potassium concentrations in surface water from the four study basins are listed in table 11. Potassium concentrations in surface water 


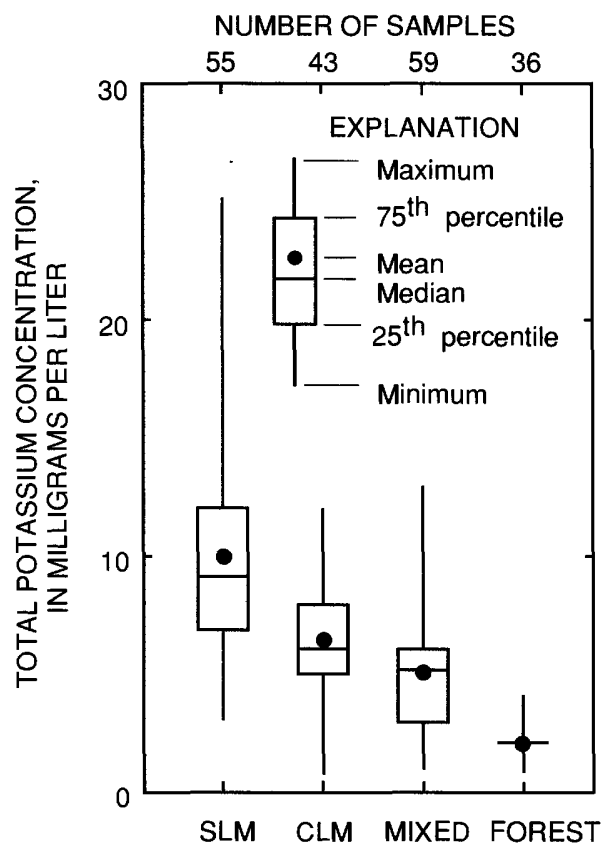

Figure 14. Summary of total potassium concentrations in surface water at the four study basins, 1985-90, Guilford County, North Carolina. SLM, standard land-management practices basin; CLM, conservation land-management practices basin; MIXED, mixed land-use basin, FOREST, forested basin.

from the SLM basin were significantly higher than those in surface water from all the other basins (fig. 14; app. 4), concentrations in the CLM basin were significantly higher than those in the mixed land-use and forested basins, and concentrations in the mixed landuse basin were significantly higher than those in the forested basin. These total potassium concentrations probably reflect potassium associated with clay sediment particles in the surface water.

These results indicate that farming activities can increase concentrations of total potassium in surface water. The total potassium concentrations in the basin farmed by using SLM practices were significantly higher than those in the CLM basin. However, this could be due in part to application of 22 percent less potassium fertilizer in the CLM basin.

\section{Nutrient Yields}

A comparison of nutrient yields in surface-water drainage from the two row-crop basins is a direct means of assessing the relative effects of landmanagement practices on downstream water quality. Comparison of the row-crop basin nutrient yields to those from the mixed land-use and forested basins pro-

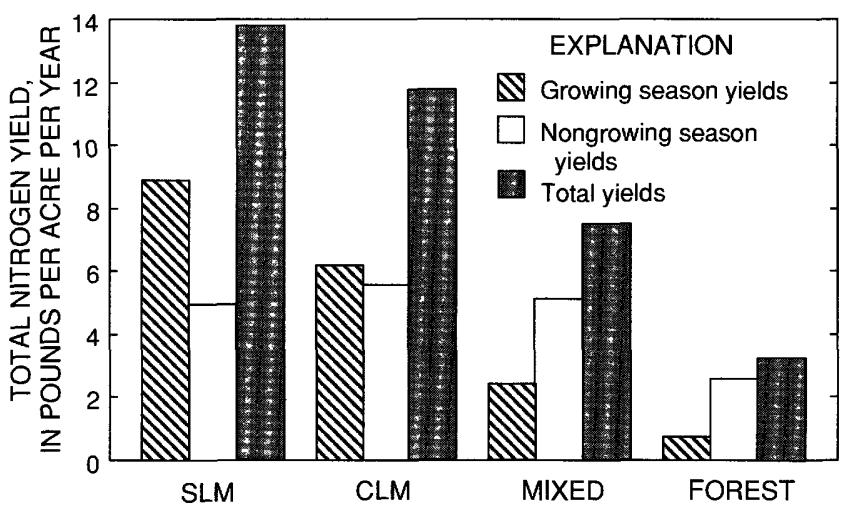

Figure 15. Yields of total nitrogen in surface water at the four study basins, 1985-90, Guilford County, North Carolina. SLM, standard land-management practices basin; CLM, conservation land-management practices basin; MIXED, mixed land-use basin, FOREST, forested basin.

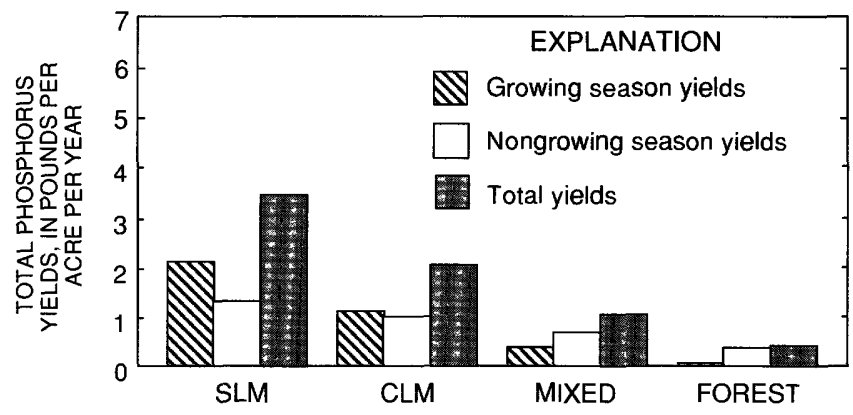

Figure 16. Yields of total phosphorus in surface water at the four study basins, 1985-90, Guilford County, North Carolina. SLM, standard land-management practices basin; CLM, conservation land-management practices basin; MIXED, mixed land-use basin, FOREST, forested basin.

vides a frame of reference for nutrient yields in the row-crop basins.

The general pattern observed for the total nutrient yields is similar to that observed for suspended sediment total yields (fig. 7). The SLM basin had the greatest total nutrient yields, followed by the CLM basin, and then the mixed land-use basin, and then the forested basin (table 10). This pattern was also evident in yields for the growing season (May-September). The total nitrogen yield for the SLM basin was 13.8 pounds per acre per year and was 1.2 times the yield for the CLM basin, 1.9 times the yield for the mixed land-use basin, and 4.2 times the yield for the forested basin (fig. 15). The total phosphorus yield (fig. 16) for the SLM basin was 3.43 pounds per acre per year and was 1.7 times the yield for the CLM basin, 3.2 times the yield for the mixed land-use basin, and 7.8 times the yield for the forested basin. 
Yields of nitrogen during the nongrowing season differed somewhat from those observed for the growing season. The SLM basin yield during the nongrowing season was less than that of the CLM basin. This lower relative yield was probably a reflection of plowing practices for the row-crop basins. In the nongrowing season, the SLM basin was completely disked. This plowing markedly roughened the surface of the field, and substantially reduced surface drainage (fig. 2) and, therefore, transport of nitrogen.

Phosphorus yield in the SLM basin was higher than the yield in the CLM basin during the nongrowing season. This is probably because of sorption of total phosphorus on sediment and higher sediment transport in the SLM basin (fig. 7).

The substantial differences between yields of nutrients in surface water draining the two row-crop basins are evidence that CLM practices can provide a reduction of nutrient yield from a basin. The nutrient yields for the mixed land-use basin and the forested site indicate that further reductions in yields could be expected with less intensive agricultural land uses.

\section{Pesticides}

Concentrations of eight pesticides commonly used in tobacco cultivation were monitored in surface and ground water and soil at the two row-crop basins and in surface water at the mixed and forested basins during the study. The pesticides monitored were acephate, ethoprop, metalaxyl, diphenamid, isopropalin, fenamiphos, flumetralin, and napropamide.

Results of the analyses of water samples for these pesticides are given in appendixes 8 through 18 .

Pesticide applications, as recorded by the farmer in the log of agricultural activities (app. 2A-F), in the row-crop basins during the 1985-90 study period were limited to the growing season and were most numerous during the month of July (fig. 17). Of the eight monitored pesticides, all except ethoprop were reported as used in the row-crop basins during the study, but only acephate, metalaxyl, and flumetralin were used frequently. No record is available of pesticide use for the mixed land-use or forested basins. The frequency of pesticide applications was approximately 15 percent greater in the CLM basin than in the SLM basin (fig. 18). Approximately 14 percent more acephate per acre and 12 percent more diphenamid per acre were applied to the CLM basin than to the SLM basin.
However, these application differences for the monitored pesticides do not necessarily reflect a greater requirement for pesticides in the CLM basin because other pesticides also were used on both basins by the farmers.

\section{Pesticide Concentrations in Surface Water}

Comparison of pesticide concentrations in surface water among the four study basins tests the hypothesis that land-management practices and land use affect pesticide concentrations in surface waters in the basins. The numbers and percentages of samples with detectable concentrations of pesticides in surface water in the four study basins are listed in table 14. The percentages of surface-water samples with detectable concentrations of the monitored pesticides at the four study basins are also shown in figure 19. All of the monitored pesticides were detected in surface water from the SLM basin; all but napropamide were detected in the CLM basin; all but ethoprop, fenamiphos, and isopropalin were detected in the mixed landuse basin; and none of the compounds were detected in the forested basin.

No significant difference between the pesticide concentrations measured in surface water from the SLM basin and the CLM basin (app. 19) was detected. Concentrations of metalaxyl, fenamiphos, and flumetralin in surface water from these two basins were significantly greater than zero, the concentration in the forested basin. Because of the wide range of detection limits reported by the two laboratories for the monitored pesticides, samples with no detectable concentration of a pesticide were assigned a concentration of zero in order to avoid incorrect test significances.

A few differences between pesticide concentrations in surface water in the row-crop basins and in the mixed land-use basin were evident. Concentrations of fenamiphos and flumetralin were significantly higher in surface water in both row-crop basins than in surface water in the mixed land-use basin. However, concentrations of napropamide were significantly higher in the mixed land-use basin than in the rowcrop basins.

Overall, the results did not demonstrate any significant difference between the pesticide concentrations in surface water from the basin farmed by using SLM practices and the basin farmed by using CLM practices. Pesticide concentrations in surface water in the two row-crop basins were not statistically different yet were higher than concentrations in the mixed land- 


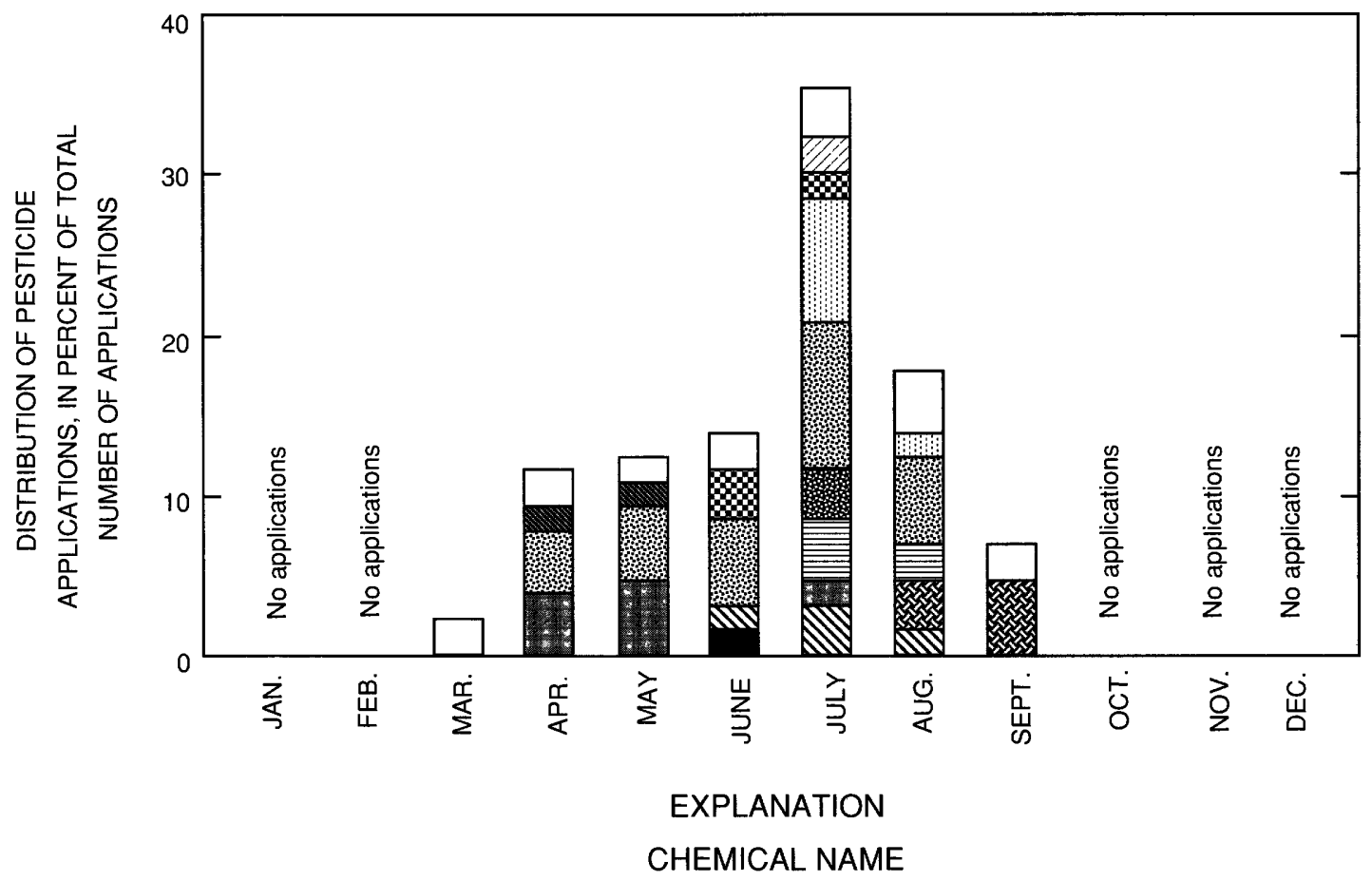

$\begin{array}{lll}\text { Bacephate } & \text { Flumetralin } \\ \text { B8illus thuringiensis } & \text { Carbaryl } & \text { Malathion } \\ \text { Diphenamid } & \text { Maleic hydrazide } \\ \text { Endosulfan } & \text { Other }\end{array}$

Figure 17. Distribution of principal pesticide applications, by month, at the two row-crop basins, 198590, Guilford County, North Carolina.

use and forested basins. The significant differences in pesticide concentrations observed between the rowcrop basins and the mixed land-use basins are probably due to the relative proximity of the sampling sites to the pesticide sources or to differences in application. The sampling site for the mixed land-use basin is separated from any actively farmed area by a stretch of forest in contrast to the intensively farmed row-crop basins; thus, lower pesticide concentrations in surface water in the mixed land-use basin were expected.

\section{Pesticide Concentrations in Ground Water and Soil in the Row-Crop Basins}

Pesticide concentrations in ground water and soil are compared between the two row-crop basins and with concentrations in surface water in this section. A summary of the number of soil and groundwater samples with detectable concentrations of monitored pesticides is listed in table 15 and shown in figure 20. The probability levels for the Wilcoxon ranked sum test comparisons between ranked sums of pesticide concentrations measured in surface water and ground water; between ranked sums of concentrations in surface water and soil at 3-, 6-, and 9-inch depths; and between ranked sums of concentrations in ground water for the two row-crop basins are given in appendix 19. Probability levels for comparisons between pesticide concentrations measured in surface water and soil at all depths for the row-crop basins are given in appendix 20. Probability levels for comparisons between pesticide concentrations measured in soil at 3-, 6-, and 9-inch depths are given in appendix 21.

All of the pesticides analyzed were detected in soil at both row-crop basins. Concentrations of isopropalin and flumetralin in soil samples were significantly greater in the SLM basin than in the CLM basin. 
Table 14. Summary of the number of surface-water samples with detectable concentrations of monitored pesticides in the four study basins, 1985-90, Guilford County, North Carolina

\begin{tabular}{|c|c|c|c|c|c|c|c|c|}
\hline \multirow{2}{*}{$\begin{array}{l}\text { Basin and sample type } \\
\text { Standard land-management practices basin }\end{array}$} & \multirow[t]{2}{*}{ Acephate } & \multirow[t]{2}{*}{ Ethoprop } & \multirow[t]{2}{*}{ Metalaxyl } & \multicolumn{5}{|c|}{ Diphenamid Isopropalin Fenamiphos Flumetralin Napropamide } \\
\hline & & & & & & & & \\
\hline 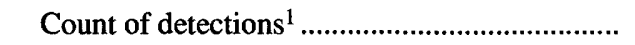 & 2 & 4 & 13 & 13 & 1 & 9 & 17 & 1 \\
\hline 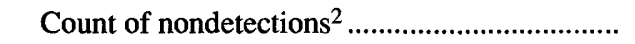 & 20 & 18 & 9 & 9 & 21 & 13 & 5 & 21 \\
\hline Percent with detectable concentration................ & 9 & 18 & 59 & 59 & 5 & 41 & 77 & 5 \\
\hline \multicolumn{9}{|l|}{ Conservation land-management practices basin } \\
\hline 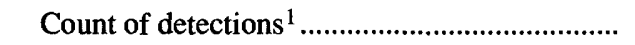 & 5 & 4 & 11 & 13 & 1 & 10 & 15 & 0 \\
\hline 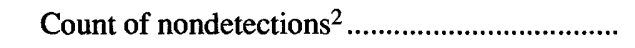 & 17 & 18 & 11 & 9 & 21 & 12 & 6 & 22 \\
\hline Percent with detectable concentration................... & 23 & 18 & 50 & 59 & 5 & 45 & 71 & 0 \\
\hline \multicolumn{9}{|l|}{ Mixed land-use basin } \\
\hline Count of detections ${ }^{1}$ & 1 & 0 & 7 & 6 & 0 & 0 & 5 & 3 \\
\hline 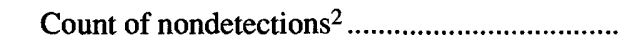 & 14 & 15 & 8 & 9 & 15 & 15 & 9 & 10 \\
\hline Percent with detectable concentration............... & 7 & 0 & 47 & 40 & 0 & 0 & 36 & 33 \\
\hline \multicolumn{9}{|l|}{ Forested basin } \\
\hline Count of detections ${ }^{1}$....... & 0 & 0 & 0 & 0 & 0 & 0 & 0 & 0 \\
\hline 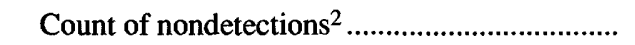 & 8 & 8 & 8 & 8 & 8 & 8 & 8 & 8 \\
\hline Percent with detectable concentration............... & 0 & 0 & 0 & 0 & 0 & 0 & 0 & 0 \\
\hline
\end{tabular}

${ }^{1}$ Number of samples with detectable concentration.

2 Number of samples with no detectable concentration.

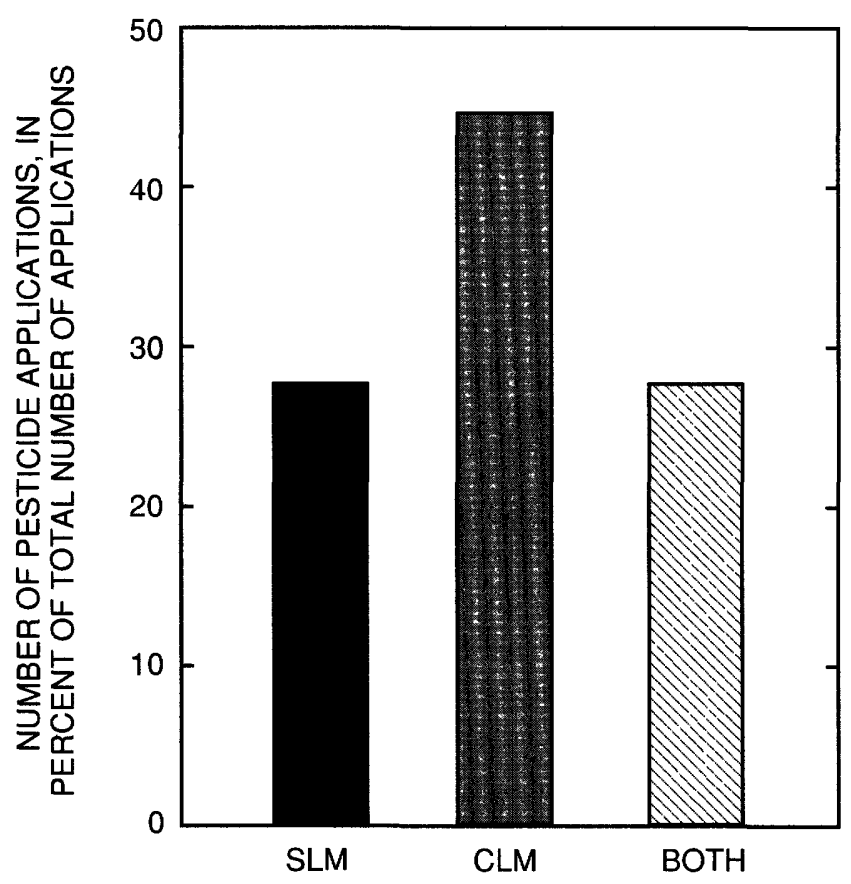

Figure 18. Percentage of pesticide applications at the standard land-management (SLM) practices basin, at the conservation land-management (CLM) practices basin, and at both (BOTH) basins, 1985-90, Guilford County, North Carolina.

Concentrations of ethoprop were significantly greater in soil samples than in surface-water samples for both row-crop basins. In the SLM basin, concen- trations of metalaxyl in soil samples collected at a depth of 6 inches, isopropalin in soil samples collected at depths of 3 and 6 inches, and flumetralin in soil samples collected at depths of 3,6, and 9 inches were greater than concentrations in surface water from the basin. Concentrations of fenamiphos were significantly greater in surface-water samples from the SLM basin than in soil samples from the basin.

These results indicate a greater capacity to retain pesticide concentrations in the soil of the SLM basin than in the soil of the CLM basin in spite of the high sediment transport from the SLM basin relative to the CLM basin. This greater retention capacity could be due to soil-type differences between the basins. There could be a greater percentage of clay or some other soil with a greater sorptive capacity in the SLM basin than in the CLM basin. Another possible explanation is that the soil conditions are similar between the basins, but the conditions for transformation of the pesticides are more favorable in the CLM basin. CLM practices affect physical soil conditions, such as soil moisture, which can affect pesticide transformation.

Diphenamid, fenamiphos, and flumetralin were detected in ground water for both row-crop basins; and metalaxyl and isopropalin were detected in ground water in the SLM basin. Concentrations of metalaxyl and flumetralin in surface water were significantly higher than concentrations in ground water at both row-crop basins. 


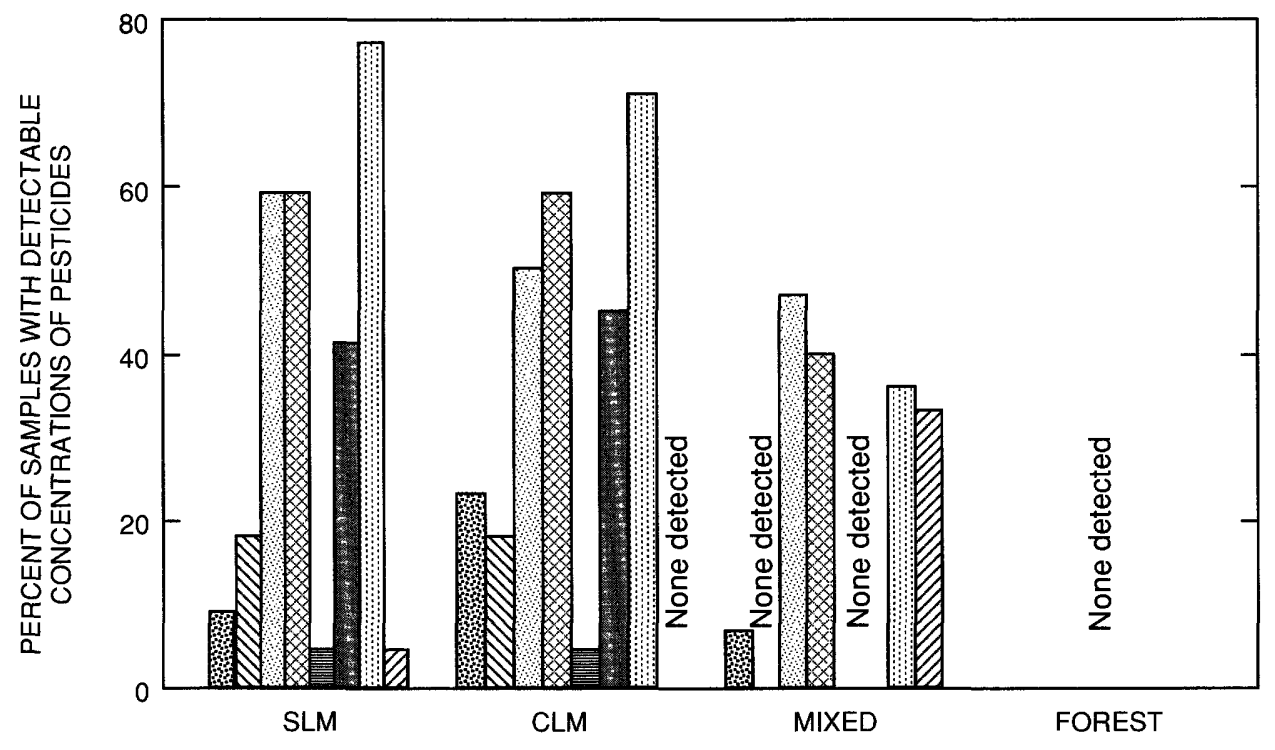

EXPLANATION

$\begin{array}{ll}\text { Acephate } & \text { Flumetralin } \\ \text { Diphenamid } & \text { Isopropalin } \\ \text { Ethoprop } & \text { Metalaxyl } \\ \text { Fenamiphos } & \text { Napropamide }\end{array}$

Figure 19. Percentage of surface-water samples with detectable concentrations of monitored pesticides in the four study basins, 1985-90, Guilford County, North Carolina. SLM, standard land-management practices basin; CLM, conservation land-management practices basin; MIXED, mixed land-use basin, FOREST, forested basin.

Results of pesticide analyses did not indicate substantial differences between concentrations of most pesticides in surface water and ground water in the CLM and the SLM basins. However, two pesticides were detected in higher concentrations in soils in the SLM basin than in soils in the CLM basin, and in the SLM basin several pesticides were detected in higher concentrations in soils than in surface water. Data are insufficient to determine if this result is an effect of land-management practices.

\section{SUMMARY}

The effects of different land uses and agricultural land-management practices on surface-water and ground-water quality were studied in four basins in the Piedmont of North Carolina. The study involved monitoring chemicals applied to the land through farming practices and major plant nutrients in precipitation during 1985-90. The quantity and quality of surface water in drainages from each basin, concentrations of chemical constituents percolating through the clay soils in the unsaturated zone in the two row-crop basins, and constituents reaching the ground water beneath the row-crop basins were also monitored. Farmers cooperating in the study kept detailed records of their farming activities, such as plowing and the application of chemicals to their fields.

Four areas, consisting of two row-crop basins, a mixed land-use basin, and a forested basin, were selected for study. The row-crop basins are adjacent; one was farmed by using CLM practices ( 7.4 acres) and the other was farmed by using SLM practices (4.8 acres).

Comparisons of various water and soil quality characteristics among the basins were made on the basis of the nonparametric Kruskall-Wallis analysis of variance to establish whether a difference existed among multiple distributions of concentrations or yields of a given chemical constituent. When there was a significant difference, then a Wilcoxon ranked 
Table 15. Summary of the number of soil and ground-water samples with detectable concentrations of monitored pesticides in the two row-crop basins, 1985-90, Guilford County, North Carolina

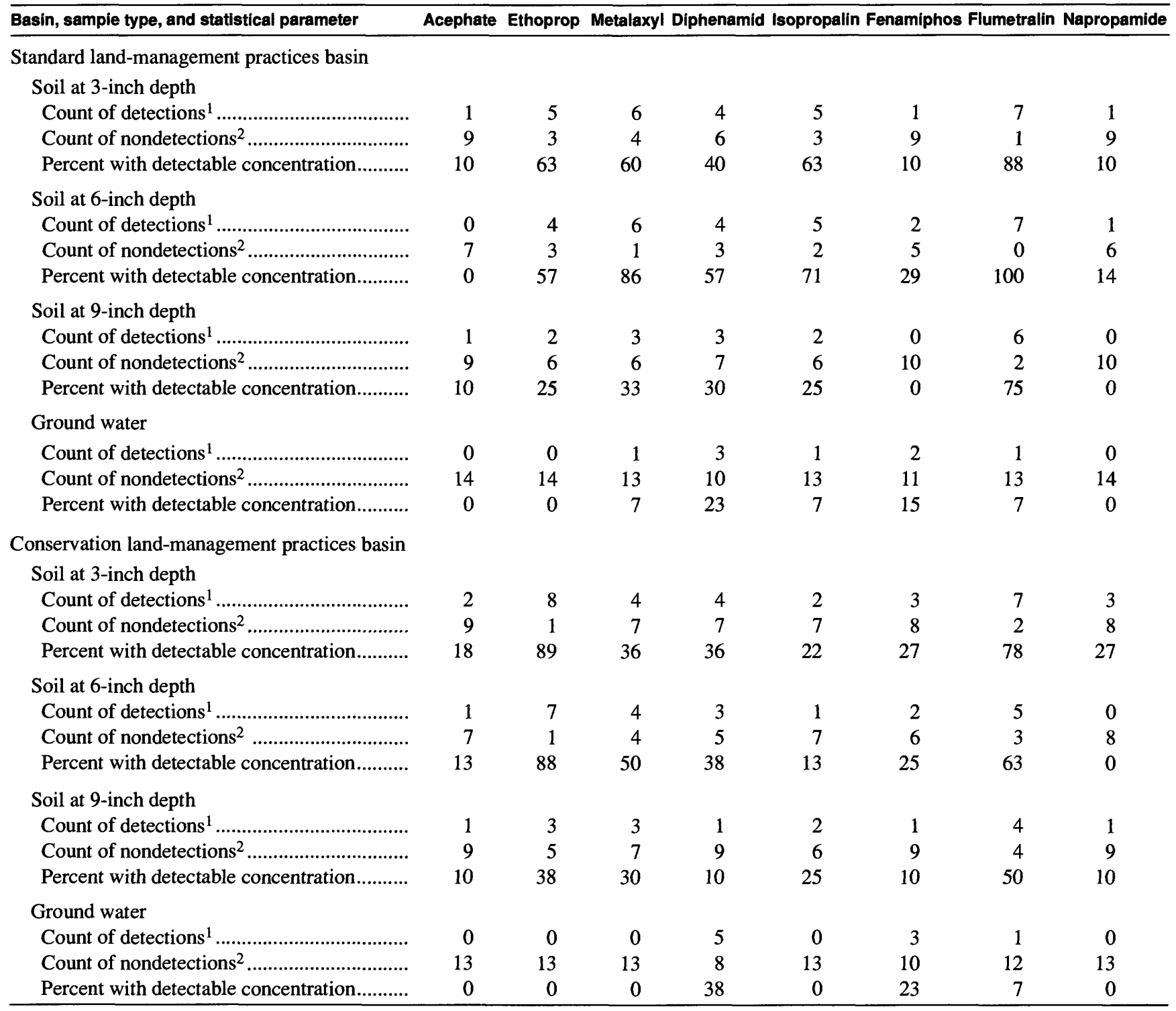

${ }^{1}$ Number of samples with detectable concentration.

${ }^{2}$ Number of samples with no detectable concentration.

sum test was used to determine which distributions were different. For simplicity in terminology, Wilcoxon tests between distributions are referred to as comparisons between basin constituent concentrations.

Land-management practices in the two adjacent row-crop basins differed substantially. In the CLM practices basin, farming practices included conservation cropping systems, strip cropping, conservation tillage, contour plowing, field borders, grassed waterways, and terraces or diversions. In the SLM practices basin, farming practices included continuous cropping, straight-row plowing without regard to land

topography and slope, and poorly maintained waterways. During the study, the row-crop basins were planted in tobacco and grain crops, a typical North Carolina Piedmont agricultural land use. In the region, the greatest acreages of highly erodible soils are planted in corn and tobacco.

Two other sites provided a frame of reference for the water-quality comparisons between the two row-crop basins. A mixed land-use basin ( 665 acres) was monitored to provide a comparison of surfacewater quality at a larger scale basin to water quality at . the row-crop fields. Background hydrologic and chemical-quality conditions were monitored in the 

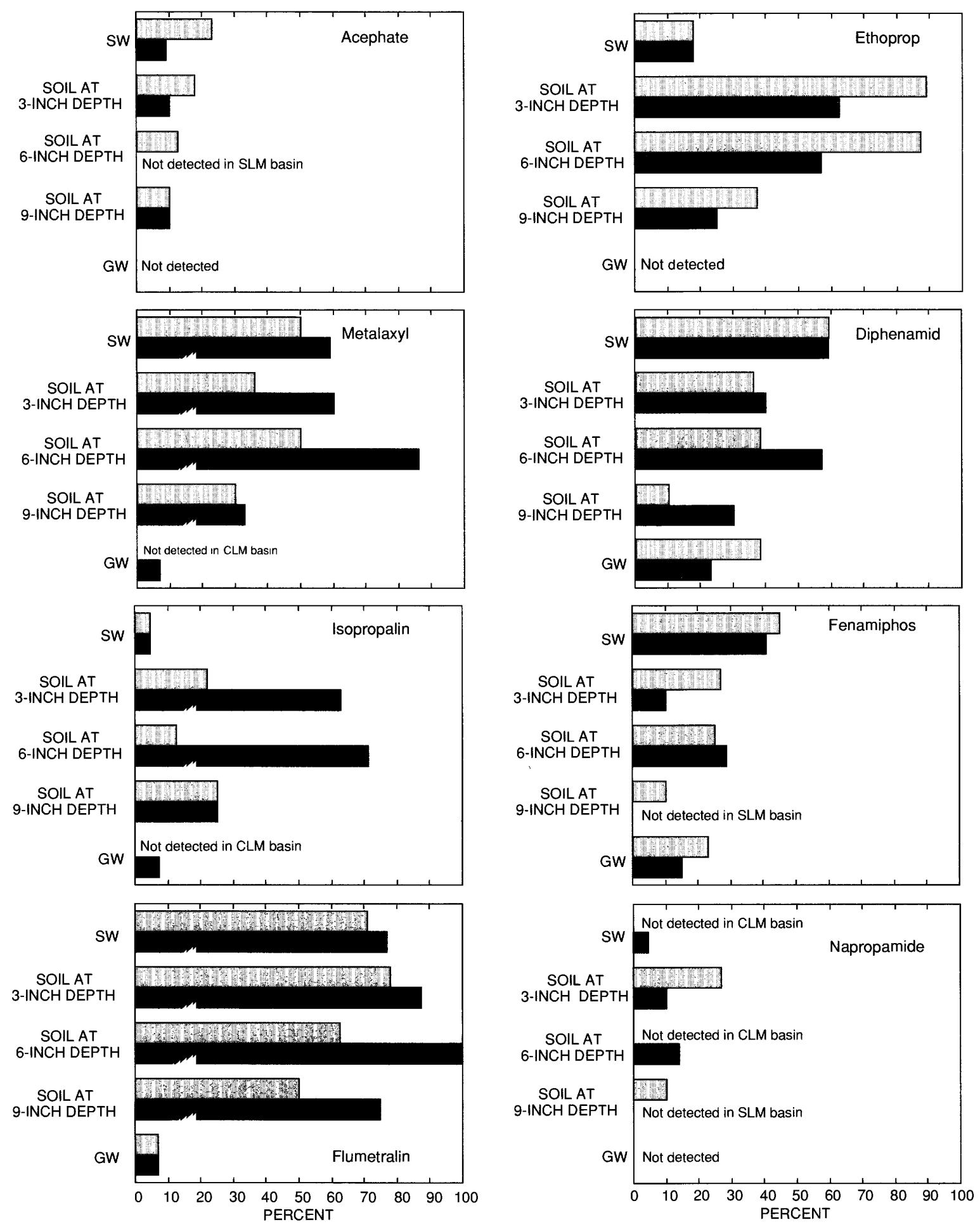

EXPLANATION

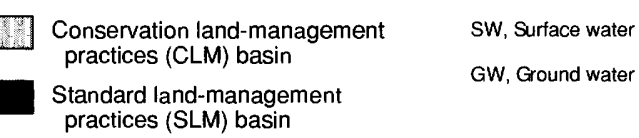

Figure 20. Percentage of surface-water, soil, and ground-water samples with detectable concentrations of the pesticides acephate, ethoprop, metalaxyl, diphenamid, isopropalin, fenamiphos, flumetralin, and napropamide in the two row-crop basins, 1985-90, Guilford County, North Carolina. 
forested basin ( 44 acres). The four study basins were within a 4-mile radius, and the effects of atmospheric deposition, which was monitored at one of the rowcrop basins, were assumed to be equal in each of the four areas.

Streamflow and concentrations and yields of sediment, nutrients (nitrogen, phosphorus, and potassium compounds), and selected pesticides in surface water were monitored for the study basins. Nitrogen, phosphorus, and potassium compounds and selected pesticides were also monitored in soil water and ground water in the row-crop basins.

Effects of differing land-management practices and land use on streamflow were evaluated by comparing streamflow per unit area among the four study basins. The SLM practices basin had the highest streamflow per unit area, or 14.8 inches per year. This was 18 percent greater than the streamflow per unit area in the CLM practices basin of 12.5 inches per year. The comparisons demonstrate a distinct, and statistically significant, reduction of streamflow by CLM practices, evident particularly during the growing season. The streamflow per unit area was similar for the CLM basin, the mixed land-use basin, and the forested basin.

Distinct differences in $\mathrm{pH}$ were evident among the study basins. Surface water in the row crop basins was more acidic than in the mixed land-use and forested basins, and the SLM practices basin surface water was significantly more acidic than that of the CLM practices basin. These basin differences are probably due to increased buffering with increasing lengths of flow paths for water as a result of land use, land management, and basin size. Additionally, nitrification of ammonia from fertilizer added to agricultural areas has an acidifying effect on soils. Inexplicably, the ground-water $\mathrm{pH}$ values reverse the pattern seen in surface water for the row-crop basins. Precipitation was more acidic than surface water or ground water from all of the basins.

Specific conductance in surface water was higher in the SLM practices basin than in the CLM practices basin. Specific conductance values for the CLM basin were similar to those observed for the forested basin.

Suspended-sediment concentrations and yields for surface waters in the four basins were highest in the SLM practices basin and lowest in the forested basin. The median sediment concentration for the SLM practices basin was 3.4 times that of the CLM practices basin, 8.2 times that of the mixed land-use site, and 38.4 times that of the forested basin. The suspended sediment in surface water from the SLM practices basin included larger particle sizes than those observed in surface water from the CLM practices basin, reflecting higher energy erosion in the SLM practices basin.

Sediment yields for the SLM practices basin were considerably higher than those observed for the other basins. The total sediment yield for the SLM practices basin was 2.3 times that observed for the CLM basin, 14.1 times that observed for the mixed land-use basin, and 19.5 times the yield observed for the forested basin.

Fertilizer was applied to the two row-crop basins throughout the growing season but was applied most frequently during the month of May. The number of fertilizer applications to the CLM practices basin was 5 percent greater than that for the SLM practices basin.

Concentrations of nitrogen and phosphorus compounds and potassium in surface water from the row-crop and mixed land-use basins were higher than those measured in the forested basin and in precipitation. The SLM practices basin had the highest nitrite plus nitrate, total nitrogen, total phosphorus (along with the mixed land-use basin), and potassium concentrations in surface water of all the basins. The CLM practices basin had the highest ammonia nitrogen and dissolved orthophosphorus concentrations in surface water of all the basins.

Concentrations of nitrogen and phosphorus compounds and potassium in soil water and ground water were lower than concentrations in surface water in the two row-crop basins. Ammonia nitrogen, total nitrogen, dissolved orthophosphorus, and total phosphorus concentrations in soil water increased slightly with depth through the soil profile in the row-crop basins, but this increase was not statistically significant. The lowest concentrations of ammonia nitrogen, ammonia and organic nitrogen, total nitrogen, dissolved orthophosphorus, and total phosphorus in soil water and ground water in the row-crop basins were generally detected just below the root zone (3-foot depth) in soil water and in ground water.

Nutrient concentrations occurred at levels sufficient to support nuisance growth of algae in streams. The median total nitrogen concentration exceeded $1.0 \mathrm{mg} / \mathrm{L}$ in surface water and $0.30 \mathrm{mg} / \mathrm{L}$ in precipitation. A total nitrogen concentration of $0.30 \mathrm{mg} / \mathrm{L}$ is 
considered sufficient to support nuisance growth of algae. Median total phosphorus concentrations in surface water exceeded $0.1 \mathrm{mg} / \mathrm{L}$, a level reported to indicate the potential for algal growth, in all but the forested basin. However, median total phosphorus concentrations in soil water, ground water, and precipitation were below the $0.1 \mathrm{mg} / \mathrm{L}$ level.

The general pattern of differences between basins for total nutrient yields was similar to that observed for suspended sediment yields. The total nitrogen yield for the SLM practices basin was 1.2 times the yield for the CLM practices basin, 1.9 times the yield for the mixed land-use basin, and 4.2 times the yield for the forested basin. The total phosphorus yield for the SLM practices basin was 1.7 times the yield for the CLM practices basin, 3.3 times the yield for the mixed land-use basin, and 7.8 times the yield for the forested basin.

Pesticides were periodically applied to the two row-crop basins throughout the April-September growing season but were applied most frequently during the month of July. The number of pesticide applications during this study was approximately 15 percent greater in the CLM practices basin than in the SLM practices basin.

No significant differences in pesticide concentrations in surface water were identified between those measured in the SLM practices basin and those measured in the CLM practices basin. Significantly higher pesticide concentrations were observed at the rowcrop basins compared with those observed at the mixed land-use basin, probably because sampling sites for the row-crop basins were closer to the pesticide sources. No pesticides were detected in the forested basin.

Metalaxyl, isopropalin, fenamiphos, and flumetralin were detected in surface water, soil, and ground water at the row-crop basins. Acephate, ethoprop, and napropamide were detected in surface water and soil at the row-crop basins but not in ground water. Concentrations of ethoprop, isopropalin, and flumetralin in soil were significantly higher than concentrations in surface water at both row-crop basins. Concentrations of fenamiphos in soil in the SLM practices basin were lower than concentrations in surface water from that basin.

Comparisons of pesticide concentrations in soil and surface water at the row-crop basins indicated some differences between the basins. Concentrations of isopropalin and flumetralin in soils were higher in the SLM practices basin than in the CLM practices basin, but it is not known if the differences are related to land-management practices in the two basins.

Overall, agricultural land-management practices in the four basins had distinct effects on sediment and nutrient concentrations in surface water, but no conclusive effects on ground-water quality and pesticide concentrations in surface and ground water were observed. SLM practices resulted in higher concentrations and yields of sediments and nutrients in surface water compared to CLM practices. The mixed landuse basin generally had lower concentrations of suspended sediment, nutrients, and pesticides than those in the row-crop basins, probably because of forested areas and 13 small farm ponds in the basin, which tended to trap sediment, nutrients, and pesticides. Surface water in the forested basin generally had the lowest concentrations of sediment and nutrients, and no pesticides were detected in surface water from this basin.

\section{REFERENCES CITED}

Anderson, J.R., Hardy, E.E., Roach, J.T., and Witmer, R.E., 1976, A land use and land cover classification system for use with remote sensor data: U.S. Geological Survey Professional Paper 964, 28 p.

Atkins, J.B., 1984, Agricultural nonpoint source control case studies in North Carolina-IV. Wake County demonstration farm: Biological and Agricultural Engineering Department, North Carolina State University, $119 \mathrm{p}$.

Brady, N.C., 1974, The nature and properties of soils: New York, Macmillan, $639 \mathrm{p}$.

Caldwell, W.S., 1992, Selected water-quality and biological characteristics of streams in some forested basins of North Carolina, 1985-88: U.S. Geological Survey Water-Resources Investigations Report 92-4129, $114 \mathrm{p}$.

Calvo-Alvarado, J.C., 1990, Predicting mean annual runoff and suspended sediment yield in rural watersheds in North Carolina: Department of Forestry, North Carolina State University, Ph.D. dissertation, 209 p.

Cohn, T., Delong, L.L., Gilroy, E.J., Hirsch, R.M., and Wells, D.K., 1989, Estimating constituent loads: Water Resources Research, v. 25, no. 5, p. 937-942.

Daniel, C.C., III, and Sharpless, N.B., 1983, Ground-water supply potential and procedures for well-site selection in the upper Cape Fear River basin, North Carolina: North Carolina Department of Natural Resources and Community Development, $73 \mathrm{p}$. 
Daniels, R.B., Kleiss, H.J., Boul, S.W., Byrd, H.J., and Phillips, J.A., 1984, Soil systems in North Carolina: North Carolina Agricultural Research Service, North Carolina State University, Bulletin 467, 77 p.

Donigian, A.S., Jr., and Carsel, R.F., 1987, Modeling the impact of conservation tillage practices on pesticide concentrations in ground and surface waters: Environmental Toxicology and Chemistry, v. 6, p. 241.

Eder, B.K., Davis, J.M., and Robinson, P.J., 1983, Variations in monthly precipitation over North Carolina: The University of North Carolina Water Resources Research Institute, report no. $185,50 \mathrm{p}$.

Fenneman, N.M., 1938, Physiography of eastern United States: New York, McGraw-Hill, 714 p.

Fishman, M. J., and Friedman, L.C., eds., 1985, Methods for determination of inorganic substances in water and fluvial sediments: U. S. Geological Survey Techniques of Water-Resources Investigations, book 5, chap. A1, $545 \mathrm{p}$.

Gilroy, E.J., Hirsch, R.M., and Cohn, T., 1990, Mean square error of regression-based constituent transport estimates: Water Resources Research, v. 36, no. 9, p. 2069-2077.

Gregory, K.J., and Walling, D.E., 1973, Drainage basin form and process: New York, John Wiley and Sons, $458 \mathrm{p}$.

Harned, D.A., 1989, The hydrogeologic framework and a reconnaissance of ground-water quality in the Piedmont province of North Carolina, with a design for future study: U.S. Geological Survey Water-Resources Investigation Report 88-4130, 55 p.

Harper, W.C., 1987, A resource agency's perspective on nonpoint source management, a symposium monitoring, modeling, and mediating water quality: Syracuse, N.Y., American Water Resources Association, p. $641-652$.

Helsel, D.R., and Hirsch, R.M, 1992, Statistical methods in water resources: New York, Elsevier, 522 p.

Hill, C.L., 1989, Hydrologic and chemical-quality data from four rural basins in Guilford County, North Carolina, 1985-88: U.S. Geological Survey Open-File Report 89-578, 105 p.

-1991, Effects of land-management practices on sediment yield in northeastern Guilford County, North Carolina: U.S. Geological Survey Water Resources Investigations Report 90-4127, 40 p.

Hirsch, R.M., Slack, J.R., and Smith, R.A., 1982, Techniques of trend analysis for monthly water-quality data: Water Resources Research, v. 18, no. 1, p. 107-121.

Lanier, A.L., and Hunt, J.N., 1986, Energy efficient/environmental quality demonstration farms project, final report, November 11, 1983, through September 30, 1986: Biological and Agricultural Engineering Department, North Carolina State University, 111 p.
LeGrand, H.E., 1967, Ground water of the Piedmont and Blue Ridge provinces in the southeastern States: U.S. Geological Survey Circular 538, 11 p.

Mackenthum, K.M., 1969, The practice of water pollution biology: Washington, D.C., Federal Water Pollution Control Administration, $281 \mathrm{p}$.

National Oceanic and Atmospheric Administration, 1990, Hourly precipitation data-Annual summary, North Carolina: Asheville, N.C., National Climatic Center, v. 40 , no. 13,8 p.

National Technical Advisory Committee, 1968, Waterquality criteria, a report of the National Technical Advisory Committee to the Secretary of the Interior: Washington, D.C., U.S. Government Printing Office, 234 p.

National Water Quality Evaluation Project, 1989, National Water Quality Evaluation Project 1988 annual reportStatus of agricultural nonpoint source projects: U.S. Environmental Protection Agency, EPA 506/9-89/002, $169 \mathrm{p}$.

North Carolina Department of Environment, Health, and Natural Resources, 1989, North Carolina nonpoint source management program: Division of Environmental Management, Water Quality Section, Water Quality Technical Report 89-02, p. 35-41.

North Carolina Environmental Management Commission, 1979, Classification and water quality standards applicable to surface waters of North Carolina: North Carolina Environmental Management Commission, Administrative Code, title 15, p. 23-30.

Sakamoto, M., 1966, Primary production by phytoplankton community in some Japanese lakes and its dependence on lake depth: Archiz Suer Hydrobiologie, v. 62, p. 1-28.

Sauer, T.J., and Daniel, T.C., 1987, Effect of tillage system on runoff losses of surface-applied pesticides: Soil Sciences Society of America Journal, v. 51, p. 410.

Sawyer, C.N., 1947, Fertilization of lakes by agricultural and urban drainage, in New England Water Works Association Journal, v. 61, no. 2, p. 109-127.

Scaling, W., 1988, Implementing conservation compliance and sodbuster-A federal view: Journal of Soil and Water Conservation, v. 43, no. 1, p. 22-24.

Simmons, C.E., 1988, Sediment characteristics of North Carolina streams, 1970-79: U.S. Geological Survey Open-File Report 87-701, 130 p.

Simmons, C.E., and Heath, R.C., 1982, Water-quality characteristics of streams in forested and rural areas of North Carolina: U.S. Geological Survey Water-Supply Paper 2185-B, 33 p.

Smith, J.A., Witkowski, P.J., and Fusillo, T.V., 1988, Manmade organic compounds in the surface waters of the United States-A review of current understanding: U.S. Geological Survey Circular 1007, 92 p. 
Spooner, Jean, 1990, Meteorologic and hydrologic effects on water quality-Part I. Importance in monitoring nonpoint source control programs, in National Water Quality Evaluation Project Notes: North Carolina Agricultural Extension Service, North Carolina State University, p. 3-5.

Spooner, Jean, Maas, R.P., Dressing, S.A., Smolen, M.D., and Humenik, F.J., 1985, Appropriate designs for documenting water quality improvements from agricultural nonpoint source control programs, in Perspectives on nonpoint source pollution; Proceedings of a National Conference, Kansas City, Mo., May 19-22, 1985: U.S. Environmental Protection Agency, EPA 44015-85-001, p. 30-34.

Spooner, Jean, Wyatt, L., Berryhill, W.S., Lanier, A.L., Brichford, S.L., Smolen, M.D., Coffey, S.W., and Bennet, T.B., 1989, Fate and effects of pollutants-

Nonpoint sources: Journal of the Water Pollution Control Federation, v. 61, no. 6, p. 911-924.

U.S. Department of Agriculture, 1977, Soil survey of Guilford County: Washington, D.C., Soil Conservation Service, $77 \mathrm{p}$.

1985, Haw River erosion study, North Carolina: Soil Conservation Service and Forest Service, 68 p.

U.S. Environmental Protection Agency, 1985, Final report on the Federal/State/local nonpoint source task force and recommended national nonpoint source policy: Washington, D.C., U.S. Environmental Protection Agency, $38 \mathrm{p}$.

1986, Quality criteria for water: Washington, D.C., U.S. Government Printing Office, U.S. Environmental Protection Agency, EPA 445-86-001, 256 p.

Vollenweider, R.A., 1971, Scientific fundamentals of the eutrophication of lakes and flowing waters, with particular reference to nitrogen and phosphorus as factors in eutrophication: Paris, Organization for Economic Cooperation and Development, $193 \mathrm{p}$.

Weiss, C.M., Francisco, D.E., and Lenat, D.R., 1973, Preimpoundment studies-Falls project-Water-quality characteristics, in U.S. Army Corps of Engineers draft environmental statement, Falls Lake, Neuse River basin, North Carolina, appendix I: Wilmington, N.C., U.S. Army Corps of Engineers, 199 p.

Wentworth, C.K., 1922, A scale of grade and class terms for clastic sediments: Journal of Geology, v. 30, p. 377-392.

Wischmeier, W.H., and Smith, D.D., 1978, Predicting rainfall erosion losses-A guide to conservation planning: U.S. Department of Agriculture, Soil Conservation Service Handbook 537, 58 p. 
APPENDIXES 1-21 


\section{APPENDIX 1. Log of Farming Activities at the Row-Crop Basins, 1984-90, Guilford County, North Carolina}

[CLM, conservation land-management practices; SLM, standard land-management practices; Do., ditto. Source: John Andrews, Guilford County Soil and Water Conservation District, written commun., 1991]

\begin{tabular}{|c|c|}
\hline Date & Activity \\
\hline $10-01-84$ & Cut stalks and disked field. \\
\hline $04-22-85$ & Began planting tobacco. \\
\hline $05-01-85$ & $\begin{array}{l}100 \text { percent of tobacco planted in CLM and SLM } \\
\text { field. }\end{array}$ \\
\hline $05-11-85$ & $\begin{array}{l}\text { Replanted some tobacco in SLM field; also irrigated } \\
\text { parts of SLM field with } 3 / 4 \text { inch of water. }\end{array}$ \\
\hline $05-12-85$ & Do. \\
\hline $05-13-85$ & Do. \\
\hline $05-25-85$ & Tobacco in both fields cultivated. \\
\hline $06-04-85$ & Do. \\
\hline $06-10-85$ & Cultivated tobacco in CLM field. \\
\hline $08-02-85$ & Harvested tobacco in CLM field. \\
\hline $09-17-85$ & $\begin{array}{l}\text { Harvest complete in CLM field; about } 20 \text { percent } \\
\text { complete in SLM field. }\end{array}$ \\
\hline $09-24-85$ & Tobacco harvest complete. \\
\hline $09-27-85$ & $\begin{array}{l}\text { Stalks cut and fields disked-both fields, including } \\
\text { old strips. }\end{array}$ \\
\hline $10-11-85$ & $\begin{array}{l}\text { Regraded waterways and laid out strip cropping in } \\
\text { CLM field. }\end{array}$ \\
\hline $10-15-85$ & $\begin{array}{l}\text { Waterways and strips in CLM field seeded with fes- } \\
\text { cue and wheat. Waterway mulched with straw. } \\
\text { Heavy thunderstorm in late afternoon washed out } \\
6 \text {-foot-wide area through center of waterway at } \\
\text { lower end. Farmer estimated } 2 \text { inches of rain. }\end{array}$ \\
\hline $10-18-85$ & $\begin{array}{l}\text { Reworked washed area of waterway; reseeded, } \\
\text { mulched, and put down } 1,050 \text { feet of } 12 \text {-foot-wide } \\
\text { netting. }\end{array}$ \\
\hline $10-25-85$ & Small grain and fescue germinated in both waterways \\
\hline
\end{tabular}
and strips.

11-14-85 Approximately one-half of SLM field has been turnplowed.

12-03-85 Crop area of CLM field turn-plowed and all of SLM field turn-plowed. Small grain broadcast and slight growth in both fields.

03-28-86 Sodding and seeding eroded areas in waterways in CLM field. Both fields disked and leveled; ready for bedding up rows.

05-05-86 Tobacco planted in part of CLM field and part of SLM field.

05-06-86 100 percent of tobacco planted in CLM field; 85 percent planted in SLM field.

05-09-86 100 percent of tobacco planted in SLM field. Some plants dead because of dry conditions.

06-02-86 Cultivating tobacco.

06-16-86 Small grain harvested in strips. Stubble left is 6 to 12 inches high.

06-19-86 Irrigated 56 rows in SLM field on upper side; estimated amount: $1 / 2$ to 1 inch.

07-11-86 Irrigated CLM field: $1 / 2$ to 1 inch.

07-15-86 Irrigated SLM field: $1 / 2$ to 1 inch.

07-17-86 Irrigated CLM field and upper half of SLM field: $1 / 2$ to 1 inch.

07-22-86 Irrigated lower half of SLM field: $1 / 2$ to $1 \mathrm{inch}$.

\begin{tabular}{cl}
\hline Date & \multicolumn{1}{c}{ Activity } \\
\hline $08-22-86$ & Both fields harvested. \\
$10-08-86$ & All tobacco has been harvested. \\
$10-20-86$ & Tobacco strips have been disked. Will mow grass this
\end{tabular}
week.

04-10-87 Disked both fields.

04-23-87 Heavy rains last week caused severe erosion in SLM field, filling up previously excavated area. No plowing done or chemicals applied.

04-30-87 Both fields worked with disk.

05-07-87 Bedded up rows. Will begin planting in CLM field tomorrow.

05-19-87 All of SLM field planted.

05-25-87 All tobacco planted in both fields.

06-01-87 Cultivating both fields.

06-23-87 Cultivating tobacco in both fields.

06-30-87 Irrigated SLM field.

07-11-87 Irrigated CLM field.

07-13-87 Do.

07-29-87 Irrigated SLM field.

08-04-87 Irrigated part of SLM field.

08-06-87 Do.

08-08-87 Irrigated SLM field.

08-11-87 Irrigated CLM field.

08-12-87 Irrigated part of CLM field; began harvesting.

08-20-87 Both fields harvested once to date.

08-27-87 Harvesting in both fields.

10-06-87 All of tobacco harvested in lower strips of CLM field and part of SLM field.

10-14-87 All tobacco harvested.

10-20-87 Tobacco stalks cut in with disk in both fields.

10-26-87 Reconstructed waterway in SLM field.

$11-02-87$ Waterway in SLM field seeded and mulched.

11-05-87 Netting installed to hold seed down in waterway in SLM field.

11-06-87 Strips planted with small grain and fescue in CLM field.

11-13-87 Old fescue plowed under in CLM field.

11-16-87 Replanting small grain in strips in CLM field. Very little germination of seed in waterway in SLM field.

12-03-87 Small grain is 1 to 2 inches high in strips in CLM field; little fescue evident. Waterway in CLM field has good stand of small grains and fescue.

02-29-88 Old fescue disked in CLM field. SLM field disked.

03-01-88 No fescue germination evident in strips in CLM field.

03-07-88 Fescue replanted in strips in CLM field. Tobacco rows bedded up in both fields.

04-22-88 Began planting tobacco in lower strip of CLM field.

04-25-88 Completed planting tobacco in lower strip of CLM field.

04-27-88 Completed planting tobacco in CLM field.

05-05-88 Completed planting tobacco in SLM field. 


\section{APPENDIX 1. Log of Farming Activities at the Row-Crop Basins, 1984-90, Guilford County, North Carolina-Continued}

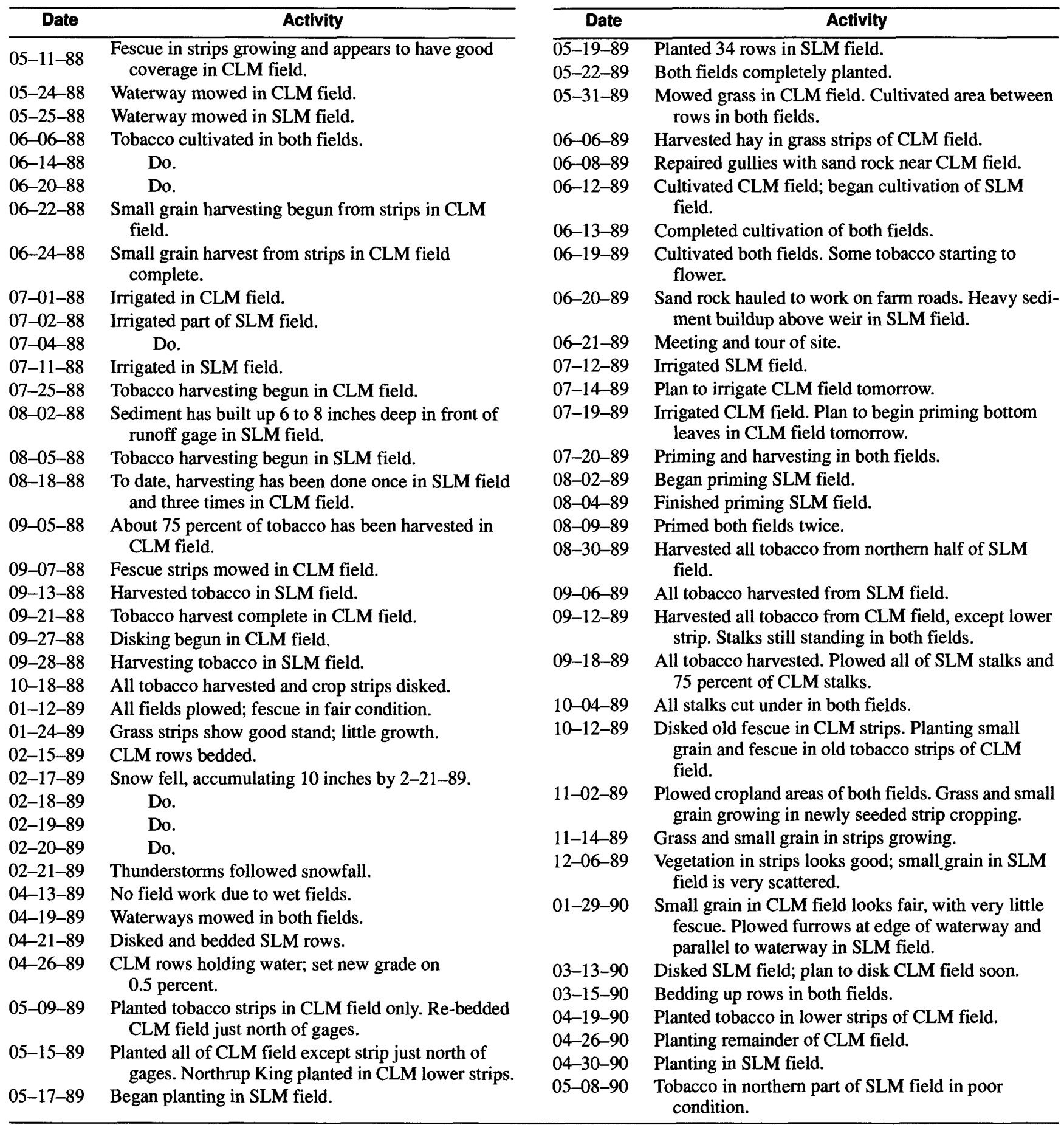




\section{APPENDIX 2A. Log of Chemical and Fertilizer Applications at the Row-Crop Basins in Guilford County, North Carolina, in 1985}

[Abbreviations used in appendix 2A-F are listed below. Source: John Andrews, Guilford County Soil and Water Conservation District, written commun., 1985]

\begin{tabular}{|c|c|c|c|c|c|}
\hline Date & $\begin{array}{l}\text { Chemical trade } \\
\text { name or fertilizer }{ }^{1}\end{array}$ & $\begin{array}{l}\text { Application } \\
\text { rate }\end{array}$ & Basin & $\begin{array}{c}\text { Total area } \\
\text { treated (acres) }\end{array}$ & Total applied \\
\hline \multicolumn{6}{|c|}{ Chemical application } \\
\hline $3-18$ & Ridomil & $1 \mathrm{qt} / \mathrm{ac}$ & SLM & 4.8 & $4.8 \mathrm{qts}$ \\
\hline \multirow[t]{3}{*}{$4-23$} & Enide & $2 \mathrm{lbs} / \mathrm{ac}$ & Both & 7.8 & $15.6 \mathrm{lbs}$ \\
\hline & Orthene & $2 \mathrm{lbs} / \mathrm{ac}$ & Both & 7.8 & $15.6 \mathrm{lbs}$ \\
\hline & Ridomil & $\mathrm{l} \mathrm{qt} / \mathrm{ac}$ & Both & 7.8 & $7.8 \mathrm{qts}$ \\
\hline \multirow[t]{2}{*}{$6-10$} & Orthene & $2 \mathrm{lbs} / \mathrm{ac}$ & CLM & 3 & lbs \\
\hline & Sevimol & $1 \mathrm{qt} / \mathrm{ac}$ & CLM & 3 & 3 qts \\
\hline \multirow[t]{2}{*}{$6-18$} & Sevimol & $1 \mathrm{qt} / \mathrm{ac}$ & CLM & 3 & qts \\
\hline & Enide & $4 \mathrm{lbs} / \mathrm{ac}$ & CLM & 3 & 12 lbs \\
\hline $6-19$ & Dipel & $1 \mathrm{lb} / \mathrm{ac}$ & Both & 7.8 & $7.8 \mathrm{lbs}$ \\
\hline \multirow[t]{2}{*}{$7-15$} & Sevimol & $1 \mathrm{qt} / \mathrm{ac}$ & CLM & 3 & 3 qts \\
\hline & Prime + & By hand & CLM & 3 & 1.5 gals est. \\
\hline $7-19$ & Prime + & By hand & SLM & 4.8 & 3 gals est. \\
\hline \multirow[t]{3}{*}{$7-22$} & Orthene & l lb/ac & SLM & 4.8 & $4.8 \mathrm{lbs}$ \\
\hline & Malathion & $\mathrm{l} \mathrm{pt} / \mathrm{ac}$ & SLM & 4.8 & $4.8 \mathrm{pts}$ \\
\hline & Lannate & $1 \mathrm{pt} / \mathrm{ac}$ & SLM & 4.8 & $4.8 \mathrm{pts}$ \\
\hline $7-29$ & Prime + & By hand & CLM & 3 & 1.5 gals est. \\
\hline \multirow[t]{4}{*}{$8-02$} & Parathion & $1 \mathrm{qt} / \mathrm{ac}$ & Upper both & 5 & qts \\
\hline & Super Sucker Stuff & By hand & Upper both & 5 & gals est. \\
\hline & Malathion & $1 \mathrm{pt} / \mathrm{ac}$ & Upper both & 5 & pts \\
\hline & Orthene & $1 \mathrm{lb} / \mathrm{ac}$ & Upper both & 5 & 5 lbs \\
\hline \multirow[t]{2}{*}{$8-22$} & Orthene & $1 \mathrm{lb} / \mathrm{ac}$ & Both & 7.8 & $7.8 \mathrm{lbs}$ \\
\hline & Nudrin & $1.5 \mathrm{pts} / \mathrm{ac}$ & Both & 7.8 & $11.7 \mathrm{pts}$ \\
\hline \multicolumn{6}{|c|}{ Fertilizer application } \\
\hline $4-23$ & $8-16-24$ & $700 \quad \mathrm{lbs} / \mathrm{ac}$ & Both & 7.8 & $5,460 \quad$ lbs \\
\hline $5-28$ & $15-0-14$ & $200 \mathrm{lbs} / \mathrm{ac}$ & Both & 7.8 & $1,560 \quad$ lbs \\
\hline $6-14$ & $8-16-24$ & $200 \mathrm{lbs} / \mathrm{ac}$ & SLM & 4.8 & 960 lbs \\
\hline
\end{tabular}

${ }^{1}$ Fertilizer numbers indicate ratio of nitrogen, phosphorus, and potassium.

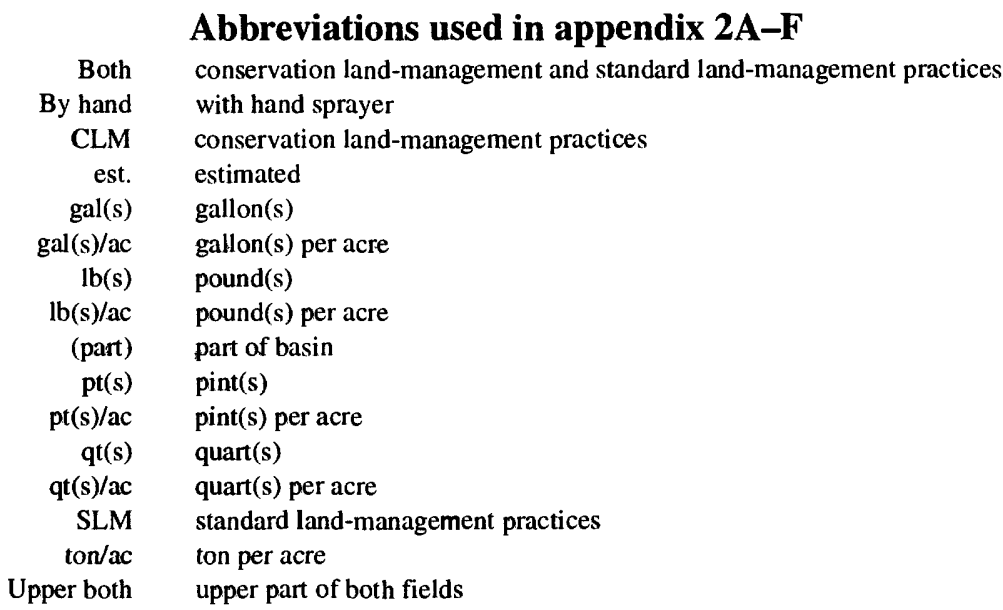




\section{APPENDIX 2B. Log of Chemical and Fertilizer Applications at the Row-Crop Basins in Guilford County, North Carolina, in 1986}

[Abbreviations used in appendix 2A-F are on page 46. Source: John Andrews, Guilford County Soil and Water Conservation District, written commun., 1986]

\begin{tabular}{|c|c|c|c|c|c|c|c|}
\hline Date & $\begin{array}{l}\text { Chemical trade } \\
\text { name or fertilizer }\end{array}$ & $\begin{array}{r}\text { Appll } \\
\text { ra }\end{array}$ & $\begin{array}{l}\text { Ication } \\
\text { te }\end{array}$ & Basin & $\begin{array}{c}\text { Total area } \\
\text { treated (acres) }\end{array}$ & \multicolumn{2}{|c|}{ Total applied } \\
\hline \multicolumn{8}{|c|}{ Chemical application } \\
\hline$\overline{4-01}$ & Ridomil & 2 & $\mathrm{qts} / \mathrm{ac}$ & SLM & 4.8 & 9.6 & qts \\
\hline \multirow[t]{2}{*}{$5-05$} & Enide & 2 & $\mathrm{lbs} / \mathrm{ac}$ & Both & 8.5 & 17 & lbs \\
\hline & Orthene & 2 & $\mathrm{lbs} / \mathrm{ac}$ & Both & 8.5 & 11 & lbs \\
\hline $6-10$ & Dipel & 1 & $\mathrm{lb} / \mathrm{ac}$ & Both & 8.5 & 8.5 & lbs \\
\hline $6-23$ & Sevimol & 1.5 & $\mathrm{qts} / \mathrm{ac}$ & CLM & 3.7 & 5.6 & qts \\
\hline \multirow{2}{*}{$7-02$} & Enide & 2.2 & $\mathrm{lbs} / \mathrm{ac}$ & Both & 8.5 & 18.7 & lbs \\
\hline & Prime + & By h & land & Both & 8.5 (part) & .5 & qt est. \\
\hline \multirow[t]{3}{*}{$7-11$} & Sevimol & 1 & $\mathrm{qt} / \mathrm{ac}$ & CLM & 3.7 & 3.7 & qts \\
\hline & Orthene & 1 & $\mathrm{lb} / \mathrm{ac}$ & CLM & 3.7 & 3.71 & lbs \\
\hline & Malathion & 1 & $\mathrm{pt} / \mathrm{ac}$ & CLM & 3.7 & 3.7 & pts \\
\hline $7-23$ & Prime + & By $h$ & land & SLM & 4.8 & 2.5 & gals est. \\
\hline \multirow[t]{4}{*}{$7-29$} & Orthene & 2 & $\mathrm{lbs} / \mathrm{ac}$ & CLM & 3.7 & 7.4 & lbs \\
\hline & Vydate L & .5 & $\mathrm{qt} / \mathrm{ac}$ & CLM & 3.7 & 1.8 & qts \\
\hline & Nudrin & 1 & $\mathrm{pt} / \mathrm{ac}$ & CLM & 3.7 & 3.7 & pts \\
\hline & Malathion & 1 & $\mathrm{pt} / \mathrm{ac}$ & CLM & 3.7 & 3.7 & pts \\
\hline \multirow[t]{4}{*}{$7-30$} & Orthene & 2 & $\mathrm{lbs} / \mathrm{ac}$ & SLM & 4.8 & 9.6 & lbs \\
\hline & Wydate L & .5 & $\mathrm{qt} / \mathrm{ac}$ & SLM & 4.8 & 2.4 & qts \\
\hline & Nudrin & 1 & $\mathrm{pt} / \mathrm{ac}$ & SLM & 4.8 & 4.8 & pts \\
\hline & Malathion & 1 & $\mathrm{pt} / \mathrm{ac}$ & SLM & 4.8 & 4.8 & pts \\
\hline $9-09$ & Ethrel & 1 & $\mathrm{gal} / \mathrm{ac}$ & CLM & 3.7 & 3.7 & gals \\
\hline $9-24$ & Ethrel & 1 & $\mathrm{gal} / \mathrm{ac}$ & CLM & 2 (part) & 2 & gals \\
\hline \multicolumn{8}{|c|}{ Fertilizer application } \\
\hline $2-15$ & $33-0-0$ & 300 & $\mathrm{lbs} / \mathrm{ac}$ & CLM & 3.7 & 1,110 & $\begin{array}{l}\text { lbs (waterways and } \\
\text { grass strips only) }\end{array}$ \\
\hline $5-05$ & $8-16-24$ & 700 & $\mathrm{lbs} / \mathrm{ac}$ & Both & 8.5 & 5,950 & lbs \\
\hline $5-23$ & $8-0-24$ & 200 & $\mathrm{lbs} / \mathrm{ac}$ & Both & 8.5 & 1,700 & lbs \\
\hline
\end{tabular}

${ }^{1}$ Fertilizer numbers indicate ratio of nitrogen, phosphorus, and potassium. 
APPENDIX 2C. Log of Chemical and Fertilizer Applications at the Row-Crop Basins in Guilford County, North Carolina, in 1987

[Abbreviations used in appendix 2A-F are on page 46. Source: John Andrews, Guilford County Soil and Water Conservation District, written commun., 1987]

\begin{tabular}{|c|c|c|c|c|c|c|}
\hline Date & $\begin{array}{c}\text { Chemicai trade } \\
\text { name or fertillzer } 1\end{array}$ & $\begin{array}{l}\text { Appllcation } \\
\text { rate }\end{array}$ & Basin & $\begin{array}{c}\text { Total area } \\
\text { treated (acres) }\end{array}$ & & Total applied \\
\hline \multicolumn{7}{|c|}{ Chemical application } \\
\hline$\overline{5-07}$ & Ridomil & $2 \mathrm{qts} / \mathrm{ac}$ & Both & 8.5 & 17.0 & qts \\
\hline \multirow[t]{2}{*}{$5-11$} & Orthene & $2 \mathrm{lbs} / \mathrm{ac}$ & CLM & 3.7 & 7.4 & lbs \\
\hline & Enide & $2 \mathrm{lbs} / \mathrm{ac}$ & CLM & 3.7 & 7.4 & lbs \\
\hline \multirow[t]{2}{*}{$5-19$} & Orthene & $2 \mathrm{lbs} / \mathrm{ac}$ & SLM & 4.8 & 9.6 & lbs \\
\hline & Enide & $2 \mathrm{lbs} / \mathrm{ac}$ & SLM & 4.8 & 9.6 & lbs \\
\hline $7-08$ & Enide & $1 \mathrm{lb} / \mathrm{ac}$ & Both & 8.5 & 8.5 & lbs \\
\hline \multirow[t]{2}{*}{$7-14$} & Orthene & $1 \mathrm{lb} / \mathrm{ac}$ & Both & 8.5 & 8.5 & lbs \\
\hline & Lannate & 2 qts/ac & Both & 8.5 & 1.7 & qts \\
\hline $8-07$ & Prime + & By hand & Both & 8.5 & 4.5 & gals est. \\
\hline \multirow[t]{2}{*}{$8-08$} & Lannate & $1 \mathrm{qt} / \mathrm{ac}$ & Both & 8.5 & 8.5 & qts \\
\hline & Orthene & $1 \mathrm{lb} / \mathrm{ac}$ & Both & 8.5 & 8.5 & lbs \\
\hline \multirow[t]{2}{*}{$8-20$} & Orthene & $1 \mathrm{lb} / \mathrm{ac}$ & Both & 8.5 & 8.5 & lbs \\
\hline & Lannate & $2 \mathrm{qts} / \mathrm{ac}$ & Both & 8.5 & 1.7 & qts \\
\hline \multirow[t]{2}{*}{$8-27$} & Azodrin & $1 \mathrm{pt} / \mathrm{ac}$ & Both & 8.5 & 8.5 & pts \\
\hline & Orthene & $1 \mathrm{lb} / \mathrm{ac}$ & Both & 8.5 & 8.5 & lbs \\
\hline $9-03$ & Orthene & $2 \mathrm{lbs} / \mathrm{ac}$ & Both & 8.5 & 17 & lbs \\
\hline $9-03$ & Lannate & $1 \mathrm{qt} / \mathrm{ac}$ & Both & 8.5 & 8.5 & qts \\
\hline $9-19$ & Azodrin & $1 \mathrm{pt} / \mathrm{ac}$ & CLM & 3.7 & 3.7 & pts \\
\hline $9-19$ & Ethrel & $1 \mathrm{gal} / \mathrm{ac}$ & CLM & 3.7 & 3.7 & gals \\
\hline \multicolumn{7}{|c|}{ Fertilizer application } \\
\hline $1-14$ & $10-10-10$ & $220 \mathrm{lbs} / \mathrm{ac}$ & CLM & 3.7 & 814 & $\begin{array}{l}\text { lbs (waterways and } \\
\text { grass strips only) }\end{array}$ \\
\hline $5-11$ & $8-16-24$ & $800 \mathrm{lbs} / \mathrm{ac}$ & Both & 8.5 & 6,800 & lbs \\
\hline $5-19$ & $8-16-24$ & $800 \mathrm{lbs} / \mathrm{ac}$ & SLM & 4.8 & 3,840 & lbs \\
\hline $6-01$ & $16-0-0$ & $125 \mathrm{lbs} / \mathrm{ac}$ & Both & 8.5 & 1,062 & lbs \\
\hline \multirow[t]{2}{*}{$11-02$} & $10-10-10$ & $200 \mathrm{lbs} / \mathrm{ac}$ & Both & .5 & 100 & lbs (waterways only) \\
\hline & Lime & $800 \mathrm{lbs} / \mathrm{ac}$ & SLM & .5 & 400 & lbs (waterways only) \\
\hline
\end{tabular}

${ }^{1}$ Fertilizer numbers indicate ratio of nitrogen, phosphorus, and potassium. 
APPENDIX 2D. Log of Chemical and Fertilizer Applications at the Row-Crop Basins in Guilford County, North Carolina, in 1988

[Abbreviations used in appendix 2A-F are on page 46. Source: John Andrews, Guilford County Soil and Water Conservation District, written commun., 1988]

\begin{tabular}{|c|c|c|c|c|c|c|}
\hline Date & $\begin{array}{l}\text { Chemical trade } \\
\text { name or fertilizer } 1\end{array}$ & $\begin{array}{l}\text { Application } \\
\text { rate }\end{array}$ & Basin & $\begin{array}{c}\text { Total area } \\
\text { treated (acres) }\end{array}$ & & Total applled \\
\hline \multicolumn{7}{|c|}{ Chemical application } \\
\hline \multirow[t]{2}{*}{$4-22$} & Orthene & $2 \mathrm{lbs} / \mathrm{ac}$ & CLM & 3.7 & 7.4 & lbs \\
\hline & Enide & $2 \mathrm{lbs} / \mathrm{ac}$ & CLM & 3.7 & 7.4 & lbs \\
\hline \multirow[t]{2}{*}{$5-05$} & Orthene & $2 \mathrm{lbs} / \mathrm{ac}$ & SLM & 4.8 & 9.6 & lbs \\
\hline & Enide & $2 \quad \mathrm{lbs} / \mathrm{ac}$ & SLM & 4.8 & 9.6 & lbs \\
\hline $6-06$ & Orthene & $1.5 \mathrm{lbs} / \mathrm{ac}$ & CLM & 3.7 & 5.6 & lbs \\
\hline $6-09$ & Orthene & $1.5 \mathrm{lbs} / \mathrm{ac}$ & SLM & 4.8 & 7.2 & lbs \\
\hline $6-21$ & Prime + & By hand & SLM & 4.8 & 4 & gals est. \\
\hline \multirow[t]{3}{*}{$6-24$} & Sevimol & $1 \mathrm{pt} / \mathrm{ac}$ & CLM & 3.7 & 3.7 & pts \\
\hline & Orthene & $1 \mathrm{lb} / \mathrm{ac}$ & CLM & 3.7 & 3.7 & lbs \\
\hline & Azodrin & $1 \mathrm{qt} / \mathrm{ac}$ & CLM & 3.7 & 3.7 & qts \\
\hline \multirow[t]{4}{*}{$7-08$} & Sevimol & $1.5 \mathrm{pts} / \mathrm{ac}$ & CLM & 3.7 & 5.6 & lbs \\
\hline & Orthene & $1 \mathrm{lb} / \mathrm{ac}$ & CLM & 3.7 & 3.7 & lbs \\
\hline & Endocide + & $1 \mathrm{pt} / \mathrm{ac}$ & CLM & 3.7 & 3.7 & lbs \\
\hline & Prime + & Spilled & CLM & 3.7 & 1 & $\mathrm{qt}$ \\
\hline \multirow[t]{3}{*}{$7-19$} & Orthene & $1.5 \mathrm{lbs} / \mathrm{ac}$ & Both & 8.5 & 12.8 & lbs \\
\hline & Endocide & $1 \mathrm{pt} / \mathrm{ac}$ & Both & 8.5 & 8.5 & pts \\
\hline & Super Sucker Stuff & $1 \mathrm{gal} / \mathrm{ac}$ & CLM & 3.7 & 3.7 & gals \\
\hline $7-25$ & Prime + & $1 \mathrm{gal} / \mathrm{ac}$ & SLM & 4.8 & 2 & gals \\
\hline \multirow[t]{2}{*}{$7-29$} & Orthene & $1 \mathrm{lb} / \mathrm{ac}$ & SLM & 4.8 & 4.8 & lbs \\
\hline & Super Sucker Stuff & $1 \mathrm{gal} / \mathrm{ac}$ & SLM & 4.8 & 4.8 & gals \\
\hline $7-30$ & Prime + & By hand & SLM & 4.8 & 1 & gal est. \\
\hline $8-11$ & Endocide & $1 \mathrm{pt} / \mathrm{ac}$ & CLM & 3.7 & 3.7 & pts \\
\hline $8-12$ & Prime + & By hand & SLM & 4.8 & 1 & gal est. \\
\hline $8-31$ & Ethrel & $1 \mathrm{gal} / \mathrm{ac}$ & CLM & 1 (part) & 1 & gal \\
\hline $9-02$ & Ethrel & $1 \mathrm{gal} / \mathrm{ac}$ & CLM & 1.7 (part) & 1.7 & gals \\
\hline $9-28$ & Ethrel & $.5 \mathrm{gal} / \mathrm{ac}$ & SLM & 4.8 & 2.4 & gals \\
\hline \multicolumn{7}{|c|}{ Fertilizer application } \\
\hline \multirow[t]{4}{*}{$3-01$} & Lime & 1 ton/ac & SLM & 4.8 & 4.8 & tons \\
\hline & Lime & .5 ton/ac & CLM & 3.7 & 1.8 & tons \\
\hline & $0-46-0$ & $100 \mathrm{lbs} / \mathrm{ac}$ & Both & 8.5 & 850 & lbs (cropland only) \\
\hline & $34-0-0$ & $100 \mathrm{lbs} / \mathrm{ac}$ & Both & 3.9 & 390 & lbs (waterways only) \\
\hline $4-22$ & $6-12-18$ & $800 \mathrm{lbs} / \mathrm{ac}$ & CLM & 3.7 & 2,960 & lbs \\
\hline $5-05$ & $6-12-18$ & $800 \mathrm{lbs} / \mathrm{ac}$ & SLM & 4.8 & 3,840 & Ibs \\
\hline $5-16$ & $15-0-14$ & $200 \mathrm{lbs} / \mathrm{ac}$ & CLM & 3.7 & 740 & Ibs \\
\hline $5-23$ & $15-0-14$ & $200 \mathrm{lbs} / \mathrm{ac}$ & SLM & 4.8 & 960 & Ibs \\
\hline
\end{tabular}

${ }^{1}$ Fertilizer numbers indicate ratio of nitrogen, phosphorus, and potassium. 


\section{APPENDIX 2E. Log of chemical and fertilizer applications at the row-crop basins in Guilford County, North Carolina, in 1989}

[Abbreviations used in appendix 2A-F are on page 46. Source: John Andrews, Guilford County Soil and Water Conservation District, written commun., 1989]

\begin{tabular}{|c|c|c|c|c|c|c|c|}
\hline Date & $\begin{array}{l}\text { Chemical trade } \\
\text { name or fertliizer }{ }^{1}\end{array}$ & App & $\begin{array}{l}\text { lication } \\
\text { ate }\end{array}$ & Basin & $\begin{array}{c}\text { Total area } \\
\text { treated (acres) }\end{array}$ & Total a & applied \\
\hline & & & Chem & al applic & & & \\
\hline $4-20$ & Talone $\mathrm{C}-17$ & 8 & gals/ac & CLM & 3.7 & 29.6 & gals \\
\hline & Nemacur & 2 & gals/ac & SLM & 4.8 & 9.6 & gals \\
\hline & Lorsban & 2 & qts/ac & SLM & 4.8 & 9.6 & qts \\
\hline $5-04$ & Ridomil & 2 & gals/ac & CLM & 1.0 & 2.0 & gals \\
\hline & Nemacur & 2 & gals/ac & CLM & 1.0 & 2.0 & gals \\
\hline & Lorsban & 2 & $\mathrm{qts} / \mathrm{ac}$ & CLM & 1.0 & 2.0 & qts \\
\hline $5-08$ & Enide & 1.1 & $\mathrm{lbs} / \mathrm{ac}$ & CLM & 3.7 & 4.1 & lbs \\
\hline & Orthene & 1 & $\mathrm{lb} / \mathrm{ac}$ & CLM & 3.7 & 3.7 & lbs \\
\hline $5-17$ & Enide & 1.1 & $\mathrm{lbs} / \mathrm{ac}$ & SLM & 4.8 & 5.3 & lbs \\
\hline & Orthene & 2 & $\mathrm{lbs} / \mathrm{ac}$ & SLM & 4.8 & 9.6 & lbs \\
\hline $6-28$ & Orthene & 2 & $\mathrm{lbs} / \mathrm{ac}$ & Both & 8.5 & 17.0 & lbs \\
\hline & Endocide + & 2 & pts/ac & Both & 8.5 & 17.0 & pts \\
\hline $7-06$ & Prime + & & $y$ hand & SLM & 4.8 & 2.0 & gals \\
\hline & Prime + & & $y$ hand & CLM & 3.7 & 1.0 & gal \\
\hline $7-19$ & Orthene & 2 & $\mathrm{lbs} / \mathrm{ac}$ & SLM & 4.8 & 9.6 & lbs \\
\hline & Royal M.H. & 2 & gals/ac & SLM & 4.8 & 9.6 & gals \\
\hline $7-26$ & Lannate & 1.5 & $\mathrm{pts} / \mathrm{ac}$ & CLM & 3.7 & 5.6 & pts \\
\hline & Orthene & 2 & $\mathrm{lbs} / \mathrm{ac}$ & CLM & 3.7 & 7.4 & lbs \\
\hline & Fair + (M.H.) & 2 & gals/ac & CLM & 3.7 & 7.4 & gals \\
\hline $8-10$ & Orthene & 2 & $\mathrm{lbs} / \mathrm{ac}$ & CLM & 3.7 & 7.4 & lbs \\
\hline & Lannate & 1.5 & pts/ac & CLM & 3.7 & 5.6 & pts \\
\hline $8-23$ & Orthene & 2 & $\mathrm{lbs} / \mathrm{ac}$ & SLM & 4.8 & 9.6 & lbs \\
\hline & Lannate & 1.5 & $\mathrm{pts} / \mathrm{ac}$ & SLM & 4.8 & 7.2 & pts \\
\hline & Ethrel & 1 & $\mathrm{gal} / \mathrm{ac}$ & SLM & 2.0 & 2.0 & gals \\
\hline $8-24$ & Orthene & 2 & $\mathrm{lbs} / \mathrm{ac}$ & CLM & 3.7 & 7.4 & lbs \\
\hline & Endocide + & 1.5 & pts/ac & CLM & 3.7 & 5.6 & pts \\
\hline & Ethrel & 1 & $\mathrm{gal} / \mathrm{ac}$ & SLM & 2.8 & 2.8 & gals \\
\hline $9-06$ & Ethrel & 1 & $\mathrm{gal} / \mathrm{ac}$ & CLM & 3.7 & 3.7 & gals \\
\hline & & & Fertil & er applic & & & \\
\hline $2-15$ & $33-0-0$ & 200 & $\mathrm{lbs} / \mathrm{ac}$ & Both & 4.2 & 840 & lbs \\
\hline $5-08$ & $6-12-18$ & 580 & $\mathrm{lbs} / \mathrm{ac}$ & CLM & 3.7 & 2,146 & lbs \\
\hline $5-17$ & $6-12-18$ & 580 & $\mathrm{lbs} / \mathrm{ac}$ & SLM & 4.3 & 2,494 & lbs \\
\hline $5-31$ & $16-0-0$ & 125 & $\mathrm{lbs} / \mathrm{ac}$ & Both & 8.0 & 1,000 & lbs \\
\hline $6-12$ & $6-12-18$ & 40 & $\mathrm{lbs} / \mathrm{ac}$ & Both & 8.0 & 320 & lbs \\
\hline $10-12$ & $5-10-10$ & 250 & $\mathrm{lbs} / \mathrm{ac}$ & CLM & 3.7 & 925 & lbs \\
\hline
\end{tabular}

${ }^{1}$ Fertilizer numbers indicate ratio of nitrogen, phosphorus, and potassium. 


\section{APPENDIX 2F. Log of Chemical and Fertilizer Applications at the Row-Crop Basins in Guilford County, North Carolina, in 1990}

[Abbreviations used in appendix 2A-F are on page 46. Source: John Andrews, Guilford County Soil and Water Conservation District, written commun., 1990]

\begin{tabular}{|c|c|c|c|c|c|c|}
\hline Date & $\begin{array}{c}\text { Chemical trade } \\
\text { name or fertilizer }{ }^{1}\end{array}$ & $\begin{array}{c}\text { Appli } \\
\text { rat }\end{array}$ & $\begin{array}{l}\text { ication } \\
\text { te }\end{array}$ & Basin & $\begin{array}{c}\text { Total area } \\
\text { treated (acres) }\end{array}$ & Total applied \\
\hline & & & Chemic & applicat & & \\
\hline $3-14$ & Nemacur & 2 & gals/ac & Both & 8.0 & 16.0 gals \\
\hline & Lorsban & 1 & $\mathrm{pt} / \mathrm{ac}$ & Both & 8.0 & $8.0 \mathrm{pts}$ \\
\hline $4-19$ & Orthene & 1 & $\mathrm{lb} / \mathrm{ac}$ & CLM & 1.85 & $1.85 \mathrm{lbs}$ \\
\hline & Enide & 2.2 & $\mathrm{lbs} / \mathrm{ac}$ & CLM & 1.85 & $4.07 \mathrm{lbs}$ \\
\hline $4-26$ & Orthene & 1 & $\mathrm{lb} / \mathrm{ac}$ & CLM & 1.85 & $1.85 \mathrm{lbs}$ \\
\hline & Enide & 2.2 & $\mathrm{lbs} / \mathrm{ac}$ & CLM & 1.85 & $4.07 \mathrm{lbs}$ \\
\hline $4-30$ & Orthene & 1 & $\mathrm{lb} / \mathrm{ac}$ & SLM & .5 & $.5 \mathrm{lb}$ \\
\hline & Enide & 2.2 & $\mathrm{lbs} / \mathrm{ac}$ & SLM & .5 & $1.1 \mathrm{lbs}$ \\
\hline $6-06$ & Orthene & 1 & $\mathrm{lb} / \mathrm{ac}$ & CLM & 3.7 & $3.7 \mathrm{lbs}$ \\
\hline & Lannate & 1 & $\mathrm{pt} / \mathrm{ac}$ & CLM & 3.7 & $3.7 \mathrm{pts}$ \\
\hline $6-08$ & Endocide & .5 & $\mathrm{pt} / \mathrm{ac}$ & SLM & 4.3 & $2.15 \mathrm{pts}$ \\
\hline & Orthene & 1 & $\mathrm{lb} / \mathrm{ac}$ & SLM & 4.3 & $4.3 \mathrm{lbs}$ \\
\hline $7-03$ & Endocide + & 1.5 & $\mathrm{pts} / \mathrm{ac}$ & CLM & 3.7 & $5.55 \mathrm{pts}$ \\
\hline & Orthene & 1 & $\mathrm{lb} / \mathrm{ac}$ & CLM & 3.7 & $3.7 \mathrm{lbs}$ \\
\hline $7-21$ & Orthene & 1 & $\mathrm{lb} / \mathrm{ac}$ & Both & 8.0 & $8.0 \mathrm{lbs}$ \\
\hline & Endocide + & 1.5 & $\mathrm{pts} / \mathrm{ac}$ & Both & 8.0 & $12.0 \mathrm{pts}$ \\
\hline $8-17$ & Ethrel & .5 & $\mathrm{gal} / \mathrm{ac}$ & CLM & 3.7 & 1.85 gals \\
\hline & & & Fertilize & applicati & & \\
\hline $3-13$ & Lime & .5 & ton/ac & Both & 8.0 & tons \\
\hline $3-01$ & $0-10-10$ & 300 & $\mathrm{lbs} / \mathrm{ac}$ & CLM & .5 & 150 \\
\hline $3-14$ & $0-44-0$ & 300 & $\mathrm{lbs} / \mathrm{ac}$ & Both & 8.0 & 2,400 \\
\hline $4-19$ & $6-12-18$ & 600 & $\mathrm{lbs} / \mathrm{ac}$ & CLM & .25 & 150 \\
\hline $4-26$ & $6-12-18$ & 600 & $\mathrm{lbs} / \mathrm{ac}$ & CLM & .25 & 150 \\
\hline $4-30$ & $6-12-18$ & 600 & $\mathrm{lbs} / \mathrm{ac}$ & SLM & .5 & 300 \\
\hline $5-15$ & $15-0-14$ & 100 & $\mathrm{lbs} / \mathrm{ac}$ & Both & 8.0 & 800 \\
\hline $6-06$ & $8-16-24$ & 100 & $\mathrm{lbs} / \mathrm{ac}$ & SLM & 4.3 & 430 \\
\hline
\end{tabular}

${ }^{1}$ Fertilizer numbers indicate ratio of nitrogen, phosphorus, and potassium. 
APPENDIX 3. Probability Levels for the Wilcoxon Ranked Sum Test Comparisons Between Distributions of Physical WaterQuality Properties Measured in Surface Water at the Four Study Basins and Precipitation at Station 1, 1985-90, Guilford County, North Carolina

[SLM, standard land-management practices basin; CLM, conservation land-management practices basin; - , repeated result; ND, no data]

\begin{tabular}{llcccc}
\hline \multicolumn{1}{c}{ Basin } & Physical characteristic & $\begin{array}{c}\text { CLM } \\
\text { practices basin }\end{array}$ & $\begin{array}{c}\text { Mixed } \\
\text { land-use basin }\end{array}$ & Forested basin & Precipitation \\
\hline SLM .................... Specific conductance & 0.0001 & 0.86 & 0.0001 & 0.0001 \\
& $\mathrm{pH}$ & .022 & .0001 & .0008 & .0001 \\
& Dissolved solids & .632 & .0009 & .0007 & ND \\
& Specific conductance & - & .0001 & .3565 & .0001 \\
& $\mathrm{pH}$ & - & .0001 & .0308 & .0001 \\
& Dissolved solids & - & .0012 & .0007 & ND \\
Mixed land-use...... Specific conductance & - & - & .0001 & .0001 \\
& pH & - & - & .3014 & .0001 \\
& Dissolved solids & - & - & .4028 & ND \\
Forested.................. Specific conductance & - & - & - & .0001 \\
& pH & - & - & - & .0001 \\
& Dissolved solids & - & - & - & ND \\
\hline
\end{tabular}


APPENDIX 4. Probability Levels for the Wilcoxon Ranked Sum Test Comparisons Between Distributions of Nutrients Measured in Surface Water at the Four Study Basins and Precipitation at Station 1, 1985-90, Guilford County, North Carolina

[-, no data available, no comparison made, or duplicated in another column]

\begin{tabular}{|c|c|c|c|c|}
\hline Nutrients (by basin) & $\begin{array}{c}\text { Conservatlon } \\
\text { land- } \\
\text { management } \\
\text { practices basin }\end{array}$ & $\begin{array}{l}\text { Mixed } \\
\text { land-use } \\
\text { basin }\end{array}$ & $\begin{array}{c}\text { Forested } \\
\text { basin }\end{array}$ & Precipitation \\
\hline \multicolumn{5}{|l|}{ Standard land-management practices basin } \\
\hline 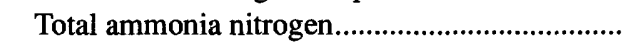 & 0.0034 & 0.27 & 0.0001 & 0.44 \\
\hline Total ammonia and organic nitrogen ................... & .39 & .36 & .0001 & .0001 \\
\hline 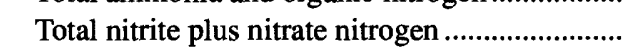 & .0024 & .02 & .0001 & .0019 \\
\hline 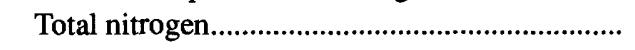 & .0004 & .0005 & .0001 & .0001 \\
\hline 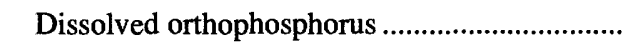 & .0001 & .0001 & .048 & .0002 \\
\hline Total phosphorus & .0012 & .062 & .0001 & .00010 \\
\hline Total potassium & .0001 & .0001 & .0001 & 一 \\
\hline \multicolumn{5}{|l|}{ Conservation land-management practices basin } \\
\hline 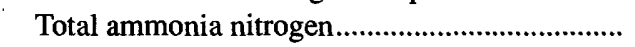 & - & .0002 & .0001 & .013 \\
\hline Total ammonia and organic nitrogen ................... & - & .92 & .0001 & .0001 \\
\hline Total nitrite plus nitrate nitrogen ......................... & - & .13 & .0001 & .16 \\
\hline Total nitrogen & - & .66 & .0001 & .0001 \\
\hline 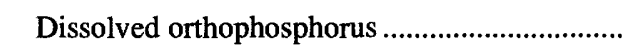 & - & .034 & .0001 & .0001 \\
\hline Total phosphorus & - & .12 & .0001 & .0001 \\
\hline Total potassium & - & .0026 & .0001 & - \\
\hline \multicolumn{5}{|l|}{ Mixed land-use basin } \\
\hline 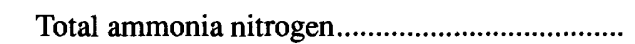 & - & - & .0001 & .81 \\
\hline Total ammonia and organic nitrogen .................. & - & - & .0001 & .0001 \\
\hline Total nitrite plus nitrate nitrogen ........................... & - & - & .0001 & .0028 \\
\hline 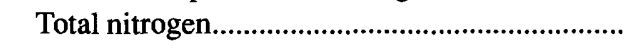 & - & - & .0001 & .0001 \\
\hline 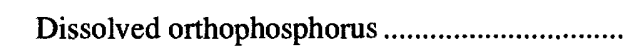 & - & - & .0001 & .0001 \\
\hline Total phosphorus & - & - & .0001 & .0001 \\
\hline 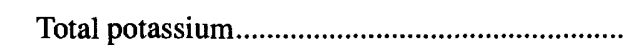 & - & - & .0001 & - \\
\hline \multicolumn{5}{|l|}{ Forested basin } \\
\hline 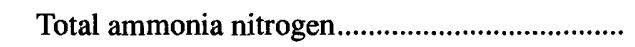 & - & - & - & .0001 \\
\hline Total ammonia and organic nitrogen .................... & - & - & - & .022 \\
\hline Total nitrite plus nitrate nitrogen ........................... & - & - & - & .0001 \\
\hline Total nitrogen & - & - & - & .87 \\
\hline 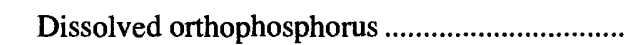 & - & - & - & .0001 \\
\hline Total phosphorus & - & - & - & .0001 \\
\hline 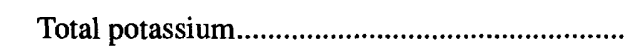 & - & - & - & - \\
\hline
\end{tabular}


APPENDIX 5. Probability Levels for the Wilcoxon Ranked Sum Test Comparisons Between Distributions of Nutrients Measured in Ground Water and Soil Water at the Two Row-Crop Basins, 1985-90, Guilford County, North Carolina

[-, no data available, no comparison made, or duplicated in another column. SLM, standard landmanagement practices basin; CLM, conservation land-management practices basin]

\begin{tabular}{|c|c|c|c|}
\hline \multirow{2}{*}{ Nutrients (by basin) } & \multirow{2}{*}{$\frac{\text { SLM }}{\text { Ground water }}$} & \multicolumn{2}{|c|}{ CLM } \\
\hline & & Soil water & Ground water \\
\hline \multicolumn{4}{|l|}{$\overline{\text { SLM-Soil water }}$} \\
\hline Total ammonia and organic nitrogen ......... & 0.041 & 0.93 & 0.12 \\
\hline Total nitrite plus nitrate nitrogen ............... & .65 & .0017 & .23 \\
\hline 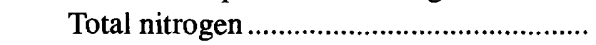 & .23 & .0072 & .02 \\
\hline \multicolumn{4}{|l|}{ SLM-Ground water } \\
\hline Total ammonia and organic nitrogen ......... & - & .03 & .31 \\
\hline Total nitrite plus nitrate nitrogen ................ & - & .0011 & .17 \\
\hline Total nitrogen & - & .72 & .61 \\
\hline \multicolumn{4}{|l|}{ CLM-Soil water } \\
\hline Total ammonia and organic nitrogen ......... & - & - & .083 \\
\hline Total nitrite plus nitrate nitrogen ............... & - & - & .080 \\
\hline 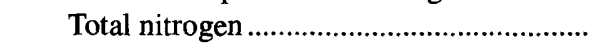 & - & - & .077 \\
\hline
\end{tabular}

\section{APPENDIX 6. Probability Levels for the Wilcoxon Ranked Sum Test Comparisons Between Distributions of Nutrients Measured in Surface Water at the Two Row-Crop Basins and Nutrients Measured in Ground Water and Soil Water at the Two Row-Crop Basins, 1985-90, Guilford County, North Carolina}

[-, no data available or no comparison made]

\begin{tabular}{|c|c|c|}
\hline Nutrients (by basin) & $\begin{array}{l}\text { Surface water } \\
\text { compared to } \\
\text { ground water }\end{array}$ & $\begin{array}{l}\text { Surface water } \\
\text { compared to soil } \\
\text { water }\end{array}$ \\
\hline \multicolumn{3}{|l|}{ Standard land-management practices basin } \\
\hline $\begin{array}{l}\text { Total ammonia nitrogen } \\
\text { Total ammonia and organic nitrogen } \\
\text { Total nitrite plus nitrate nitrogen } \\
\text { Total nitrogen }\end{array}$ & $\begin{array}{r}0.0001 \\
.0001 \\
.0207 \\
.0001\end{array}$ & $\begin{array}{r}0.0001 \\
.0001 \\
.0400 \\
.0001\end{array}$ \\
\hline 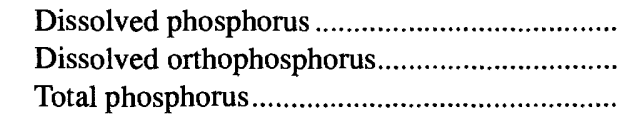 & $\begin{array}{l}.0001 \\
.0001 \\
.0001\end{array}$ & $\begin{array}{l}- \\
.0001 \\
.0001\end{array}$ \\
\hline Total potassium & .0214 & .0055 \\
\hline \multicolumn{3}{|l|}{ Conservation land-management practices basin } \\
\hline $\begin{array}{l}\text { Total ammonia nitrogen } \\
\text { Total ammonia and organic nitrogen } \\
\text { Total nitrite plus nitrate nitrogen } \\
\text { Total nitrogen }\end{array}$ & $\begin{array}{l}.0001 \\
.0001 \\
.0345 \\
.0001\end{array}$ & $\begin{array}{l}.0001 \\
.0001 \\
.0001 \\
.0001\end{array}$ \\
\hline 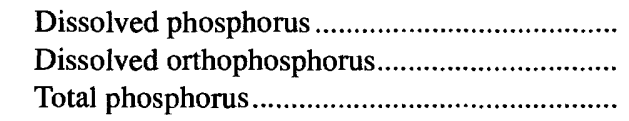 & $\begin{array}{l}.0001 \\
.0001 \\
.0001\end{array}$ & $\begin{array}{l}- \\
.0001 \\
.0001\end{array}$ \\
\hline Total potassium & - & - \\
\hline
\end{tabular}




\section{APPENDIX 7. Probability Levels for the Wilcoxon Ranked Sum Test Comparisons Between Distributions of Nutrients Measured in Soil-Water Samples From Lysimeters at 3-, 6-, and 9-foot Depths at the Two Row-Crop Basins, 1985-90, Guilford County, North Carolina}

[-, no data available, no comparison made, or duplicated in another column. SLM, standard landmanagement practices basin; CLM, conservation land-management practices basin]

\begin{tabular}{|c|c|c|c|c|c|}
\hline \multirow{2}{*}{ Nutrients (by basin) } & \multicolumn{2}{|c|}{ SLM lysimeters } & \multicolumn{3}{|c|}{ CLM lysimeters } \\
\hline & 6 feet & 9 feet & 3 feet & 6 feet & 9 feet \\
\hline \multicolumn{6}{|c|}{ SLM } \\
\hline \multicolumn{6}{|l|}{ Lysimeters at 3-foot depth } \\
\hline Total ammonia nitrogen .................................. & 0.09 & 0.0001 & 0.89 & - & - \\
\hline Total ammonia and organic nitrogen ....... & .02 & .0005 & .46 & - & - \\
\hline Total nitrite plus nitrate nitrogen ............... & .10 & .40 & .03 & - & - \\
\hline Dissolved orthophosphorus .......................... & .06 & .040 & .99 & - & - \\
\hline Total phosphorus........................................... & .0001 & .0007 & .22 & - & - \\
\hline \multicolumn{6}{|l|}{ Lysimeters at 6-foot depth } \\
\hline Total ammonia nitrogen .................................. & - & .0017 & - & 0.21 & - \\
\hline Total ammonia and organic nitrogen ....... & - & .023 & - & .10 & - \\
\hline Total nitrite plus nitrate nitrogen ............. & - & .83 & - & .33 & - \\
\hline Dissolved orthophosphorus ........................... & - & .27 & - & .32 & - \\
\hline 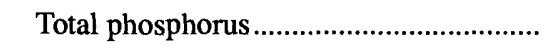 & - & .06 & - & .08 & - \\
\hline \multicolumn{6}{|l|}{ Lysimeters at 9-foot depth } \\
\hline Total ammonia nitrogen ................................. & - & - & - & - & 0.06 \\
\hline Total ammonia and organic nitrogen ....... & - & - & - & - & .83 \\
\hline Total nitrite plus nitrate nitrogen .............. & - & - & - & - & .12 \\
\hline Dissolved orthophosphorus ........................... & - & - & - & - & .29 \\
\hline 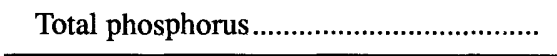 & - & - & - & - & .89 \\
\hline \multicolumn{6}{|c|}{ CLM } \\
\hline \multicolumn{6}{|l|}{ Lysimeters at 3-foot depth } \\
\hline Total ammonia nitrogen ................................. & - & - & - & .058 & .0003 \\
\hline Total ammonia and organic nitrogen ....... & - & - & - & .011 & .0084 \\
\hline Total nitrite plus nitrate nitrogen .............. & - & - & - & .52 & .93 \\
\hline Dissolved orthophosphorus ........................... & - & - & - & .075 & .0012 \\
\hline 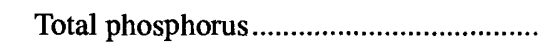 & - & - & - & .0043 & .0011 \\
\hline \multicolumn{6}{|l|}{ Lysimeters at 6-foot depth } \\
\hline Total ammonia nitrogen ................................. & - & - & - & - & .03 \\
\hline Total ammonia and organic nitrogen ....... & - & - & - & - & .90 \\
\hline Total nitrite plus nitrate nitrogen .............. & - & - & - & - & .82 \\
\hline Dissolved orthophosphorus .......................... & - & - & - & - & .24 \\
\hline Total phosphorus............................................. & - & - & - & - & - \\
\hline
\end{tabular}




\section{APPENDIX 8. Pesticide Concentrations in Surface Water at the Forested Basin, 1985-90, Guilford County, North Carolina}

[Pesticide analyses during 1985-88 were performed by the Research Triangle Institute laboratory, Research Triangle Park, N.C. Analyses during 1989-90 were performed by the U.S. Geological Survey National Water-Quality Laboratory, Arvada, Colo. Concentrations are in micrograms per liter. $\mathrm{ft}^{3} / \mathrm{s}$, square foot per second; <, less than]

\begin{tabular}{|c|c|c|c|c|c|c|c|c|c|}
\hline Date & $\begin{array}{c}\text { instantaneous } \\
\text { discharge } \\
\left(\mathrm{ft}^{3} / \mathbf{s}\right)\end{array}$ & $\begin{array}{l}\text { Acephate } \\
\text { (Orthene, } \\
\text { insectlcide) }\end{array}$ & $\begin{array}{l}\text { Ethoprop } \\
\text { (Mocap, } \\
\text { insecticide) }\end{array}$ & $\begin{array}{c}\text { Metalaxyl } \\
\text { (Ridomil 2E, } \\
\text { fungiclde) }\end{array}$ & $\begin{array}{l}\text { Diphenamid } \\
\text { (Enid 90W, } \\
\text { herbicide) }\end{array}$ & $\begin{array}{l}\text { Isopropalin } \\
\text { (Paarlan, } \\
\text { herbicide) }\end{array}$ & $\begin{array}{l}\text { Fenamiphos } \\
\text { (Nemacur, } \\
\text { insecticlde) }\end{array}$ & $\begin{array}{c}\text { Flumetralin } \\
\text { (Prime +, } \\
\text { growth } \\
\text { reguiator) }\end{array}$ & $\begin{array}{c}\text { Napropamlde } \\
\text { (Davrinoi 2E, } \\
\text { herbicide) }\end{array}$ \\
\hline $5-20-86$ & 0.15 & $<0.5$ & $<0.05$ & $<0.5$ & $<0.13$ & $<0.005$ & $<2.5$ & $<0.005$ & $<0.25$ \\
\hline $7-23-87$ & .02 & $<.5$ & $<.05$ & $<.5$ & $<.13$ & $<.005$ & $<2.5$ & $<.005$ & $<.25$ \\
\hline $9-07-87$ & .03 & $<.5$ & $<.05$ & $<.5$ & $<.13$ & $<.005$ & $<2.5$ & $<.005$ & $<.25$ \\
\hline $6-03-89$ & .03 & $<.1$ & $<.02$ & $<.1$ & $<.02$ & $<.02$ & $<.1$ & $<.02$ & $<.1$ \\
\hline $6-21-89$ & .28 & $<.1$ & $<.02$ & $<.1$ & $<.02$ & $<.02$ & $<.1$ & $<.02$ & $<.1$ \\
\hline
\end{tabular}

\section{APPENDIX 9. Pesticide Concentrations in Surface Water at the Mixed Land-Use Basin, 1985-90, Guilford County, North Carolina}

[Pesticide analyses during 1985-88 were performed by the Research Triangle Institute laboratory, Research Triangle Park, N.C. Analyses during 1989-90 were performed by the U.S. Geological Survey National Water-Quality Laboratory, Arvada, Colo. Concentrations are in micrograms per liter. $\mathrm{ft}^{3} / \mathrm{s}$, square foot per second; <, less than; - , no data available]

\begin{tabular}{|c|c|c|c|c|c|c|c|c|c|}
\hline Date & $\begin{array}{c}\text { Instantaneous } \\
\text { dlscharge } \\
\left(\mathrm{ft}^{3} / \mathrm{s}\right)\end{array}$ & $\begin{array}{l}\text { Acephate } \\
\text { (Orthene, } \\
\text { insecticlde) }\end{array}$ & $\begin{array}{l}\text { Ethoprop } \\
\text { (Mocap, } \\
\text { insecticlde) }\end{array}$ & $\begin{array}{c}\text { Metalaxyl } \\
\text { (Ridomii 2E, } \\
\text { funglcide) }\end{array}$ & $\begin{array}{l}\text { Diphenamld } \\
\text { (Enid 90w, } \\
\text { herbicide) }\end{array}$ & $\begin{array}{c}\text { isopropaiin } \\
\text { (Paarlan, } \\
\text { herbicide) }\end{array}$ & $\begin{array}{l}\text { Fenamiphos } \\
\text { (Nemacur, } \\
\text { insectlcide) }\end{array}$ & $\begin{array}{c}\text { Flumetralin } \\
\text { (Prime +, } \\
\text { growth } \\
\text { regulator) }\end{array}$ & $\begin{array}{c}\text { Napropamide } \\
\text { (Davrinoi 2E, } \\
\text { herbicide) }\end{array}$ \\
\hline $5-20-86$ & 0.47 & $<0.5$ & $<0.05$ & $<0.5$ & $<0.13$ & $<0.005$ & $<2.5$ & $<0.005$ & $<0.25$ \\
\hline $7-23-87$ & .08 & $<.5$ & $<.05$ & $<.5$ & $<.13$ & $<.005$ & $<2.5$ & $<.005$ & $<.25$ \\
\hline $9-07-87$ & .20 & $<.5$ & $<.05$ & $<.5$ & $<.13$ & $<.005$ & $<2.5$ & $<.005$ & $<.25$ \\
\hline $7-13-88$ & .87 & $<.5$ & $<.05$ & $<.5$ & $<.13$ & $<.005$ & $<2.5$ & - & $<.25$ \\
\hline $5-05-89$ & 7.8 & $<.1$ & $<.02$ & .3 & detected & $<.02$ & $<.1$ & $<.02$ & $<.1$ \\
\hline $5-05-89$ & 11 & $<.1$ & $<.02$ & .3 & $<.02$ & $<.02$ & $<.1$ & $<.02$ & .2 \\
\hline $6-05-89$ & 5.2 & $<.1$ & $<.02$ & 1 & .1 & $<.02$ & $<.1$ & $<.02$ & .25 \\
\hline $6-05-89$ & 4.4 & $<.1$ & $<.02$ & .7 & .1 & $<.02$ & $<.1$ & $<.02$ & .3 \\
\hline
\end{tabular}




\section{APPENDIX 10. Pesticide Concentrations in Surface Water at the Standard Land- Management Practices Basin, 1985-90, Guilford County, North Carolina}

[Pesticide analyses during 1985-88 were performed by the Research Triangle Institute laboratory, Research Triangle Park, N.C. Analyses during 1989-90 were performed by the U.S. Geological Survey National Water-Quality Laboratory, Arvada, Colo. Concentrations are in micrograms per liter. $\mathrm{ft}^{3} / \mathrm{s}$, square foot per second; <, less than; -, no data available]

\begin{tabular}{|c|c|c|c|c|c|c|c|c|c|}
\hline Date & $\begin{array}{c}\text { Instantaneous } \\
\text { discharge } \\
\left(\mathrm{ft}^{3} / \mathrm{s}\right)\end{array}$ & $\begin{array}{l}\text { Acephate } \\
\text { (Orthene, } \\
\text { insecticide) }\end{array}$ & $\begin{array}{l}\text { Ethoprop } \\
\text { (Mocap, } \\
\text { insecticide) }\end{array}$ & $\begin{array}{c}\text { Metalaxyl } \\
\text { (Ridomil 2E, } \\
\text { fungicide) }\end{array}$ & $\begin{array}{l}\text { Diphenamid } \\
\text { (Enid 90W, } \\
\text { herbicide) }\end{array}$ & $\begin{array}{l}\text { Isopropalin } \\
\text { (Paarlan, } \\
\text { herbicide) }\end{array}$ & $\begin{array}{l}\text { Fenamlphos } \\
\text { (Nemacur, } \\
\text { insecticide) }\end{array}$ & $\begin{array}{c}\text { Flumetralin } \\
\text { (Prime +, } \\
\text { growth } \\
\text { regulator) }\end{array}$ & $\begin{array}{c}\text { Napropamide } \\
\text { (Devrinol 2E, } \\
\text { herbicide) }\end{array}$ \\
\hline $5-20-86$ & 6.0 & $<0.5$ & $<0.05$ & 10 & $<0.13$ & $<0.005$ & $<2.5$ & 0.20 & $<0.25$ \\
\hline $7-02-86$ & .85 & $<.5$ & $<.05$ & 14 & $<.13$ & $<.005$ & $<2.5$ & $<.005$ & $<.25$ \\
\hline $8-11-86$ & 18.7 & $<.5$ & $<.05$ & 3.9 & 9.6 & $<.005$ & $<2.5$ & .74 & $<.25$ \\
\hline $9-07-87$ & .32 & $<.5$ & 1.92 & $<.5$ & $<.13$ & $<.005$ & $<2.5$ & .86 & $<.25$ \\
\hline $9-07-87$ & 3.49 & $<.5$ & 3.19 & $<.5$ & $<.13$ & $<.005$ & $<2.5$ & 1.25 & $<.25$ \\
\hline $7-09-88$ & - & $<.5$ & $<.05$ & $<.5$ & $<.13$ & $<.005$ & $<2.5$ & $<.005$ & $<.25$ \\
\hline $7-13-88$ & 1.42 & $<.5$ & $<.05$ & $<.5$ & $<.13$ & $<.005$ & $<2.5$ & .38 & $<.25$ \\
\hline $7-13-88$ & 1.92 & $<.5$ & $<.05$ & $<.5$ & $<.13$ & $<.005$ & $<2.5$ & .30 & $<.25$ \\
\hline $4-15-90$ & .002 & $<.1$ & $<.05$ & $<.02$ & .04 & $<.05$ & .25 & .06 & $<.05$ \\
\hline $4-15-90$ & .002 & $<.1$ & $<.05$ & .05 & .05 & $<.05$ & .16 & .06 & $<.05$ \\
\hline $5-02-90$ & 15 & .7 & $<.05$ & $<.2$ & 36 & $<.05$ & .20 & .07 & $<.05$ \\
\hline $5-02-90$ & .526 & .25 & $<.05$ & .1 & 26.2 & $<.05$ & .20 & .06 & $<.05$ \\
\hline $7-13-90$ & .280 & $<.1$ & $<.05$ & .09 & .04 & $<.05$ & .10 & .7 & $<.05$ \\
\hline $7-13-90$ & .413 & $<.1$ & $<.05$ & .08 & .04 & $<.05$ & $<.10$ & 1.0 & $<.05$ \\
\hline $7-13-90$ & 4.185 & $<.1$ & $<.05$ & .07 & .03 & $<.05$ & $<.10$ & .8 & $<.05$ \\
\hline
\end{tabular}




\section{APPENDIX 11. Pesticide Concentrations in Surface Water at the Conservation Land- Management Practices Basin, 1985-90, Guilford County, North Carolina}

[Pesticide analyses during 1985-88 were performed by the Research Triangle Institute laboratory, Research Triangle Park, N.C. Analyses during 1989-90 were performed by the U.S. Geological Survey National Water-Quality Laboratory, Arvada, Colo. Concentrations are in micrograms per liter. $\mathrm{ft}^{3} / \mathrm{s}$, square foot per second; <, less than; --, no data available]

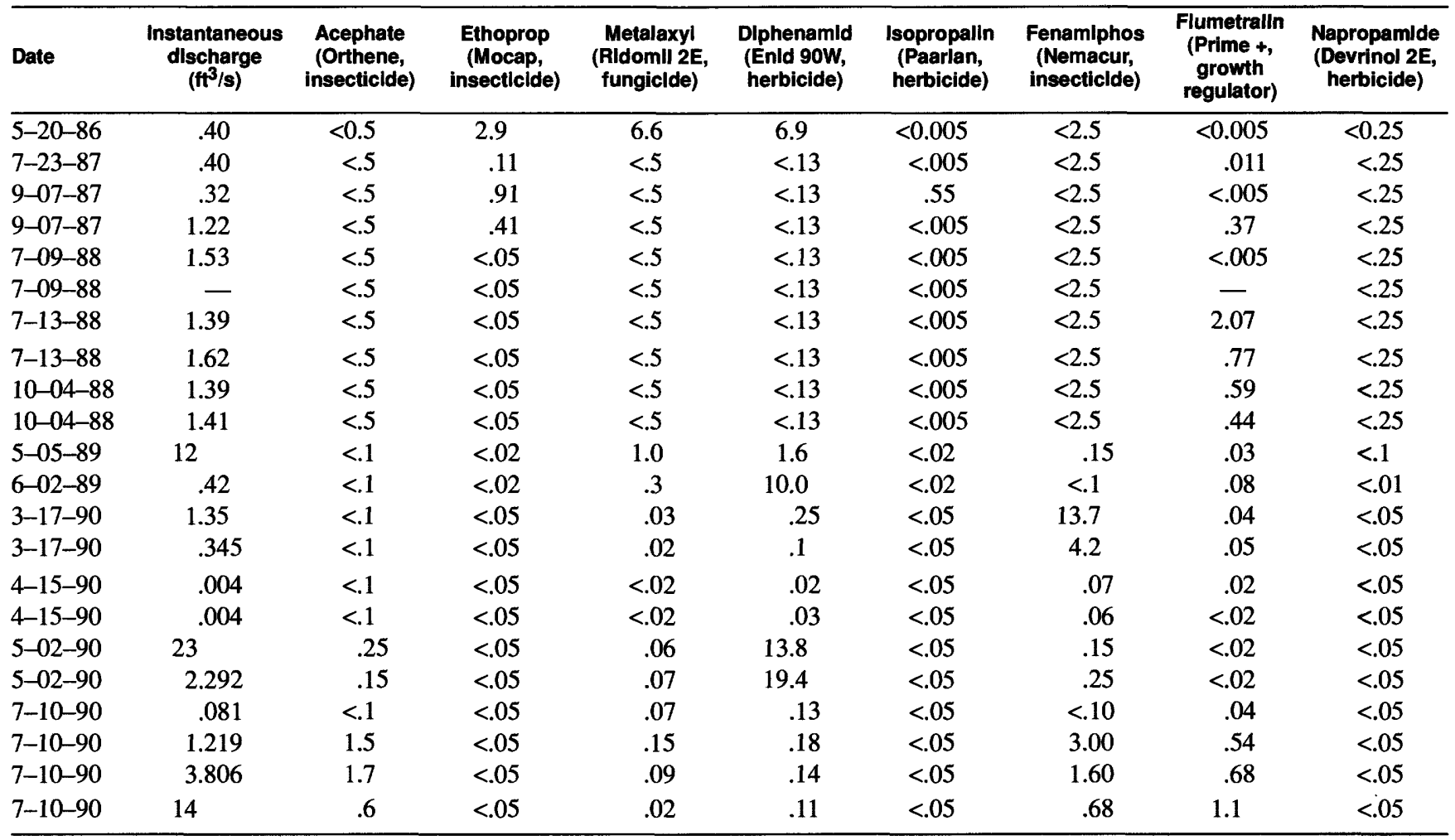




\section{APPENDIX 12. Pesticide Concentrations in Ground Water from Well 101 and Soil Samples Nearby, Conservation Land-Management Practices Basin, 1985-90, Guilford County, North Carolina}

[Pesticide analyses during 1985-88 were performed by the Research Triangle Institute laboratory, Research Triangle Park, N.C. Analyses during 1989-90 were performed by the U.S. Geological Survey National Water-Quality Laboratory, Arvada, Colo. Concentrations are in micrograms per liter for water samples and in micrograms per kilogram for soil samples. <, less than; - , no data available]

\begin{tabular}{|c|c|c|c|c|c|c|c|c|}
\hline Date & $\begin{array}{l}\text { Acephate } \\
\text { (Orthene, } \\
\text { insecticide) }\end{array}$ & $\begin{array}{l}\text { Ethoprop } \\
\text { (Mocap, } \\
\text { insecticide) }\end{array}$ & $\begin{array}{c}\text { Metalaxyl } \\
\text { (RidomII 2E, } \\
\text { funglcide) }\end{array}$ & $\begin{array}{l}\text { Diphenamid } \\
\text { (Enid 90W, } \\
\text { herbicide) }\end{array}$ & $\begin{array}{l}\text { Isopropaiin } \\
\text { (Paarlan, } \\
\text { herbicide) }\end{array}$ & $\begin{array}{l}\text { Fenamiphos } \\
\text { (Nemacur, } \\
\text { insectlcide) }\end{array}$ & $\begin{array}{c}\text { Flumetralln } \\
\text { (Prime +, growth } \\
\text { regulator) }\end{array}$ & $\begin{array}{l}\text { Napropamlde } \\
\text { (Devrlnol 2E, } \\
\text { herblclde) }\end{array}$ \\
\hline \multicolumn{9}{|c|}{ Water sample from well 101} \\
\hline $7-23-87$ & $<0.5$ & $<0.05$ & $<0.5$ & $<0.13$ & $<0.005$ & $<2.5$ & $<0.005$ & $<0.25$ \\
\hline \multicolumn{9}{|c|}{ Soil at 3-inch depth } \\
\hline $\begin{array}{l}3-09-87 \\
9-21-87\end{array}$ & $\begin{array}{l}<.5 \\
<.5\end{array}$ & $\begin{array}{r}6.3 \\
18.1\end{array}$ & $\begin{array}{l}<.5 \\
197\end{array}$ & $\begin{array}{l}<.13 \\
<.13\end{array}$ & $\begin{array}{c}.67 \\
<.005\end{array}$ & $\begin{array}{l}<2.5 \\
87\end{array}$ & $\begin{array}{r}2.0 \\
25.7\end{array}$ & $\begin{array}{l}17 \\
<.25\end{array}$ \\
\hline $3-28-88$ & $<.5$ & - & $<.5$ & $<.13$ & - & 42.5 & - & $<.25$ \\
\hline $6-26-89$ & $<4$ & 3.8 & 19 & 11 & $<.8$ & $<4$ & 5.1 & $<4$ \\
\hline $5-31-90$ & $<4$ & 2.4 & $<.8$ & 1.0 & .8 & $<4$ & $<.8$ & $<2$ \\
\hline \multicolumn{9}{|c|}{ Soil at 6-inch depth } \\
\hline $\begin{array}{l}3-09-87 \\
9-21-87\end{array}$ & $\begin{array}{l}<.5 \\
<.5\end{array}$ & $\begin{array}{r}5.3 \\
15.0\end{array}$ & 423 & $\begin{array}{l}<.13 \\
<.13\end{array}$ & $\begin{array}{l}1.8 \\
<.005\end{array}$ & $\begin{array}{l}<2.5 \\
250\end{array}$ & $\begin{array}{l}2.4 \\
9.5\end{array}$ & $\begin{array}{l}<.25 \\
<.25\end{array}$ \\
\hline $6-26-89$ & $<4$ & 3.6 & 14 & 6.9 & $<.8$ & $<4$ & 3.9 & $<4$ \\
\hline $5-31-90$ & $<4$ & 2.7 & $<.8$ & $<.8$ & $<2$ & $<4$ & $<.8$ & $<2$ \\
\hline \multicolumn{9}{|c|}{ Soil at 9-inch depth } \\
\hline $3-09-87$ & $<.5$ & 4.0 & $<.5$ & $<.13$ & .80 & $<2.5$ & .02 & $<.25$ \\
\hline $9-21-87$ & $<.5$ & $<.05$ & 310 & $<.13$ & $<.005$ & $<2.5$ & 23.8 & $<.25$ \\
\hline $3-28-88$ & $<.5$ & - & $<.5$ & $<.13$ & - & $<2.5$ & - & $<.25$ \\
\hline $6-26-89$ & $<4$ & $<.8$ & 5.1 & 4.2 & $<.8$ & $<4$ & $<.8$ & $<4$ \\
\hline $5-31-90$ & $<4$ & $<2$ & $<.8$ & $<.8$ & $<2$ & $<4$ & $<.8$ & $<2$ \\
\hline
\end{tabular}

\section{APPENDIX 13. Pesticide Concentrations in Soil Samples at Well 103, Conservation} Land-Management Practices Basin, 1985-90, Guilford County, North Carolina

[Pesticide analyses during 1985-88 were performed by the Research Triangle Institute laboratory, Research Triangle Park, N.C. Analyses during 1989-90 were performed by the U.S. Geological Survey National Water-Quality Laboratory, Arvada, Colo. Concentrations are in micrograms per kilogram. <, less than; -, no data available]

\begin{tabular}{|c|c|c|c|c|c|c|c|c|}
\hline Date & $\begin{array}{l}\text { Acephate } \\
\text { (Orthene, } \\
\text { insecticide) }\end{array}$ & $\begin{array}{l}\text { Ethoprop } \\
\text { (Mocap, } \\
\text { insecticide) }\end{array}$ & $\begin{array}{c}\text { Metalaxyi } \\
\text { (Ridomil 2E, } \\
\text { fungiclde) }\end{array}$ & $\begin{array}{l}\text { Diphenamid } \\
\text { (Enld 90W, } \\
\text { herbicide) }\end{array}$ & $\begin{array}{l}\text { Isopropalin } \\
\text { (Paarlan, } \\
\text { herbicide) }\end{array}$ & $\begin{array}{l}\text { Fenamlphos } \\
\text { (Nemacur, } \\
\text { insectlcide) }\end{array}$ & $\begin{array}{c}\text { Flumetralln } \\
\text { (Prime }+, \text { growth } \\
\text { regulator) }\end{array}$ & $\begin{array}{l}\text { Napropamlde } \\
\text { (Devrlnol 2E, } \\
\text { herbiclde) }\end{array}$ \\
\hline \multicolumn{9}{|c|}{ Soil at 3-inch depth } \\
\hline $3-09-87$ & $<0.5$ & 11 & $<0.5$ & $<0.13$ & $<0.005$ & $<2.5$ & 8.7 & 16 \\
\hline $9-21-87$ & $<.5$ & 14.5 & $<.5$ & $<.13$ & $<.005$ & 173 & 1.7 & 113 \\
\hline $3-28-88$ & $<.5$ & - & $<.5$ & $<.13$ & - & $<2.5$ & - & $<.25$ \\
\hline $10-26-89$ & $<.5$ & $<.05$ & $<.5$ & $<.13$ & $<.005$ & $<2.5$ & $<.005$ & $<.25$ \\
\hline $\begin{array}{l}6-26-89 \\
5-31-90\end{array}$ & $\begin{array}{l}19 \\
<4\end{array}$ & $\begin{array}{l}3.9 \\
26\end{array}$ & $\begin{array}{l}4.6 \\
4.2\end{array}$ & $\begin{array}{l}5.1 \\
7.9\end{array}$ & $<2$ & $\begin{aligned} & 5.6 \\
&<4\end{aligned}$ & $\begin{array}{l}300 \\
2.0\end{array}$ & $\begin{array}{l}<4 \\
<2\end{array}$ \\
\hline \multicolumn{9}{|c|}{ Soil at 6-inch depth } \\
\hline $3-09-87$ & $<.5$ & 27 & 15 & $<.13$ & $<.005$ & $<2.5$ & 5.0 & $<.25$ \\
\hline $9-21-87$ & $<.5$ & 11.0 & $<.5$ & $<.13$ & $<.005$ & 380 & $<.005$ & $<.25$ \\
\hline $6-26-89$ & 5.8 & $<.8$ & 3.6 & 4.3 & $<.8$ & $<4$ & 16 & $<4$ \\
\hline $5-31-90$ & $<4$ & 1.6 & $<.8$ & .8 & $<2$ & $<4$ & $<.8$ & $<2$ \\
\hline \multicolumn{9}{|c|}{ Soil at 9-inch depth } \\
\hline $3-09-87$ & $<.5$ & 13 & 12 & $<.13$ & .43 & $<2.5$ & .47 & $<.25$ \\
\hline $9-21-87$ & $<.5$ & 10.7 & $<.5$ & $<.13$ & $<.005$ & 867 & $<.005$ & 373 \\
\hline $3-28-88$ & $<.5$ & - & $<.5$ & $<.13$ & - & $<2.5$ & - & $<.25$ \\
\hline $6-26-89$ & 4.6 & $<.8$ & $<4$ & $<.8$ & $<.8$ & $<4$ & 4.1 & $<4$ \\
\hline $5-31-90$ & $<4$ & $<2$ & $<.8$ & $<.8$ & $<2$ & $<4$ & $<.8$ & $<2$ \\
\hline
\end{tabular}




\section{APPENDIX 14. Pesticide Concentrations in Soil Samples at Well 201, Standard Land- Management Practices Basin, 1985-90, Guilford County, North Carolina}

[Pesticide analyses during 1985-88 were performed by the Research Triangle Institute laboratory, Research Triangle Park, N.C. Analyses during 1989-90 were performed by the U.S. Geological Survey National Water-Quality Laboratory, Arvada, Colo. Concentrations are in micrograms per kilogram. <, less than; - , no data available]

\begin{tabular}{|c|c|c|c|c|c|c|c|c|}
\hline Date & $\begin{array}{l}\text { Acephate } \\
\text { (Orthene, } \\
\text { insecticlde) }\end{array}$ & $\begin{array}{l}\text { Ethoprop } \\
\text { (Mocap, } \\
\text { insectlclde) }\end{array}$ & $\begin{array}{c}\text { Metalaxyl } \\
\text { (Ridomil 2E, } \\
\text { fungicide) }\end{array}$ & $\begin{array}{c}\text { Diphenamid } \\
\text { (Enid 90w, } \\
\text { herbicide) }\end{array}$ & $\begin{array}{c}\text { Isopropalin } \\
\text { (Paarlan, } \\
\text { herbicide) }\end{array}$ & $\begin{array}{l}\text { Fenamiphos } \\
\text { (Nemacur, } \\
\text { insectlcide) }\end{array}$ & $\begin{array}{c}\text { Flumetralin } \\
\text { (Prime }+, \text { growth } \\
\text { regulator) }\end{array}$ & $\begin{array}{c}\text { Napropamide } \\
\text { (Devrlnol 2E, } \\
\text { herbicide) }\end{array}$ \\
\hline \multicolumn{9}{|c|}{ Soil at 3-inch depth } \\
\hline $9-21-87$ & $<.5$ & 15.0 & $<.5$ & $<.13$ & $<.005$ & $<2.5$ & $<.005$ & $<.25$ \\
\hline $3-28-88$ & $<.5$ & - & $<.5$ & $<.13$ & - & $<2.5$ & - & $<.25$ \\
\hline $10-26-88$ & $<.5$ & $<.05$ & $<.5$ & $<.13$ & $<.005$ & $<2.5$ & 3.5 & $<.25$ \\
\hline $5-31-90$ & $<4$ & 7.6 & 3.6 & 5.0 & 1.0 & $<4$ & 20 & $<2$ \\
\hline \multicolumn{9}{|c|}{ Soil at 6-inch depth } \\
\hline $3-09-87$ & $<.5$ & $<.05$ & 26 & $<.13$ & 1.6 & $<2.5$ & 50 & 10 \\
\hline $9-21-87$ & $<.5$ & 10.8 & 323 & $<.13$ & $<.005$ & 73 & 39.1 & $<.25$ \\
\hline $6-26-89$ & $<4$ & 4.0 & 4.4 & 4.9 & 2.2 & 3.8 & 4.4 & $<4$ \\
\hline $9-21-87$ & $<.5$ & $<.05$ & 500 & $<.13$ & $<.005$ & $<2.5$ & 41.4 & $<.25$ \\
\hline $3-28-88$ & $<.5$ & - & $<.5$ & $<.13$ & - & $<2.5$ & - & $<.25$ \\
\hline $10-26-88$ & $<.5$ & $<.05$ & $<.5$ & $<.13$ & $<.005$ & $<2.5$ & 1.5 & $<.25$ \\
\hline $6-26-89$ & $<4$ & $<.8$ & $<4$ & 4.0 & $<.8$ & $<4$ & 3.4 & $<4$ \\
\hline $5-31-90$ & $<4$ & $<2$ & $<.8$ & $<.8$ & $<2$ & $<4$ & $<.8$ & $<2$ \\
\hline
\end{tabular}

\section{APPENDIX 15. Pesticide Concentrations in Soil Samples at Well 206, Standard Land- Management Practices Basin, 1985-90, Guilford County, North Carolina}

[Pesticide analyses during 1985-88 were performed by the Research Triangle Institute laboratory, Research Triangle Park, N.C. Analyses during 1989-90 were performed by the U.S. Geological Survey National Water-Quality Laboratory, Arvada, Colo. Concentrations are in micrograms per kilogram. <, less than]

\begin{tabular}{|c|c|c|c|c|c|c|c|c|}
\hline Date & $\begin{array}{l}\text { Acephate } \\
\text { (Orthene, } \\
\text { Insecticide) }\end{array}$ & $\begin{array}{l}\text { Ethoprop } \\
\text { (Mocap, } \\
\text { Insecticide) }\end{array}$ & $\begin{array}{c}\text { Metalaxyl } \\
\text { (Ridomll 2E, } \\
\text { funglcide) }\end{array}$ & $\begin{array}{l}\text { Dlphenamid } \\
\text { (Enid 90W, } \\
\text { herbicide) }\end{array}$ & $\begin{array}{l}\text { Isopropalin } \\
\text { (Paarlan, } \\
\text { herblcide) }\end{array}$ & $\begin{array}{l}\text { Fenamiphos } \\
\text { (Nemacur, } \\
\text { Insecticide) }\end{array}$ & $\begin{array}{c}\text { Flumetralln } \\
\text { (Prime }+, \text { growth } \\
\text { regulator) }\end{array}$ & $\begin{array}{l}\text { Napropamlde } \\
\text { (Devrinol 2E, } \\
\text { herblcide) }\end{array}$ \\
\hline \multicolumn{9}{|c|}{ Soil at 3-inch depth } \\
\hline \multicolumn{9}{|c|}{ Soil at 6-inch depth } \\
\hline $9-21-87$ & $<.5$ & $<.05$ & 307 & $<.13$ & $<.005$ & $<2.5$ & 56.8 & $<.25$ \\
\hline \multicolumn{9}{|c|}{ Soil at 9-inch depth } \\
\hline $9-21-87$ & $<.5$ & $<.05$ & 303 & $<.13$ & $<.005$ & $<2.5$ & 29.6 & $<.25$ \\
\hline
\end{tabular}




\section{APPENDIX 16. Pesticide Concentrations In Soil Water at a Depth of 6 feet and Soil at Well 208, Standard Land-Management Practices Basin, 1985-90, Guilford County, North Carolina}

[Pesticide analyses during 1985-88 were performed by the Research Triangle Institute laboratory, Research Triangle Park, N.C. Analyses during 1989-90 were performed by the U.S. Geological Survey National Water-Quality Laboratory, Arvada, Colo. Concentrations are in micrograms per liter for water samples and micrograms per kilogram for soil samples; <, less than; - , no data available]

\begin{tabular}{|c|c|c|c|c|c|c|c|c|}
\hline Date & $\begin{array}{l}\text { Acephate } \\
\text { (Orthene, } \\
\text { insecticide) }\end{array}$ & $\begin{array}{c}\text { Ethoprop } \\
\text { (Mocap, } \\
\text { Insecticide) }\end{array}$ & $\begin{array}{c}\text { Metalaxyl } \\
\text { (Ridomil 2E, } \\
\text { fungicide) }\end{array}$ & $\begin{array}{l}\text { Diphenamid } \\
\text { (Enid 90W, } \\
\text { herbicide) }\end{array}$ & $\begin{array}{c}\text { Isopropalin } \\
\text { (Paarlan, } \\
\text { herbicide) }\end{array}$ & $\begin{array}{l}\text { Fenamiphos } \\
\text { (Nemacur, } \\
\text { Insectlcide) }\end{array}$ & $\begin{array}{c}\text { Flumetralin } \\
\text { (Prime +, growth } \\
\text { regulator) }\end{array}$ & $\begin{array}{c}\text { Napropamide } \\
\text { (Devrinol 2E, } \\
\text { herblcide) }\end{array}$ \\
\hline \multicolumn{9}{|c|}{ Soil water at 6-foot depth } \\
\hline $8-12-86$ & $<0.5$ & $<0.05$ & $<0.5$ & $<0.13$ & $<0.005$ & $<2.5$ & $<0.005$ & $<0.25$ \\
\hline $7-23-87$ & $<.5$ & $<.05$ & $<.5$ & $<.13$ & $<.005$ & $<2.5$ & $<.005$ & $<.25$ \\
\hline \multicolumn{9}{|c|}{ Soil at 3-inch depth } \\
\hline $3-09-87$ & $<.5$ & $<.05$ & 11 & $<.13$ & $<.005$ & $<2.5$ & 24 & 11 \\
\hline $3-28-88$ & $<.5$ & - & $<.5$ & $<.13$ & 一 & $<2.5$ & - & $<.25$ \\
\hline $6-26-89$ & 3.8 & 5.2 & 7.9 & 4.8 & 2.5 & $<4$ & 5.5 & $<4$ \\
\hline $5-31-90$ & $<4$ & 13 & 14 & 10 & 2.3 & $<4$ & 37 & $<2$ \\
\hline \multicolumn{9}{|c|}{ Soil at 6-inch depth } \\
\hline $3-09-87$ & $<.5$ & $<.05$ & 10 & $<.13$ & .90 & $<2.5$ & 35 & $<.25$ \\
\hline $6-26-89$ & $<4$ & 4.8 & 7.2 & 4.0 & 2.0 & $<4$ & 9.2 & $<4$ \\
\hline $5-31-90$ & $<4$ & 6.1 & 3.8 & 4.6 & 2.4 & $<4$ & 34 & $<2$ \\
\hline \multicolumn{9}{|c|}{ Soil at 9-inch depth } \\
\hline $3-09-87$ & $<.5$ & $<.05$ & $<.5$ & $<.13$ & $<.005$ & $<2.5$ & 14 & $<.25$ \\
\hline $3-28-88$ & .5 & - & $<.5$ & $<.13$ & 一 & $<2.5$ & - & $<.25$ \\
\hline $6-26-89$ & 3.7 & 9.8 & 3.5 & 4.4 & 3.5 & $<4$ & $<.8$ & $<4$ \\
\hline $5-31-90$ & $<4$ & 3.3 & .5 & 3.3 & 3.0 & $<4$ & .6 & $<2$ \\
\hline
\end{tabular}

\section{APPENDIX 17. Pesticide Concentrations in Ground Water from Well 107, Conservation Land-Management Practices Basin, 1985-90, Guilford County, North Carolina}

[Pesticide analyses during 1985-88 were performed by the Research Triangle Institute laboratory, Research Triangle Park, N.C. Analyses during 1989-90 were performed by the U.S. Geological Survey National Water-Quality Laboratory, Arvada, Colo. Concentrations are in micrograms per liter. <, less than]

\begin{tabular}{|c|c|c|c|c|c|c|c|c|}
\hline Date & $\begin{array}{l}\text { Acephate } \\
\text { (Orthene, } \\
\text { insecticide) }\end{array}$ & $\begin{array}{l}\text { Ethoprop } \\
\text { (Mocap, } \\
\text { insecticide) }\end{array}$ & $\begin{array}{c}\text { Metalaxyl } \\
\text { (Ridomil 2E, } \\
\text { fungicide) }\end{array}$ & $\begin{array}{l}\text { Diphenamid } \\
\text { (Enid 90W, } \\
\text { herblcide) }\end{array}$ & $\begin{array}{l}\text { Isopropalin } \\
\text { (Paarian, } \\
\text { herbicide) }\end{array}$ & $\begin{array}{l}\text { Fenamiphos } \\
\text { (Nemacur, } \\
\text { insecticide) }\end{array}$ & $\begin{array}{c}\text { Flumetralln } \\
\text { (Prime }+, \text { growth } \\
\text { regulator) }\end{array}$ & $\begin{array}{c}\text { Napropamide } \\
\text { (Devrinol 2E, } \\
\text { herblclde) }\end{array}$ \\
\hline $8-12-86$ & $<0.5$ & $<0.05$ & $<0.5$ & $<0.13$ & $<0.005$ & $<2.5$ & $<0.005$ & $<0.25$ \\
\hline $7-23-87$ & $<.5$ & $<.05$ & $<.5$ & $<.13$ & $<.005$ & $<2.5$ & $<.005$ & $<.25$ \\
\hline $9-07-87$ & $<.5$ & $<.05$ & $<.5$ & $<.13$ & $<.005$ & $<2.5$ & .05 & $<.25$ \\
\hline $7-09-88$ & $<.5$ & $<.05$ & $<.5$ & $<.13$ & $<.005$ & $<2.5$ & $<.005$ & $<.25$ \\
\hline $7-13-88$ & $<.5$ & $<.05$ & $<.5$ & $<.13$ & $<.005$ & $<2.5$ & $<.005$ & $<.25$ \\
\hline $10-04-88$ & $<.5$ & $<.05$ & $<.5$ & $<.13$ & $<.005$ & $<2.5$ & $<.005$ & $<.25$ \\
\hline $3-19-90$ & $<.1$ & $<.05$ & $<.02$ & $<.02$ & $<.05$ & .1 & $<.02$ & $<.05$ \\
\hline $4-11-90$ & $<.1$ & $<.05$ & $<.02$ & $<.02$ & $<.05$ & .6 & $<.02$ & $<.05$ \\
\hline $5-31-90$ & $<.1$ & $<.05$ & $<.02$ & 3.1 & $<.05$ & .07 & $<.02$ & $<.05$ \\
\hline $6-26-90$ & $<.1$ & $<.05$ & $<.02$ & 2.0 & $<.05$ & $<.10$ & $<.02$ & $<.05$ \\
\hline $7-19-90$ & $<.1$ & $<.05$ & $<.02$ & .14 & $<.05$ & $<.1$ & $<.02$ & $<.05$ \\
\hline $8-28-90$ & $<.1$ & $<.05$ & $<.02$ & .03 & $<.05$ & $<.1$ & $<.02$ & $<.05$ \\
\hline $9-25-90$ & $<.1$ & $<.05$ & $<.02$ & .02 & $<.05$ & $<.1$ & $<.02$ & $<.05$ \\
\hline
\end{tabular}




\section{APPENDIX 18. Pesticide Concentrations in Ground Water from Well 209, Standard Land-Management Practices Basin, 1985-90, Guilford County, North Carolina}

[Pesticide analyses during 1985-88 were performed by the Research Triangle Institute laboratory, Research Triangle Park, N.C. Analyses during 1989-90 were performed by the U.S. Geological Survey National Water-Quality Laboratory, Arvada, Colo. Concentrations are in micrograms per liter. <, less than]

\begin{tabular}{|c|c|c|c|c|c|c|c|c|}
\hline Date & $\begin{array}{l}\text { Acephate } \\
\text { (Orthene, } \\
\text { insecticide) }\end{array}$ & $\begin{array}{l}\text { Ethoprop } \\
\text { (Mocap, } \\
\text { insecticide) }\end{array}$ & $\begin{array}{c}\text { Metalaxyl } \\
\text { (Ridomil 2E, } \\
\text { fungicide) }\end{array}$ & $\begin{array}{l}\text { Diphenamid } \\
\text { (Enid 90w, } \\
\text { herbicide) }\end{array}$ & $\begin{array}{l}\text { Isopropalin } \\
\text { (Paarlan, } \\
\text { herbicide) }\end{array}$ & $\begin{array}{l}\text { Fenamiphos } \\
\text { (Nemacur, } \\
\text { insecticide) }\end{array}$ & $\begin{array}{c}\text { Flumetralin } \\
\text { (Prime +, growth } \\
\text { regulator) }\end{array}$ & $\begin{array}{c}\text { Napropamide } \\
\text { (Devrinol 2E, } \\
\text { herbicide) }\end{array}$ \\
\hline $8-12-86$ & $<0.5$ & $<0.05$ & $<0.5$ & 0.98 & $<0.0015$ & $<2.5$ & 0.0023 & $<0.25$ \\
\hline $7-23-87$ & $<.5$ & $<.05$ & $<.5$ & $<.13$ & $<.005$ & $<2.5$ & $<.005$ & $<.25$ \\
\hline $9-07-87$ & $<.5$ & $<.05$ & $<.5$ & $<.13$ & $<.005$ & $<2.5$ & $<.005$ & $<.25$ \\
\hline $7-09-88$ & $<.5$ & $<.05$ & $<.5$ & $<.13$ & $<.005$ & $<2.5$ & $<.005$ & $<.25$ \\
\hline $7-13-88$ & $<.5$ & $<.05$ & $<.5$ & $<.13$ & $<.005$ & $<2.5$ & $<.005$ & $<.25$ \\
\hline $10-04-88$ & $<.5$ & $<.05$ & $<.5$ & $<.13$ & $<.005$ & $<2.5$ & $<.005$ & $<.25$ \\
\hline $5-26-89$ & $<.1$ & $<.02$ & $<.1$ & detected & $<.02$ & detected & $<.02$ & $<.1$ \\
\hline $3-19-90$ & $<.1$ & $<.05$ & $<.02$ & $<.02$ & $<.05$ & .12 & $<.02$ & $<.05$ \\
\hline $4-11-90$ & $<.1$ & $<.05$ & $<.02$ & $<.02$ & $<.05$ & $<.10$ & $<.02$ & $<.05$ \\
\hline $5-31-90$ & $<.1$ & $<.05$ & .02 & .02 & $<.05$ & .05 & $<.02$ & $<.05$ \\
\hline $6-26-90$ & $<.1$ & $<.05$ & $<.02$ & $<.02$ & $<.05$ & $<.10$ & $<.02$ & $<.05$ \\
\hline $7-19-90$ & $<.1$ & $<.05$ & $<.02$ & .02 & $<.05$ & $<.1$ & $<.02$ & $<.05$ \\
\hline $8-28-90$ & $<.1$ & $<.05$ & $<.02$ & $<.02$ & $<.05$ & $<.1$ & $<.02$ & $<.05$ \\
\hline $9-25-90$ & $<.1$ & $<.05$ & $<.02$ & $<.02$ & $<.05$ & $<.1$ & $<.02$ & $<.05$ \\
\hline
\end{tabular}




\section{APPENDIX 19. Probability Levels for the Wilcoxon Ranked Sum Test Comparisons Between Distributions of Pesticide Concentrations Measured in Surface Water at the Four Study Basins and Soil at 3-, 6-, and 9-inch Depths at the Two Row-Crop Basins, 1985-90, Guilford County, North Carolina}

[SLM, standard land-management practices basin; CLM, conservation land-management practices basin; Mixed, mixed land-use basin; Forest, forested basin; GW, ground water; S3, soil at 3-inch depth; S6, soil at 6-inch depth; S9, soil at 9-inch depth; -, no data available, no comparison made, or duplicated in another column]

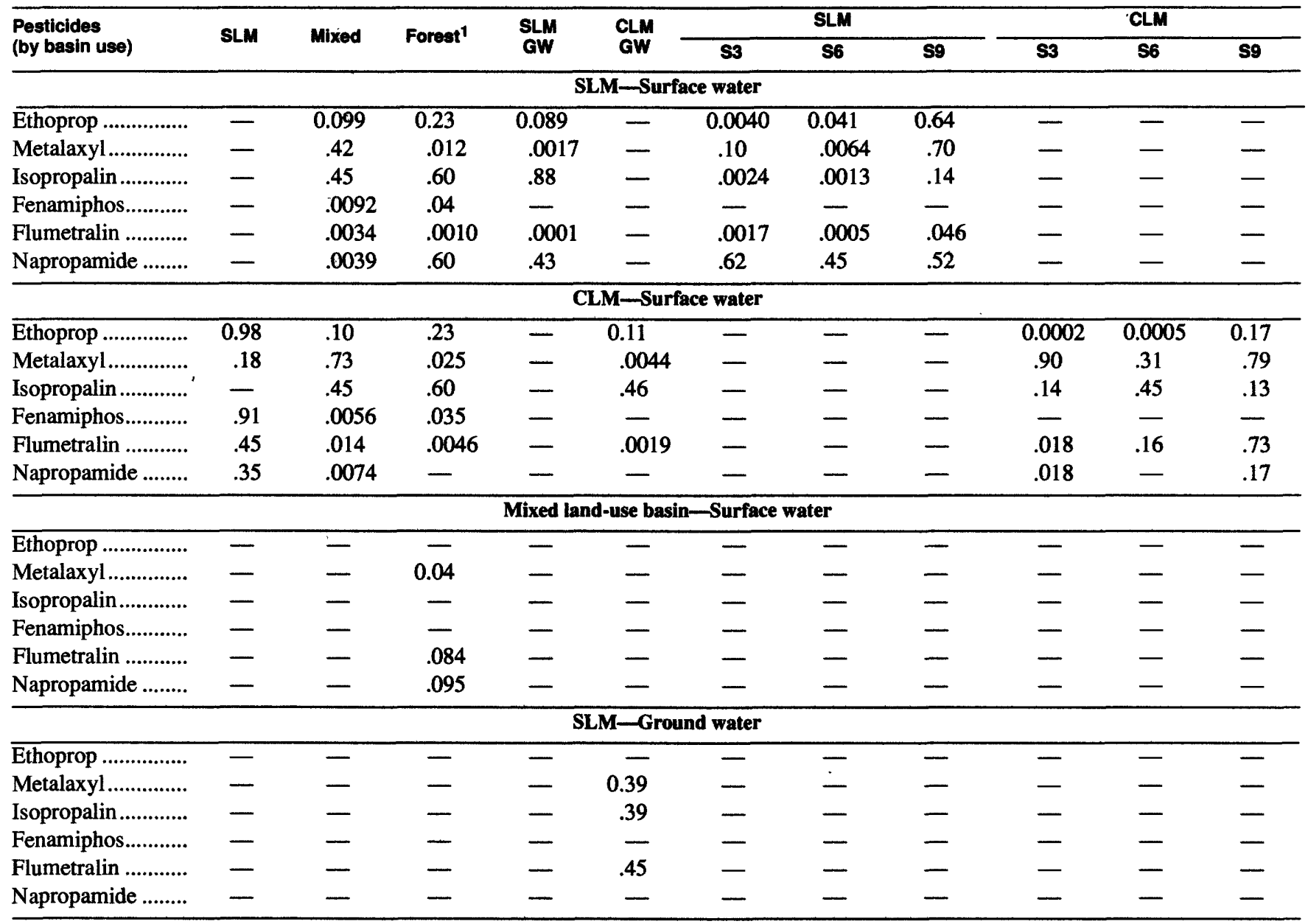

${ }^{1}$ No pesticides were detected in the forested basin; therefore, these probabilities represent a test for a difference from a concentration of zero. 
APPENDIX 20. Probability Levels for the Wilcoxon Ranked Sum Test Comparisons Between Distributions of Pesticide Concentrations Measured in Surface Water and Soil at All Depths at the Two Row-Crop Basins, 1985-90, Guilford County, North Carolina

[-, no data available, no comparison made, or duplicated in another column. SLM, standard land-management practices basin; CLM, conservation land-management practices basin]

\begin{tabular}{|c|c|c|}
\hline Pesticides (by basin use) & $\begin{array}{c}\text { SLM } \\
\text { (soll at all depths) }\end{array}$ & $\begin{array}{c}\mathrm{CLM} \\
\text { (soil at all depths) }\end{array}$ \\
\hline \multicolumn{3}{|c|}{ SLM-Surface water } \\
\hline Acephate .................................... & 0.83 & - \\
\hline 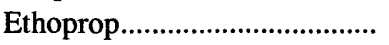 & .014 & - \\
\hline 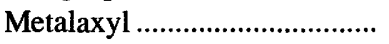 & .075 & - \\
\hline 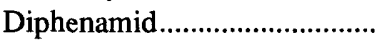 & .30 & - \\
\hline 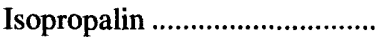 & .0019 & - \\
\hline 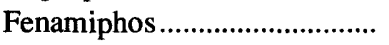 & .027 & - \\
\hline 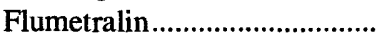 & .0001 & - \\
\hline 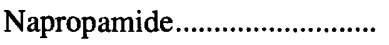 & .73 & - \\
\hline \multicolumn{3}{|c|}{ CLM-Surface water } \\
\hline Acephate ................................... & - & 0.35 \\
\hline 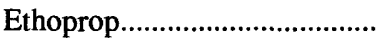 & - & .0001 \\
\hline 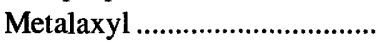 & - & .71 \\
\hline 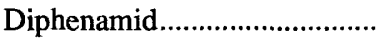 & - & .17 \\
\hline 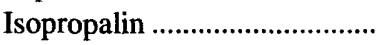 & - & .17 \\
\hline 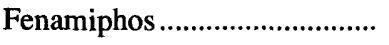 & - & .15 \\
\hline 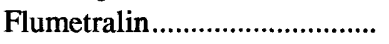 & - & .089 \\
\hline 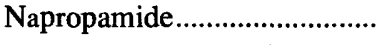 & - & .082 \\
\hline \multicolumn{3}{|c|}{ SLM-Soil at all depths } \\
\hline 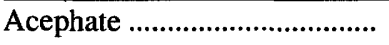 & - & .56 \\
\hline 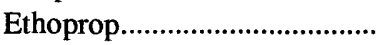 & - & .11 \\
\hline 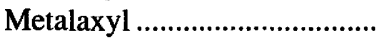 & - & .16 \\
\hline Diphenamid............................. & - & .52 \\
\hline 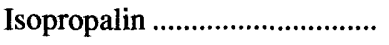 & - & .017 \\
\hline 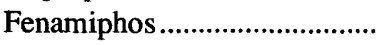 & - & .33 \\
\hline 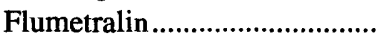 & - & .0058 \\
\hline 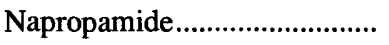 & - & .32 \\
\hline
\end{tabular}

APPENDIX 21. Probability Levels for the Wilcoxon Ranked Sum Test Comparisons Between Distributions of Pesticide Concentrations Measured in Soil at 3-, 6-, and 9-inch Depths at the Two Row-Crop Basins, 1985-90, Guilford County, North Carolina

[SLM, standard land-management practices basin; CLM, conservation land-management practices basin; S6, soil at 6-inch depth; S9, soil at 9inch depth; S3, soil at 3-inch depth; - , no data available, no comparison made, or duplicated in another column]

\begin{tabular}{|c|c|c|c|c|c|}
\hline \multirow{3}{*}{$\begin{array}{l}\text { Pestlcldes } \\
\text { (by basin) }\end{array}$} & \multicolumn{5}{|c|}{ Probability levels } \\
\hline & \multicolumn{2}{|c|}{ SLM } & \multicolumn{3}{|c|}{ CLM } \\
\hline & 56 & S9 & S3 & 56 & S9 \\
\hline \multicolumn{6}{|l|}{$\overline{\text { SLM-S3 }}$} \\
\hline Ethoprop ............. & 0.20 & 0.063 & 0.63 & 0.89 & 0.26 \\
\hline Flumetralin ........ & .37 & .15 & .20 & .041 & .030 \\
\hline \multicolumn{6}{|l|}{ SLM-S6 } \\
\hline Ethoprop ............. & - & .25 & .13 & .24 & .82 \\
\hline Flumetralin ........ & - & .055 & .11 & .039 & .011 \\
\hline \multicolumn{6}{|l|}{ SLM-S9 } \\
\hline Ethoprop............. & 一 & - & .014 & .027 & .42 \\
\hline Flumetralin ........ & - & - & .73 & .81 & .17 \\
\hline \multicolumn{6}{|l|}{ CLM-S3 } \\
\hline Ethoprop............ & - & - & - & .67 & .096 \\
\hline Flumetralin ........ & - & - & - & .74 & .15 \\
\hline \multicolumn{6}{|l|}{ CLM-S6 } \\
\hline Ethoprop............ & 一 & - & - & 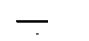 & .15 \\
\hline Flumetralin ........ & 一 & - & - & - & .49 \\
\hline
\end{tabular}

